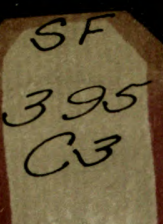

UC-NRLF

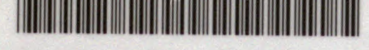

В 3894125 


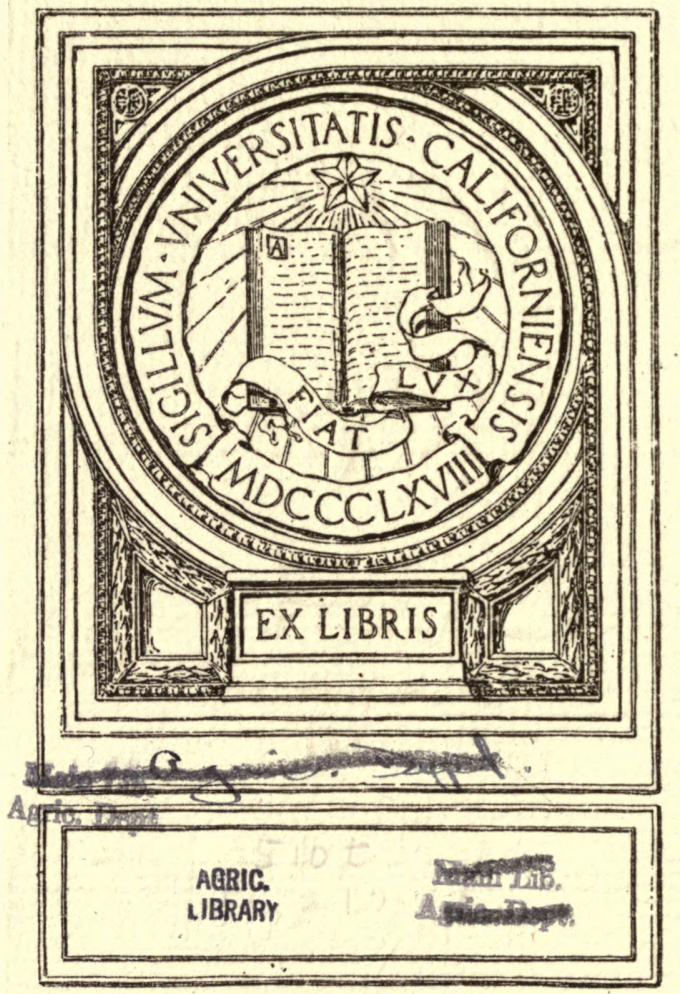














\section{DOMINION OF CANADA COLLEGE OF}

\section{DEPARTMENT OF AGRICULTURE}

Canada, Commission on the suine Ereeding industry of Denmark, Great I rear and Ireland

\section{SWINE HUSBANDRY}

IN THE

\section{UNITED KINGDOM AND DENMARK}

REPORT OF CANADIAN COMMISSION 1909 
$\rightarrow 595$

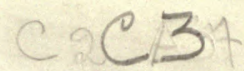

AGRIC.

LIBRADI

Main Lib.

Nario. Dept.

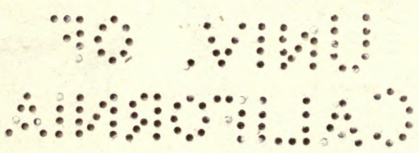


To the Honourable

Sydney A. Fisher,

Minister of Agriculture,

Ottawa.

SrR.-The Commission appointed by yourself to investigate and study the swine breeding industry of Denmark, Great Britain and Ireland, beg to make the following report:-

The Commission on arriving in England on June 27 spent a short time in London inquiring into the relative merits of the various classes of bacon that find sale in large quantities in the British market, and in securing as far as possible information that would be useful in the work of investigation. We then proceeded to Denmark where all phases of the swine rearing industry were carefully examined. From the 2 nd to the 17 th of July the time was spent in visiting farms of swine raisers, breeding centres, feeding stations, co-operative feed buying depots, co-operative and private bacon curing factories and live stock shows.

On the return journey to Great Britain we spent a short time in Holland looking into certain phases of pig raising as it would appear to come into competition with Canadian pork products.

A busy month was spent in Great Britain and Ireland, the time being chiefly occupied in visiting farms in districts where swine are reared in large numbers. In Scotland the cheese making sections in the western and southern counties were traversed. In Ireland the attention of the Commission was devoted principally to the central and south eastern districts where swine rearing is more or less common to every farm and where co-operative curing is commencing to obtain a foothold. In England the centres examined were the counties of Wiltshire, Berkshire and Suffolk, as well as a section of the Midlands. In each of the counties visited prominent breeding herds were inspected wherever opportunity offered without undue loss of time. The report presented represents the findings of the Commission based chiefly upon personal observations, inquiries and official reports of governmental departments charged with work having to do with the swine rearing industry.

The Commission are under deep obligation for the valuable assistance ungrudgingly bestowed upon us in each of the countries visited. In Denmark the services of the highest official of the government having to do with the swine industry were placed at our entire disposal. Statskonsulent Peter Aug. Morkeberg, who devotes his whole time to the swine and Red Danish cattle industries, mapped out and personally conducted the tour. Through the kindness of this officer interviews were secured with such leading authorities as Prof. Bernard Bang, the noted authority on tuberculosis; Prof. Hoffman Bang, director of the experiment station of animal and food products; Prof. Storch, at the head of the dairy department of the Royal Agricultural College at Copenhagen, and others more or less closely allied with the scientific side of Danish agriculture. The Commission wish to especially acknowledge the generosity shown by these busy men in providing information in regard to their work. Grateful acknowledgment has also to be made for the kindness shown by the managers of bacon factories, co-operative feed buying societies, feeding stations, agricul- 
tural shows, proprietors of swine breeding centres and general farmers called upon, each of whom not only gave freely of information but contributed as far as possible the proverbial hospitality of the Dane.

In Scotland the Commission was favoured with the personal guidance of Mr. James Dunlop of the Scottish Commission to Canada, as also Mr. Thomas Clement of the firm of Andrew Clement \& Sons, Commission Merchants, Glasgow, who accompanied us through the chief cheese making counties in which pig feeding is mainly carried on in Scotland. Gratitude is also due Prof. Wm. Stevenson for information respecting swine feeding tests conducted at the West of Scotland Dairy School, and the very many dairy farmers and their families, who contributed generously of their hospitality.

In Ireland the Department of Agriculture and Technical Instruction took charge of the Commission, placing at our disposal Mr. James Wood, who has charge of schemes of the Department for improving the breeds of swine and other stock. The members of the Commission are highly sensible of the kindness shown by the Department through their Secretary, Mr. Gill, as well as by the very many swine raisers, bacon curers and others who freely contributed to the comfort of the Commission and the work of investigation.

In England through the High Commissioner and the Board of Agriculture the way was opened for a careful study of the subject in hand. London commission men were eager to supply in every possible way useful information. Correspondents of the Board of Agriculture by invitation of the Secretary, Sir Thos. Elliott, wherever appealed to, assisted in locating swine raisers to be visited. In this regard valuable help must be acknowledged from the firm of Messrs. Harris \& Co., the veteran firm of Wiltshire bacon curers. Nor must the kindness of Mr. Wright of the Eastern Counties Farmers' Co-operative Association be forgotten. This officer, who handles about a thousand hogs per week, spent valuable time in conducting the Commission amongst swine raisers in the county of Suffolk. 'Then there were the breeders of pure bred herds among whom may be especially mentioned Mr. Sanders Spencer of Large Yorkshire fame, and Mr. C. F. Marriner a most successful breeder of Large Blacks, each of whom did their utmost by giving freely of their information and the hospitality of their homes.

The following pages contain the report of conditions bearing upon the swine rearing industry of Great Britain, Ireland, Denmark and Holland as discovered by the Commission, all of which is respectfully submitted.

We have the honour to be, Sir, your obedient servants,

W. W. Ballantyne, Chairman,

William Jones,

Gédéon Garcend,

Joseph RYE.

J. E. Sinclair,

J.'B. Spencer, Secretary and Editor. 


\section{CONTENTS.}

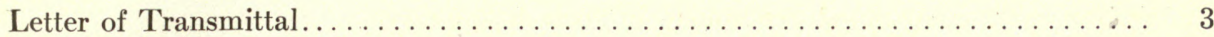



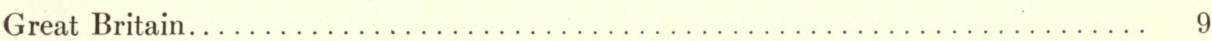



Pure Bred Herds................................ 10

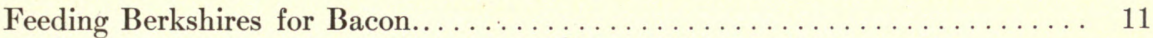

Harmony between Packer and Feeder...................... 12

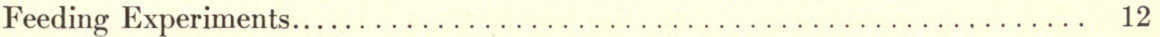

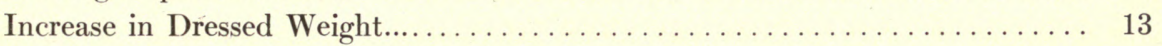

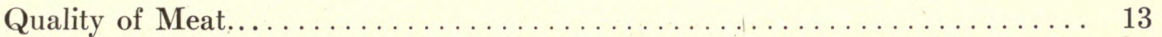

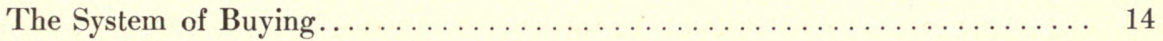

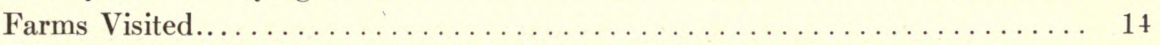

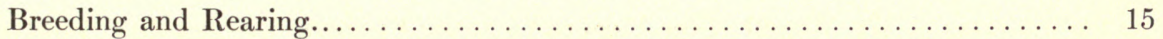

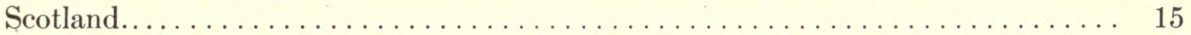

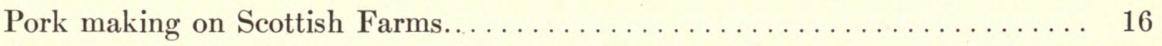

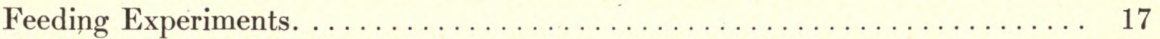

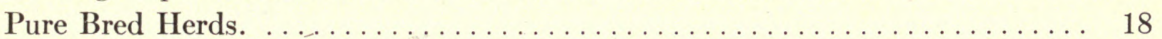

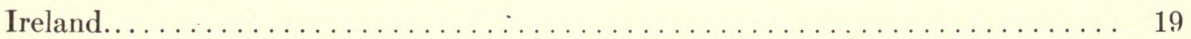

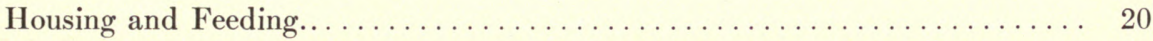

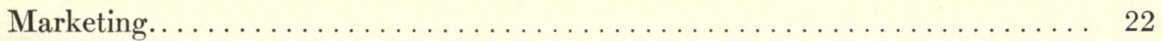

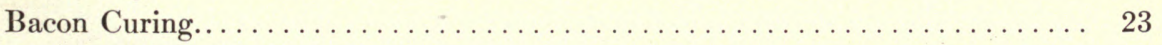

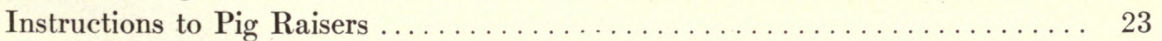

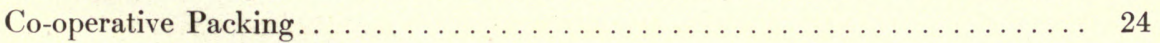

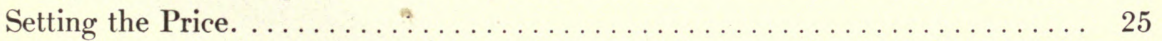

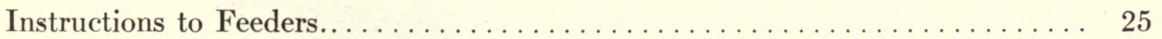

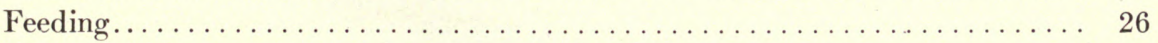

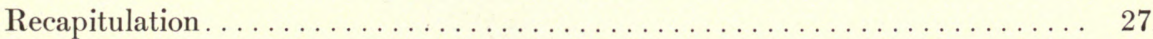

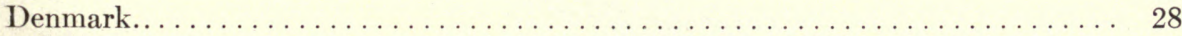

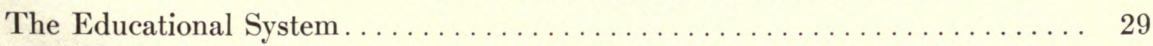

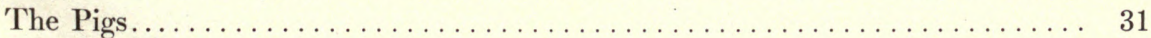

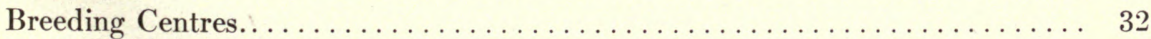

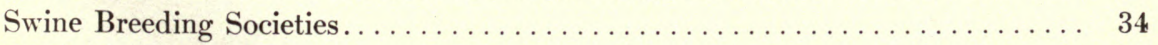

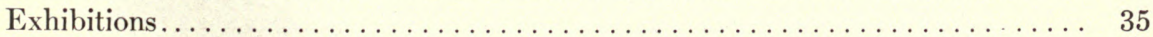


PAGe.

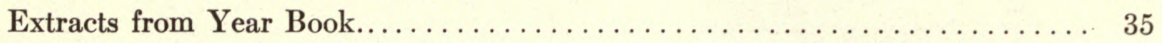

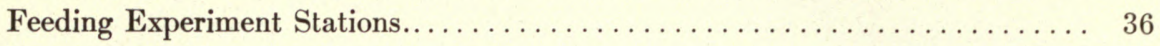

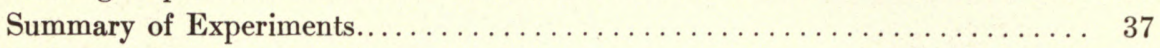

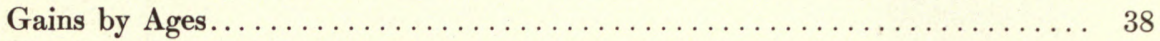

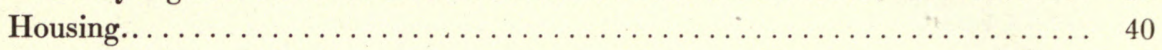

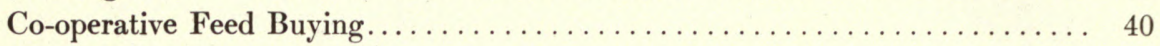

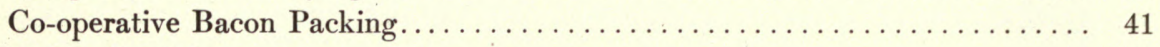

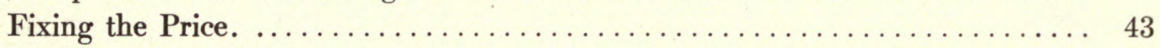

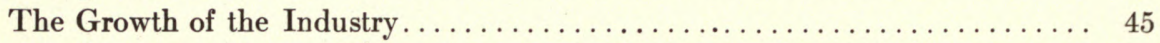

Prices paid for Pigs in Denmark and Canada................. 45

Transactions of one factory for 'Ten Years' $\ldots \ldots \ldots \ldots \ldots \ldots \ldots \ldots \ldots$

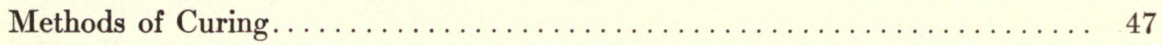

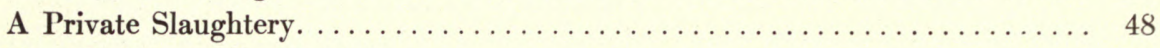

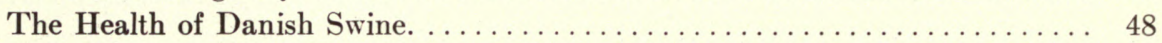

Conditions in Denmark reviewed....................... 49



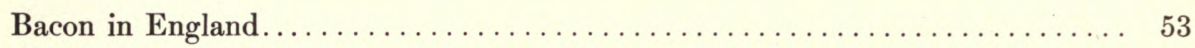

Selling prices of Danish and Canadian Bacon in England............ 55

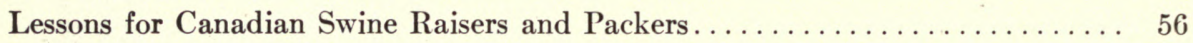

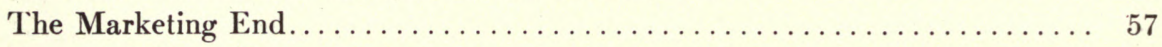

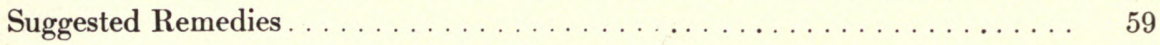





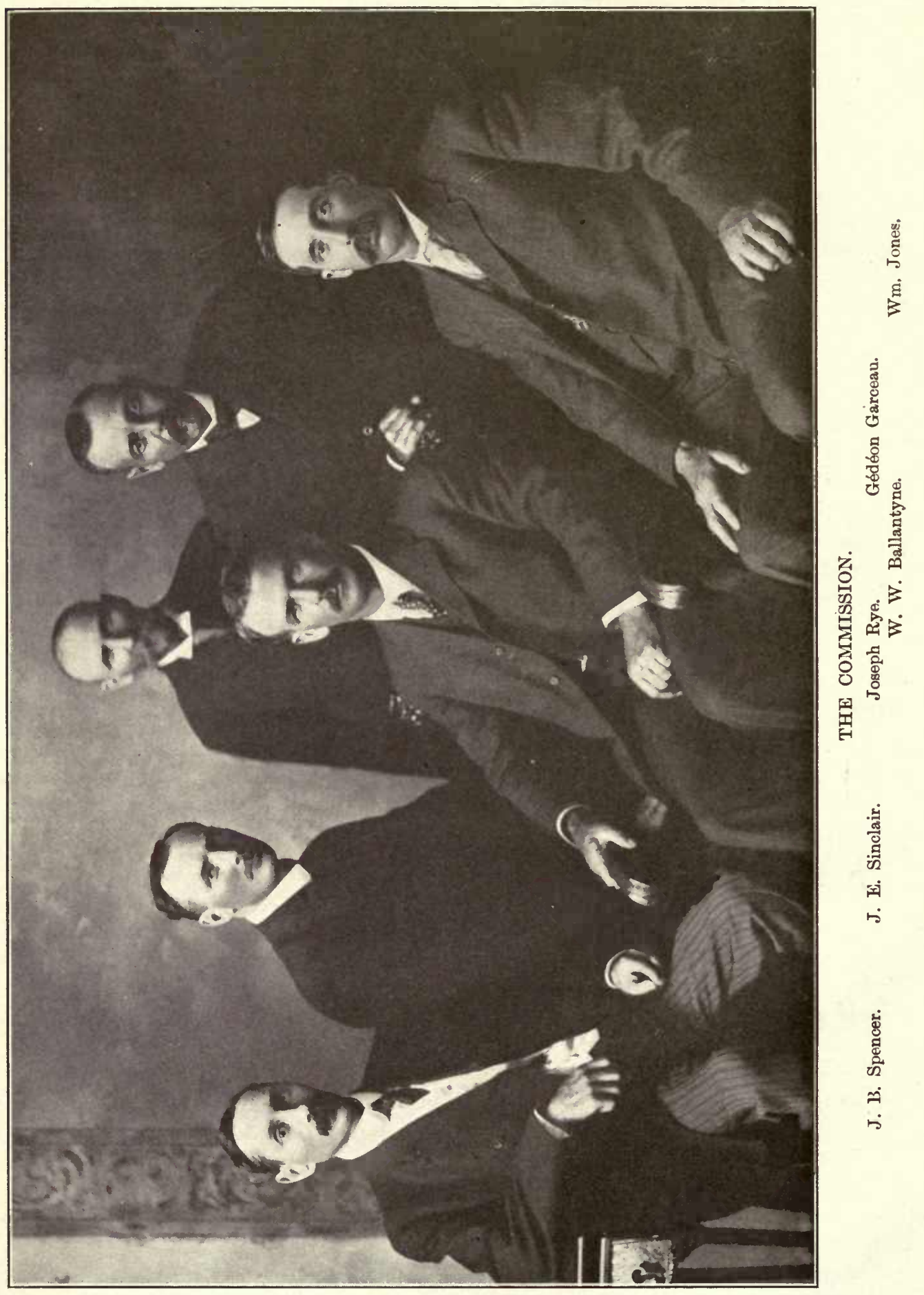




\section{INTRODUCTION}

During the ten years ending with 1905, marked progress was made in Canada in the swine rearing industry. The annual production greatly increased and the majority of pigs raised changed from the ordinary pork type to that suitable for the production of bacon of the most valuable class. From small beginnings in the early nineties the export bacon tra de with Great Britain grew by rapid strides until in the year 1905 Canada supplied Great Britain with about 20 per cent of her imported bacon. For three years this high level was maintained, but since 1907 a rapid decline has been in operation until there was general fear expressed that the industry, in so far as the export trade is concerned, is seriously menaced. The situation has given rise to much debate as to the actual cause, and keen anxiety in regard to the future of the industry. During the session of Parliament of 1909 delegations representing different classes interested in the industry came to Ottawa to recommend to the Government remedies varying according to the view point of the respective delegations. Some wanted alterations made in the Customs duties, others urged demonstrations in the cheap production of pork, while others again suggested the wisdom of sending a delegation to Denmark and the United Kingdom to study the methods of pig raisers who continue to supply in large quantities the British market with high class bacon. The Honourable the Minister of Agriculture, recommended to Parliament the wisdom of getting for the Canadian farmer information that may be gathered from the methods of those whose industry has outstripped that of Canada under universal conditions of high priced feed. Parliament approved the idea and voted ten thousand dollars to carry out the project. To appoint a suitable commission was the next step and this the Minister did, guided largely by the recommendations of swine raisers in provinces where hog raising is carried on as an important branch of agriculture.

From the Province of Ontario were chosen W. W. Ballantyne, of Stratford, and Wm. Jones, of Zenda. Mr. Ballantyne, a prominent breeder of dairy cattle and official in connection with the Ontario Winter Fair, and other important public enterprises, is an extensive feeder upon his own farm of swine for the market, and has a deep interest in the several Ballantyne cheese factories, at each of which hundreds of hogs are fattened each year upon whey and purchased grain foods. Mr. Jones, who is a past president of the Dominion Swine Breeders' Association and a director of the Ontario Winter Fair, is a large dairy farmer, and the owner of a herd of Yorkshire swine. He is a recognized expert judge of swine and each year officiates at one or more of the largest fairs in Canada. From the Province of Quebec was appointed Mr. Gédéon Garceau, of 'Three Rivers. Mr. Garceau, a prominent stock breeder and dairy farmer, occupies a foremost position in the live stock association life of the province. He is familiar with the English and French languages, and does much work in judging at exhibitions and lecturing at Farmers' Institute meetings. Mr. Joseph Rye, of Edmonton, Alta., an extensive stock raiser, was named from the West. He is among the most prominent and successful breeders and exhibitors of pure bred swine iu his province. Mr. J. E. Sinclair, the representative of the maritime provinces, a dairy 
farmer and swive raiser, is a man of affairs in the agricultural life of Prince Edward Island. The sixth reprentantive, the secretary and editor, occupies in the Live Stock Branch office next in rank to the Live Stock Commissioner.

The members of the Commission individually and collectively undertook the task laid upon them with keen earnestness. The Commission sailed from Montreal on June 18th, arriving in London on the 27th. The three following days were spent gathering information in respect to Canadian and Danish bacon, and the trade in these products. They arrived in Denmark on July 2nd, and until the 16th followed the itinerary mapped out by the Department of Agricultu re in charge of Mr. P. A. Morkeberg, Live Stock Commissioner for Swine and Red Danish Cattle, who acted as guide and interpreter. Returning by way of Germany and Holland a day was spent with advantage in a Dutch bacon curing and hog raising centre. Upon returning to Great Britain, Scotland received attention first, then Ireland and last England. In addition to studying swine rearing as a commercial work, the Commission visited prominent herds of pure bred stock and such leading agricultural exhibitions as the "Highland" of Scotland and the "Royal Lancashire" of England. The Commission was well received everywhere. The report indicates the success attained in securing information.

Details regarding the kinds of establishments, the locations of farms, packing houses, the names of officials, and other prominent men who aided the Commission, are given in the letter to the Minister published on a preceding page, or are to be found in the body of the report.

THE EDITOR. 


\section{GREAT BRITAIN.}

There is much to be learned from a study of the methods of British swine raisers. In many districts hogs are reared in large numbers on almost every farm, and in swine feeding as in other branches of the live stock industry, profitable methods of feeding are followed, nor are farmers afraid to buy feed for pigs or other stock. It would be difficult to find a stock farmer who does not have feed bills to meet. High rents have to be paid for the land, which make it necessary to insure good crops, and without manure, and plenty of it, full returns from the soil are not obtainable. It is true that fertilizers, as such, are purchased for many farms, but a great many farmers depend more upon yard manure than upon 'artificials', but the yard manure must be good and it cannot be so unless the stock making it are well fed. It therefore follows that the farmer in buying food for his stock feels, that besides getting a direct return in meat or milk, he is feeding his land in order that it may yield a full return for the labour and other expenses put upon it. It must not be inferred, however, that to secure fertilizers is the only or the chief object of the farmer of Great Britain in feeding hogs. He does this for direct profit and is seldom disappointed in getting a fair return in spite of the comparatively high prices that have to be paid for food stuffs.

Statistics covering twenty-nine years show that the number of pigs reared in Great Britain does not vary much from year to year. Since 1879 the number has never gone below the two million mark, nor has it reached three millions in any one year. The figures for $1908,2,823,482$, are practically the same as for 1904, 1897, 1896 and 1891, while in some of the intermediate years it has gone a little below 2,200 000. The number for 1908 shows an increase of 186,716 over the previous year. The rise was confined to England and Wales, there being a decrease of 2,850 (about two per cent) in Scotland.

In the total number Scotland plays only a small part, there being kept in that country only one pig for each thirty-four acres of land under crop and grass, while in England and Wales one pig is kept for each ten acres of arable land. Compared with other farm stock Scotland had in $1908,143,784$ pigs to $1,174,405$ cattle; 204,507 horses and 7,439,495 sheep. In that year the stock population of England was 2,439,087 hogs; 5,980,125 cattle; 1,179,902 horses and 15,957,875 sheep; the ratio for Wales being practically the same as for England. It will therefore be seen that the English farmer, as a rule, gives much more attention to the breeding and rearing of swine than the farmer of Scotland.

\section{England.}

Swine raising is an important branch of English agriculture. On almost every farm at least a few hogs are kept, while on many, pork production is the chief branch of live stock husbandry followed. The English farmer is an intelligent husbandman. He pays heavy rents and much money for hired help and must get the maximum of returns from the land he cultivates. On every farm there is more or less by product suitable for hog feeding and this cannot be allowed to waste. English people prefer home fed meats, whether it be that of the ox or the pig. Wiltshire bacon originated in England, and those other countries that are now producing it are simply following England in methods of production. Other cuts and kinds of pork and bacon have a place in the English market, in fact almost every large city, of which there are many, calls for a special kind of pork or bacon. For instance, Birmingham takes a heavy pork while London is better satisfied with the lighter classes. In some cities the demand is for quite heavy pork hard cured, while in others mild cured is favoured. To supply these several varieties of pork meats the methods of pig raisers differ materially in different districts. To thoroughly investigate swine raising in England 
would occupy more time and study than the Commission had at its disposal for that country.

The diversity of systems of pig raisers in England is demonstrated by the prononnced differences to be found in the breeds of pigs kept. The large Yorkshire is quite a different pig from the Middle White, while the Berkshire, the Tamworth and the Large Black each possesses its peculiar characteristics, as determined by the minds of the breeders of these several types. Yet they all originated in little England where they are kept separate and distinct, each occupying a field of its own, and each possessing qualifications highly prized by its champions.

Dividing England into two parts the prevailing colour of the pigs kept north of the Thames is white, while south of that dividing stream it is chiefly black. True one finds both white pigs and black ones and those that are spotted in most parts of England, and red ones also distributed here and there. At present the tendency is towards greater uniformity over the country in cross bred pigs on accnunt of the growing popularity of the Yorkshire, which so strongly stamps its colour on its offspring.

Having in view the bacon industry the Commission while in England confined its investigation chiefly to districts noted for the raising of bacon pigs. Opportunity was taken to visit a few prominent pure bred herds. Some time was spent also in the offices and storehouses of large commission firms examining the several classes of imported bacon and learning all that was possible in regard to the needs and conditions of Canadian bacon and the chief points of difference between this and its competitors.

The itinerary of the Commission in England was decided upon chiefly from informaation secured at the instance of the Canadian High Commissioner, from Sir Thos. Elliott, Secretary of the Board of Agriculture. Sir Thomas not only informed the Commission of favourable districts but by letters of introduction opened the way to comfortable receptions.

PURE BRED HERDS.

Wherever it was convenient to do so, owners of pure bred herds were called upon. Apart from many casual visits made in this way such noted herds were visited as Holywell Manor, so long associated with the name of that champion of the Yorkshire, Mr. Sanders Spencer; the Hasketon herd of Large Blacks owned by Mr. C. F. Marriner near Ipswich. in Suffolk, and the Berkshire herd of J. W. Kimber, near Abingdon, Berks.

Holywell herd is interesting to every visitor. Its ownership and management has been transferred by Mr. Sanders Spencer to his son Charles, who maintains a fine stock of the old excellent type built up during many years of hard work by his father. Here about a score of brood sows and several boars representing famous old families, built up at Holywell, were seen in addition to a choice lot of young stock, including pens of show animals that at each show visited added to the glorious victories of this famous herd. The members of the Commission were impressed with the rational treatment afforded the breeding stock, most of which, unless suckling litters, had the range of a grass pasture adjacent to the barns. It was not surprising to find the stock thus treated by a pupil of so thorough an authority on swine breeding and rearing as the founder of the Holywell herd. No systematic attempt is made at Holywell to discover a cheap ration for the pigs, the constant object of the proprietor being to secure a maximum of healthy growth consistent with future vigor and usefulness. This is secured by the use of such healthful foods as shorts, oat incal, barley meal, milk, roots and other green foods. These foods judiciously blended and given in quantity and proportion according to the age and purpose of the swine, produce pigs big for their age and full of stamina and activity.

Mr. Spencer is, however, a master feeder when direct profit is concerned. He recommends that only as much food be given at a time as is eaten with a relish. Flour mill refuse is the basis of the grain mixture that he recommends. For a month or two after weaning shorts constitutes the chief part of the ration, but he also gives a little whole wheat or pease once a day. After this period mixed meal composed of barley, corn and wheat may be added to the shorts and bran. This is continued until the pigs are about five months old, when they are able to digest food comprising meal to the extent of three-quarters of the ration. 


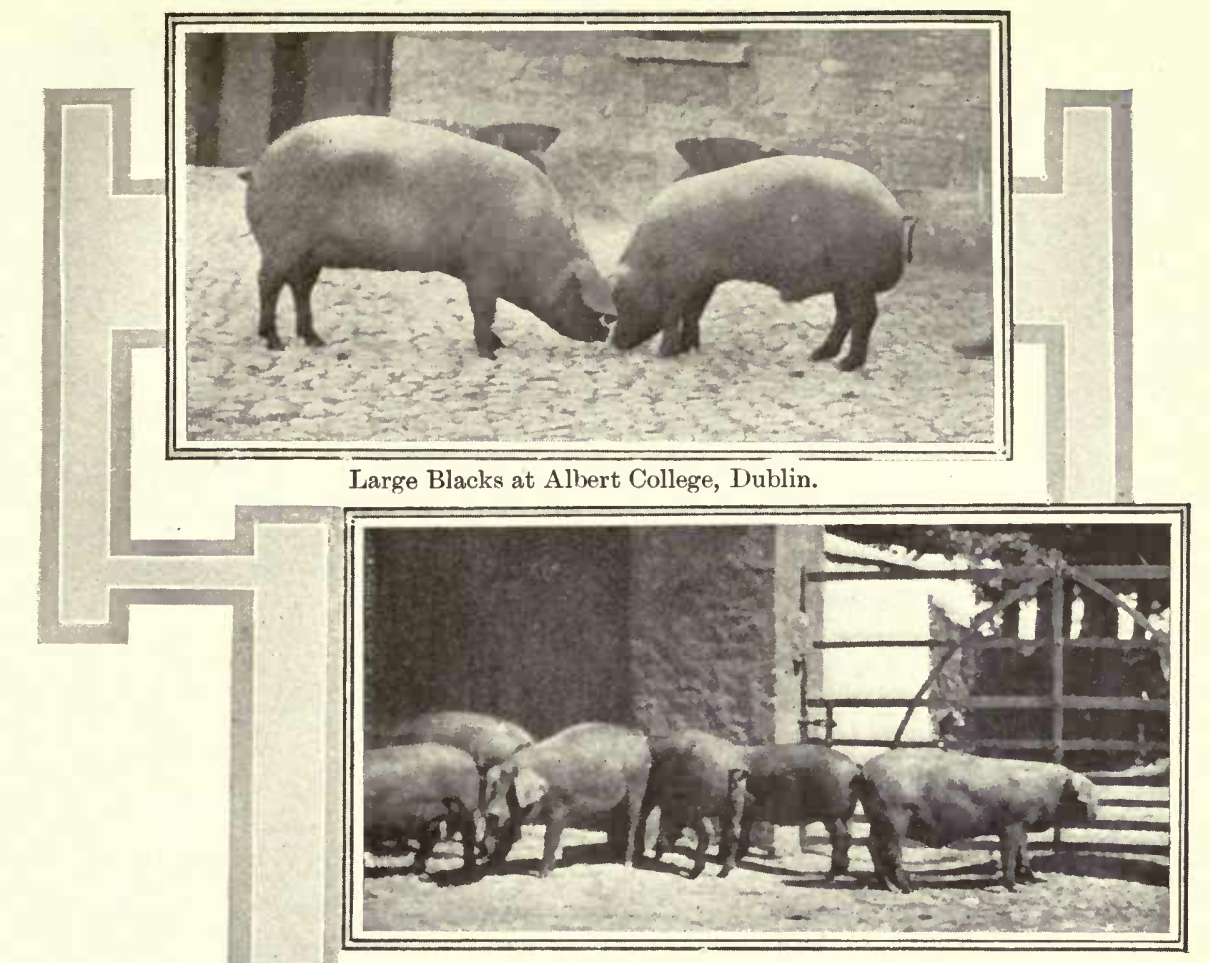

Large Black"Shoats, on an Irish Farm.

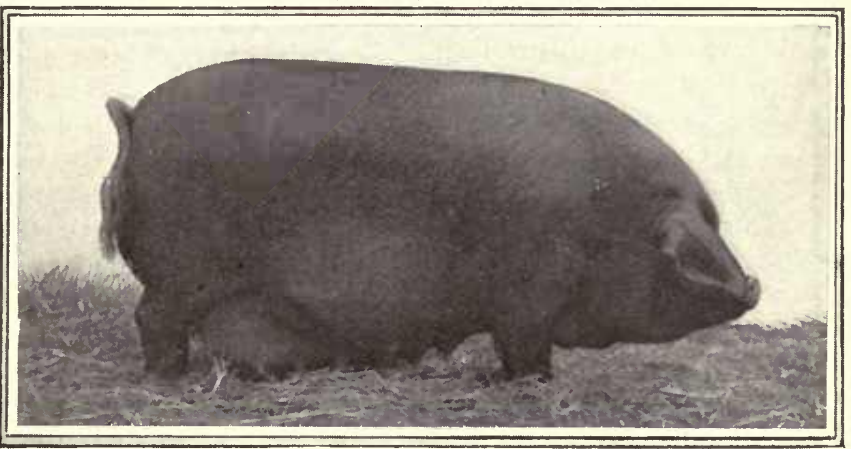

A Typical Large Black Sow.


A Typical Large Black Boar. 

This is mixed with water twelve hours before being fed, and in cool weather hot water is used, to bring the food up to the temperature of new milk. Whenever skim milk is available it is substituted for water in an amount equal to its own bulk.

Both in Ireland and England much was heard in favour of the Large Blacks. Wherever these swine or these grades were seen by the Commission they made a favourable impression. Advantage was therefore taken at the first opportunity to visit a prominent herd of this breed. 'The herd visited was that of Mr. C. F. Marriner, in the county of Suffolk, that has in recent vears won a large number of championship awards at leading shows. Here was found a large herd of brood sows and a few stock boars that individually and collectively rank high among the herds of swine of England for the profitable production of pigs for bacon requirements. In earlier years the Large Black was a bit rough in the shoulder, short in the hind quarter and light in the ham. For years Mr. Marriner has given special attention to these points until his present herd, which is uniform in type and lusty in vigour, show none of these old defects. Many of the breeding animals were on grass pasture which of itself seemed to be sufficient to maintain the stock in good breeding form. The heartiness of these pigs was spoken of everywhere and the members of the Commission are satisfied that the claim is well founded. Mr. Marriner claims that the narrow range of vision of the Large Blacks, due to the drooping ears, is conducive to docility and thrift.

The Berkshire in England as in Canada is being stretched out. In the herd of Mr. Kimber, in which many prize winners have been produced, were many lengthy, smooth shouldered, deep sided sows. There was an entire absence of the chubby, fat-backed, shortfaced pigs that were common in England some years ago. It is observed that the bacon type Berkshire is a much better breeder and suckler, and, therefore, a more profitable hog than the old fashioned kind. The appreciation of the British breeder of the new type was apparent at an auction sale of Berkshires, attended by the Commission, where only the more rangey. strong boned pigs brought good prices. A number of neat, fine boned animals brought no more than pork values.

FEEDING BERKSHIRES FOR BACON.

Mr. Kimber, who is a tenant farmer, explained his system of feeding fattening pigs. The litters, which are weaned at eight weeks, get green food, such as pulped mangels and swedes, and whole dry grain, such as corn and beans. On this they are kept growing nicely. At four months the grain is given ground and fed in such quantities as to have the pigs at six months old weighing from 150 to 170 pounds. In winter the chop is mixed with pulped roots twelve hours before feeding. In the early stages one part of meal is given with three parts of roots, then as the pigs commence to leave roots in the trough, the meal is gradually increased until when within two weeks of finishing the roots are entirely withheld so as to get the pigs off as quickly as possible. The pigs are usually marketed when they reach 180 pounds dressed.

To induce a good flow of milk in a sow Mr. Kimber depends chiefly on shorts and oat chop, with an occasional feed of roots or other green feed as a change. He does not consider barley meal good for milk, but likes it for fattening swine.

In the county of Berkshire pork production does not hold a prominent place in Agricultural practice. Those who feed at all extensively prefer cross-bred stock, the produce of Tamworth dams and Berkshire sires. This cross, it is claimed, gives a thrifty, heavy weighing pig of a class to suit either the bacon or the pork and ham trade. In the district visited very little milk is fed to pigs because of the demand for it for the London market. Wishing to procure the best possible information on the rearing of pigs for the production of bacon, the county from which the "Wiltshire" side takes its name was visited. At the town of Calne, in Wiltshire, is located the curing house of the old established firm of bacon curers, that of the C. \& T. Harris Co. No name in the English bacon trade is better known than that of Harris \& Co., and no make of bacon is more firmly established. Harris Wiltshire bacon commands a fancy price in all parts of Great Britain, and for many years regular large shipments have been coming to Canada, in response to a demand from families that believe there is no other to compare with English bacon. 


\section{Harmony between Packer and Feeder.}

Most of the farms in the neighbourhood of Calne feed pigs in large numbers and practically all go through the Harris factory. Here, strange to say, very few pigs are bred, the feeders preferring to buy stores at three to five months old. An interesting and profitable tour was made among feeders in the neighbourhood. It was interesting to find a marked uniformity in the ideas and methods of feeders as well as a very general feeling of sympathy between the feeders and the packing company. This comfortable and very profitable state of affairs is the result of harmonious co-operation instituted largely by the packers who conscious of their entire dependance on the supplies and condition of hogs have done much to encourage production of the right sort. Messrs. Harris \& Co. have interested themselves in cheapening production but in all they have done have never lust sight of quality. Some years ago they made careful tests of breeds and crosses of pigs and after determining the superiority of the Yorkshire cross undertook to supply boars of this breed at the lowest possible cost and on easy terms of payment. The next step was to encourage production in quantity and quality of pigs. To accomplish this the Wilts County Council was induced to take up a series of pig feeding experiments and demonstrations in cheap production. A Committee of ten members consisting chiefly of farmers was formed. Contributions to carry on the work were made by Lord Lansdowne whose estate joins Calne, the Harris Company and the County Council. A thoroughly capable and painstaking secretary was appointed to keep records, while a son of one of the leading farmers was entrusted with the actual feeding. The tests and demonstrations were carried on for five years after which time the Secretary and scientific adviser gave courses of lectures throughwut the country and distributed reports.

\section{Feeding Experiments.}

During the five years 720 pigs were fed from store to finished condition. No special care was taken to select stores, which were of no special breed, and were bought in the manner customery among the great majority of the farmers in the district. For the feeding tests comfortable and sanitary pens were erected each to accomodate ten pigs. The foods used were those commonly employed in that part of England and consisted of the following: corn, barley, oats, peas, and bean chop, bran, separated milk, potatoes and mangels as also a number of proprietory foods. The dry food was soaked in water in the proportion of one peck of the former to 5 gallons of the latter, except when separated milk was used it replaced its own volume of water in the mixture. The potatoes were boiled and the mangels sliced. The pigs were fed three times a day ås much each time as they could clean up.

The weights of pigs at the commencement of fattening ranged from about 90 to 140 lbs. The live weights when finished ranged from 133 to $236 \mathrm{lbs}$. The feeding periods ranged from 7 to 14 weeks. Ari examination of the exhaustive report of the tests shows the following conclusions :-

\section{Gains from Different Diets}

The diets which gave the highest weekly increase in live weight were:-

\begin{tabular}{|c|c|}
\hline & \\
\hline 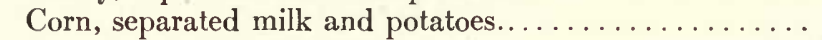 & 10.1 \\
\hline $\mathrm{Ba}$ & 13. \\
\hline Cor & \\
\hline d potatoes. & \\
\hline
\end{tabular}

\section{Diet and Quality of Pigs.}

A larger proportion of best pigs for bacon was obtained with barley than with corn feeding.

The addition of either milk or bran, but especially the latter, to barley or corn raised the proportion of best pigs. 
The addition of potatoes to barley increased the proportion of best pigs, whilst a similar addition to corn decreased it.

The addition of beans and oats to corn increased the proportion of best pigs.

\section{Most Profitable Diets.}

To produce 100 lbs. increase in live weight about 5 per cent more corn than barley was required.

When fed with barley 63.4 gallons of separated milk replaced $127 \mathrm{lbs}$. of barley, or one gallon of separated milk equals 2 lbs. of barley.

When fed with corn 59.6 gallons of separated milk replaced 186.7 lbs. of corn, or 1 gallon of separated milk equals 3 lbs. of corn.

N.B.-Fresh separated milk gave a better result than stale separated milk.

When bran was fed with barley, $143.9 \mathrm{lbs}$. of bran replaced $179.7 \mathrm{lbs}$. of barley, or 1 lb. of bran equals $1 \frac{1}{4} \mathrm{lbs}$. of barley.

When bran was fed with corn 155.8 lbs. of bran replaced 181.3 lbs. of corn, or 5 lbs. of bran equals 6 lbs. of corn.

When pea meal was fed with corn $103 \mathrm{lbs}$. of the former replaced $183.5 \mathrm{lbs}$. of the latter, or $1 \mathrm{lb}$. of peas equals rather more than $1 \frac{3}{4}$ lbs. of corn.

When bean meal was fed with corn $101 \mathrm{lbs}$. of the former replaced $189 \mathrm{lbs}$. of the latter, or $1 \mathrm{lb}$. of beans equals $2 \mathrm{lbs}$. of corn nearly.

\section{Increase in Dressed Weight.}

To produce $100 \mathrm{lbs}$. dressed weight, the quantity of barley alone used was very slightly in excess of the corn meal alone.

81.6 gallons of separated milk fed with barley, effected a saving of $141.4 \mathrm{lbs}$. of the latter, or 1 gallon of separated milk equals $1 \frac{3}{4}$ lbs. of barley meal.

72 gallons of separated milk fed with corn meal replaced $205.2 \mathrm{lbs}$. of the latter, or one gallon of separated milk equals rather more than $2 \frac{3}{4}$ lbs. of corn.

Where bran was fed with barley, 202.5 lbs. of bran replaced 172 lbs. of barley. In this case therefore the value of the bran in increasing dressed weight was very considerably less than that of the barley.

Where bran was fed with corn, $186 \mathrm{lbs}$. of the latter were replaced by $191 \mathrm{lbs}$. of the former, i.e., the two food stuffs were of nearly equal value in the production of dressed weight.

Where pea meal was fed with corn, $131.5 \mathrm{lbs}$. of the former replaced $173.5 \mathrm{lbs}$. of the latter, or $1 \mathrm{lb}$. of peas equais $1 \frac{1}{3} \mathrm{lbs}$. of corn.

\section{Quatity of Meat.}

The five diets which gave the best quality meat, arranged in order, are as follows:-

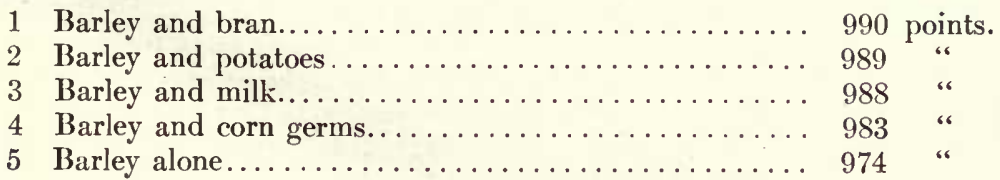

The practical nature of the lessons learned from these tests are indicated in the above deductions. 'The series of lectures held in which the whole work was made plain established an exceedingly rational system of pig feeding throughout the district. Through this work also sympathy between feeders and packers was increased and this has never been lost. Whenever a disputed point of any moment arises the question is submitted to a committee agreed upon by the County Council and the packers to be dealt with. Some time ago a number of patrons of the factory complained that they were being too heavily charged for shrinkage that takes place while the carcasses are cooling. To settle this ex- 
tensive test were carried out under the scrutiny of a satisfactory committee upon whose report a scale of shrinkage according to weights of pigs killed was fixed. Since then farmers supplying hogs are satisfied to allow $4 \mathrm{lbs}$. off the weights of newly slaughtered hogs weighing $180 \mathrm{lbs}$. alive and $5 \mathrm{lbs}$. off pigs weighing over this amount. By following this system of settling disputes strained relationships between packers and pig raisers have never been allowed to arise to the great advantage and comfort of all concerned.

\section{The System of Buying.}

From time to time when the packers find it necessary to change their prices they send out postal cards announcing the new values for the different classes of pigs. Farmers who have pigs ready can book shipments seven days ahead at the current market price. The packer reserves the right to order the booked pigs delivered at the end of the booked period. Unless the packers do this and values do not drop the farmers can rebook for another seven day period. As already pointed out pigs are all bought at dressed weight. The weights are taken as soon as the carcasses are dressed when a deduction for shrinkage while cooling is made according to a standard scale for different sized hogs.

This firm carries an advertisement in leading live stock papers offering free transportation 100 miles on lots of 10 pigs, and proportion of transportation on smaller lots. As on their post cards they quote graded prices for pigs of different weights. The weights commanding the highest price are from 120 to $170 \mathrm{lbs}$., dressed weight, and the lowest, except sows and the like, for pigs 200 to $220 \mathrm{lbs}$., dressed weight.

\section{Farms Visited.}

The Commission was fortunate in being able to visit the farms of a number of feeders for the Harris Wiltshire factory. Among these were "The Sands" farmed by Mr. F. Smith, and "Lower Sands" farm leased by the former's son, Mr. A. J. Smith, who fed the experimental pigs during the five years tests and demonstrations. On Mr. A. J. Smith's farm were pens containing pigs in all stages of fattening. One lot of 22 head about two months old had just been purchased at $\$ 4.85$ each. Here, as in almost every district visited, cross bred pigs are preferred to pure breds. Berkshire, Yorkshire and Large Black characteristics were evident in the pens. The pigs were getting slop made from barley meal and bran. All were kept a little short of feed and all except those near the finished stage had roomy yards to run in. Skim milk was purchased at one penny a gallon or 20 cents per 100 lbs. At three months old each pig is allowed two quarts of milk per day; when it has reached $100 \mathrm{lbs}$. one gallon per day is fed but never more. All were getting a small quantity of green food such as vetches, clover, cabbage, etc. Pigs fed in this way usually go to market at 8 months old weighing about $160 \mathrm{lbs}$. dressed. As the finishing approaches a small quantity of corn is fed but a little bran or shorts is continued to the last. The pigs are fed four times daily -8 and 11-30 a.m. and 3.30 and 8 p.m. Unless he could get milk at reasonable cost Mr. Smith would not feed pigs extensively.

Another farm visited was that of W. A. Smith, a tenant of Lord Lansdowne. On 340 acres Mr. Smith keeps a herd of about 110 dairy Shorthorn cows, sells milk and buys back separated milk at one penny a gallon. He buys practically all the feed he uses, his food bills usually reaching $\$ 10,000$ per year for cattle and swine. He is a great believer in keeping the land up, and in buying feed realizes he is fertilizing the fields. Mr. Smith buys all his pigs at about 4 to 5 months old and usually has them ready for market after two months feeding. He usually has 200 pigs feeding and these cost about $\$ 1$ each to feed per week. In August the feed given consisted of barley meal, bran and low grade flour made into a slop with milk and water. The grain mixture consisted of two parts barley meal, one part bran and one part flour. This was the standard for all stages except that the slop was made a little thicker near the end of the fattening period. In winter mangels are fed whole once a day, and pease and beans are given instead of so much bran. In summer a good deal of rough grass, clover and other green fodder is given to keen the pigs thrifty. 


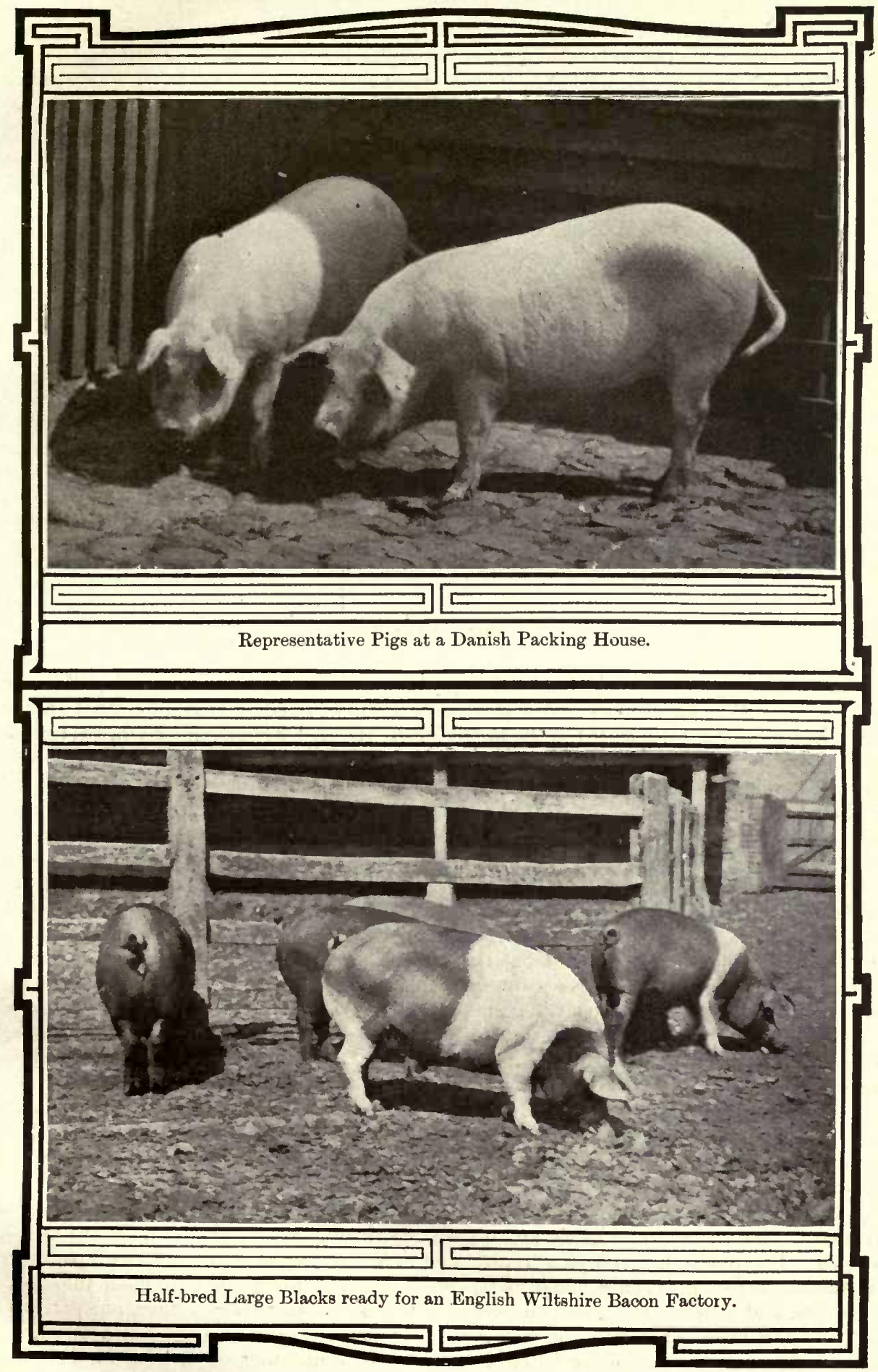



Other feeders in the neighbourhood feed much after the same system as the two Messrs. Smith. One other feeder, it might be mentioned, makes cheese at home from the milk of sixty cows. The whey is fed with barley meal to pigs. It is mixed one meal ahead. Both pigs and grain are purchased. The pigs at 4 months old cost $\$ 10$ each, while barley meal cost $\$ 1.35$ per 100 pounds. At this time the price of pigs was practically 13 cents per pound dressed weight, equal to about $\$ 9.50$ per 100 pounds live weight. This feeder claimed his pigs made a good profit.

On one farm visited pigs are bred and fattened. The litters are weaned at 8 weeks, then allowed to run out for 4 to 6 weeks before being put up to fatten. They are made to dress 180 pounds at from 6 to 7 months old. They are fed three times a day on one part bran and five parts barley meal made into a slop with milk and water mixed one meal ahead. Another feeder finds virtue in the use of raw linseed oil. Half a gallon given to 64 pigs per day in their feed was claimed to keep the digestive system in fine condition, insuring rapid gains.

\section{Breeding and Rearing.}

A large proportion of the pigs fed in the county of Wiltshire are bred in the east of England, chiefly in the county of Suffolk. Many finished pigs cured by the Harris firm are shipped from this county. To learn how pigs are bred and reared the Commission visited Suffolk where they were taken charge of by Mr. Maurice Wright, who manages the pig department of the Eastern Counties Co-operative Farmers' Association. Mr. Wright handles about 1,000 hogs per week for the members of this association. He keeps in touch with all the available markets and sells to the best possible advantage. By the adoption of this system of selling, a very effective combination of middlemen buyers has been entirely broken up.

In the part of Suffolk visited a very large number of pigs are reared. It is estimated that fully eight brood sows are kept for every 100 acres of land farmed. About 50 per cent of the produce of these are shipped out as stores to be fattened elsewhere, many going to the Wiltshire district. A very general reason given the Commission for raising so many pigs was that it afforded an excellent means of keeping up the fertility of the soil. 'Through the co-operation of the members of the association heavy supplies are avoided in seasons of probable low prices. Many of the sows kept are of the Large Black breed, and these are usually crossed with the Yorkshire. Pigs bred in this manner are extremely popular with the farmers visited. Comparatively little milk is available for pig feeding in this county, hence the selling of so many logs in store condition. Not only are feeders anxious to have milk for finishing, but packers of Wiltshire sides are extremely partial to milk fed hogs. Shorts, bran and roots comprise a large proportion of the foods used for breeding and young pigs in Suffolk. To these foods barley is added for fattening hogs. Where raisers have available pasture land sows are given their liberty in summer, but high rents makes this unprofitable on many farms.

\section{Scotland.}

The districts in Scotland visited by the Commission consisted chiefly of the counties lying between Glasgow and the southern coast. In this part of Scotland dairy farming is the rule. Nearly every farm has a good milking herd from which either cheese or butter are produced. Outside of these counties comparatively few hogs are reared except near cities and towns which furnish large quantities of kitchen offal. In the cheese sectionsthe home of the Scottish Chedder-the majority of farmers makes up their own milk at home. Each, therefore, makes upon his farm a large quantity of whey, and to consume this he maintains a good stock of feeding swine. As a rule these are not bred upon the farms, but bought in at 3 to 4 months old. Unless one breeds his own pigs his pens are likely to be empty during the winter months, as the Scots farmer, like many others, does not believe pigs can be fed profitably without dairy offal, more especially during the cold season of 
the year. It should be pointed out, however, that the average Scots pig pen is not constructed to provide that comfort on which profitable feeding so much depends in cold weather.

In creamery and cheese factory sections the fattening is cliefly done at the plants. Whereas most of the farm fed logs are bought as 'stores,' the factory people prefer to rear their own stock, and to this end keep on hand a large number of brood sows. One of the chief reason given for this course is to avoid getting disease into the stock. In addition they are better assured of well bred and thrifty stock to feed than if their pigs were purchased in the open market.

The factory sections visited were in the counties of Wigton and Kirkcudbright in the south west of Scotland. At each of these plants from 500 to 600 pigs are fed eacli year. Here, as at almost all districts visited, cross-bred pigs are preferred. At Dunragit 75 sows are kept-chiefly pure bred Yorkshire and to these 'Tamworth, Berkshire and Middle White boars are principally bred. The sows are carefully selected and cared for in such a way as to insure good litters. The sows when dry are carried cheaply on a ration of shorts, Paisley meal (a by-product of starch works much like gluten feed) and roots. The grain feed is given as a thin slop with skim milk or milk and water and sometimes with whey when cheese is Leing made instead of butter. Next page shows a group of dry sows kept in a grass plot at one of the creameries. 'Two litters a year are reared. 'These are born chiefly in July and January. The yield per sow is usually about 9 pigs weaned. The July litters were coming at the time of the Commissioner's visit, and a promising lot of pigs they were. These are carried over winter as stores to go out early the following season, while the January farrowings go away towards fall. The sows when milking are liberally fed on slops of mixed foods. A good deal of rice meal is used at times as also a preparation called 'Molassine,' consisting of a mixture of peat moss dried and ground fine and molasses. Molasses fed without the moss is too laxative, but when properly prepared with the cheap moss meal it constitutes an excellent and cheap food for pigs of all ages.

The litters are weaned at about six weeks old by which time they have learned to feed well. They are kept housed for two or three weeks after weaning and are fed on warm, cooked food consisting of shorts, barley dust and Pailsey meal. Feeding is done three times daily and no more is given each time than is eaten up clean. Very little skim milk or whey is given to young pigs unless in times of a generous supply. These foods are reserved for the fattening stock. When eight to ten weeks old the pigs are turned out.

During the summer their run is limited to a few acres but in winter fully 50 acres are given to a herd of 300 at one creamery. When winter arrives this ground carries considerable grass which the pigs graze all winter long. The swine feeder is much averse to keeping store pigs housed in winter as they often get lame when confined. They have access to dry comfortable cabins. Next page shows a group of pigs varying from 8 to 12 weeks old. These pigs in August were getting slop of mixed grain finely ground and one small feed each day of whole soaked corn. 'I hey were also getting sour milk and whey to drink. The aim of the feeder is to keep the pigs thriving well all the time. They are not housed until the last six weeks after which time they are rushed along on generous feed consisting chiefly of fairly thick slop made from skim milk, or whey with such meals as barley, corn and other heavy grain. At none of the factories visited are roots fed to fattening stock. These are highly prized for brood sows and store pigs along with shorts, molassine and Paisley meal. At three cheese factories and creameries visited, all owned and operated by one firm. about 2,000 fat pigs are turned off annually. At each place the pigs. have the by-product of about 3,000 lbs. of milk per day. All other food has to be purcliased. The pigs are marketed dressed weighing about $150 \mathrm{lbs}$. each. 'The transactions of the first few years have shown a small profit on the food purchased in addition to a return of about one cent per gallon for the skim milk and whey.

\section{Pork Making on Scottish Farms.}

Swine feeding at the dairy farms throughout the country is carried on chiefly for the purpose of turning to profit the whey produced from the cheese making operations. As a 


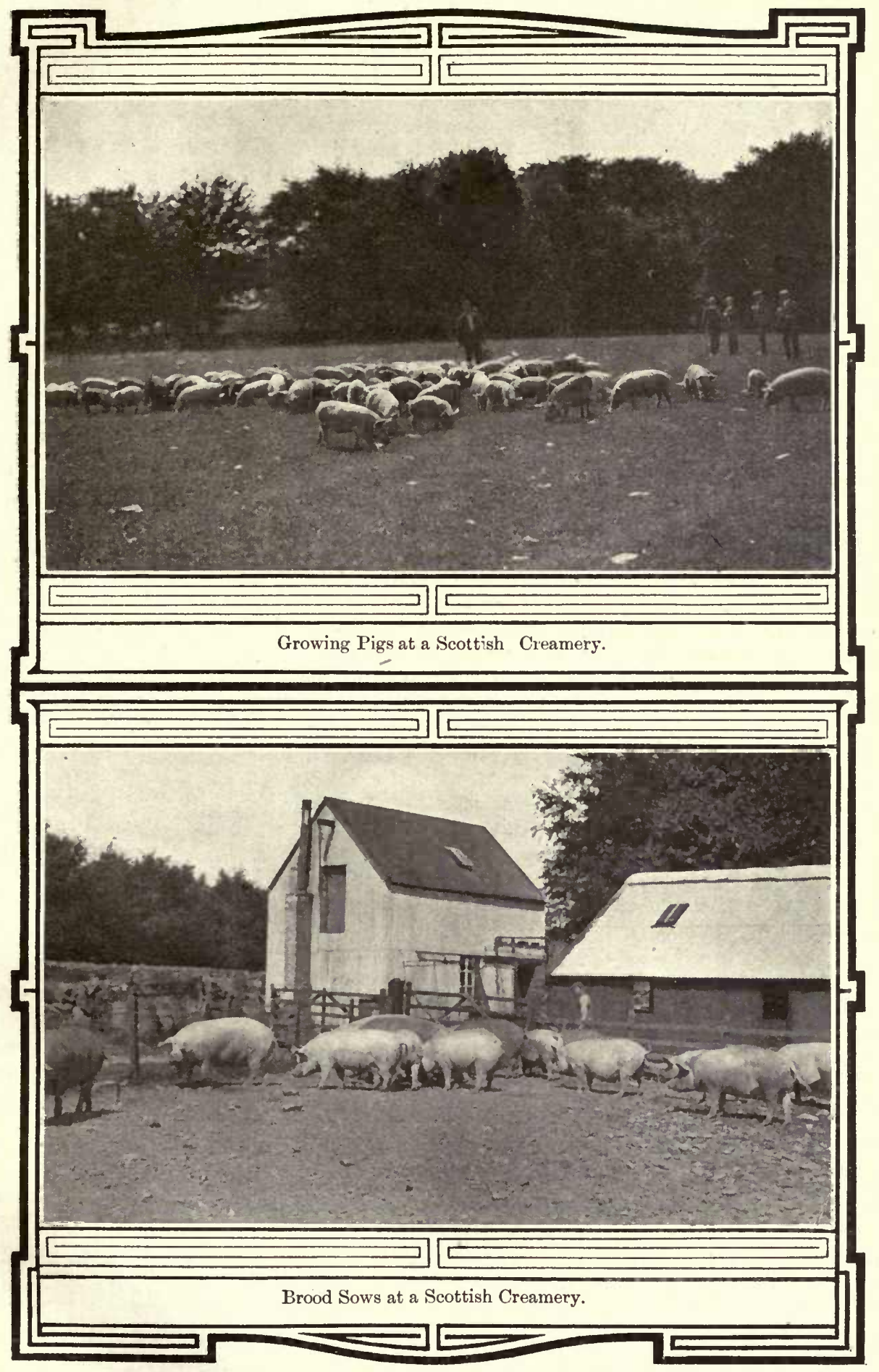



rule about two pigs are kept for each cow milked and in ordinary years from $\$ 5$ to $\$ 10$ per cow are made from the pork fed. While the pigs are young their food consists of whey and shorts given as a slop.

It is usually scalded and fed warm. As the pigs advance in age and weight the diet is strengthened by the addition of ground barley or corn to the ration and as the finishing approaches the slop is made thicker. In some cases pigs are bought when weaned while others secure theirs when three to four months old. In 1909 pigs 8 weeks old were costing about 30 shillings $(\$ 7.20)$ each while pork was selling dressed and skinned with head and feet on weighing about $150 \mathrm{lbs}$. at 13 shillings and 9 pence per stone of 24 lbs. equal to about $13 \frac{1}{2}$ cents per lb. The buyer slaughters the pigs on the farms.

\section{Feeding Experiments.}

The West of Scotland Agricultural College at Kilmarnock has for a number of years been experimenting with different kinds and mixtures of foods in pig feeding. When the Commission visited the College in July four lots of pigs were being fed. Each lot comprised 8 pigs each being given a different mixture.

Prof. Wm. Stevenson gave the Commission the following tables showing the results of the use of different foods and mixtures in experiments conducted in 1906, '07 and '08.-

EXPERIMENT OF 1906.

\begin{tabular}{|c|c|c|c|c|c|c|c|}
\hline Lot. & $\begin{array}{l}\text { No.of } \\
\text { pigs. }\end{array}$ & Food. & $\begin{array}{l}\text { Total live } \\
\text { weight at } \\
\text { beginning of } \\
\text { experiment. }\end{array}$ & $\begin{array}{c}\text { Period of } \\
\text { experiment. }\end{array}$ & $\begin{array}{l}\text { Total gain } \\
\text { in live } \\
\text { weight. }\end{array}$ & $\begin{array}{c}\text { Meals } \\
\text { consumed. }\end{array}$ & $\begin{array}{c}\text { Milk, } \\
\text { whey } \\
\text { consumed. }\end{array}$ \\
\hline & & & Lbs. & Days. & Lbs. & Lbs. & Gallons. \\
\hline 1 & 4 & $\begin{array}{l}\text { Separated milk and } \\
\text { barley meal....... }\end{array}$ & 342 & 42 & 217 & 434 & 504 \\
\hline 2 & 4 & Whey and barley meal & 450 & 42 & 217 & 434 & 672 \\
\hline$\overline{3}$ & 4 & Whey and corn meal. . & 453 & 42 & 239 & 448 & 672 \\
\hline 4 & 4 & Whey and Paisley meal & 460 & 42 & 283 & 448 & 672 \\
\hline 5 & 4 & Whey alone........ & 499 & 42 & 174 & $\ldots \ldots \ldots$ & 882 \\
\hline
\end{tabular}

EXPERIMEN'T OF 1907.

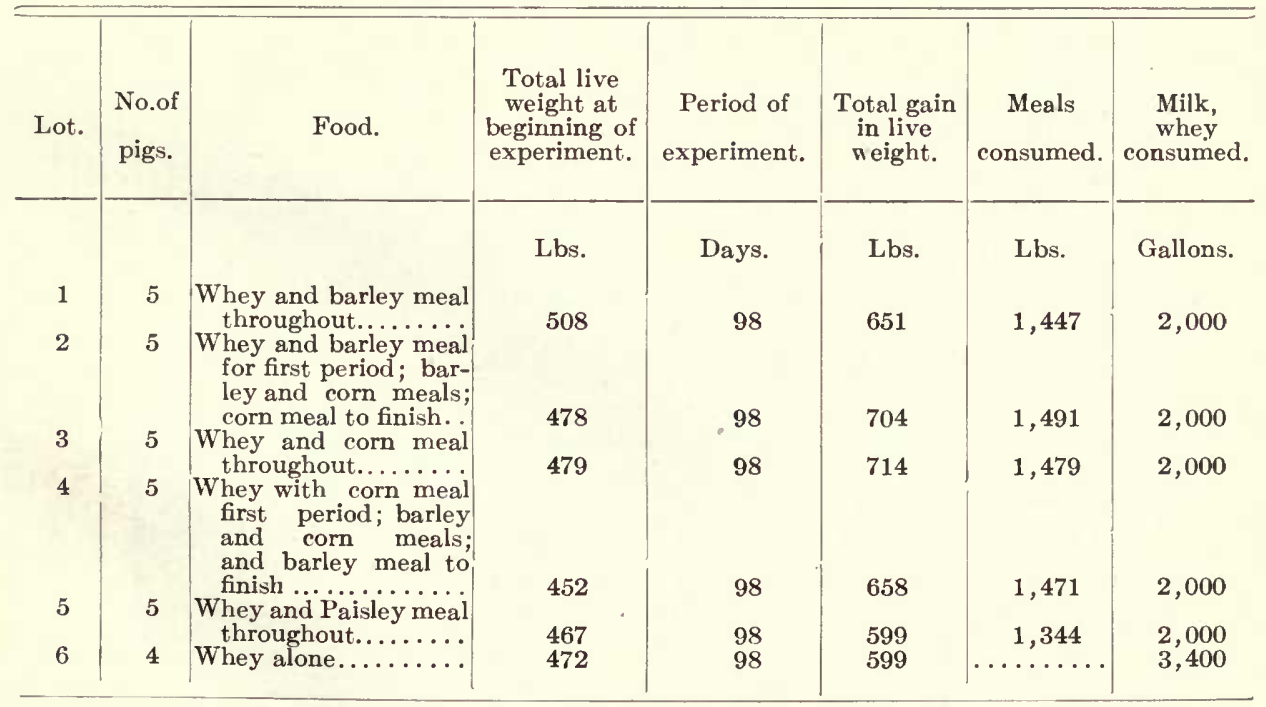


EXPERIMENT OF 1908.

\begin{tabular}{|c|c|c|c|c|c|c|c|}
\hline Lot. & $\begin{array}{l}\text { No.of } \\
\text { pigs. }\end{array}$ & Food. & $\begin{array}{l}\text { Total live } \\
\text { weight at } \\
\text { beginning of } \\
\text { experiment. }\end{array}$ & $\begin{array}{l}\text { Period of } \\
\text { experiment. }\end{array}$ & $\begin{array}{l}\text { Total gain } \\
\text { in live } \\
\text { weight. }\end{array}$ & $\begin{array}{c}\text { Meals } \\
\text { consumed. }\end{array}$ & $\begin{array}{l}\text { Milk, } \\
\text { whey } \\
\text { consumed. }\end{array}$ \\
\hline & & & Lbs. & Days. & Lbs. & Lbs. & Gallons. \\
\hline 1 & & $\begin{array}{c}\text { Whey and barley meal } \\
\text { throughout.......... }\end{array}$ & 462 & 77 & 518 & 848 & 1,100 \\
\hline 2 & 4 & $\begin{array}{l}\text { Whey with barley meal } \\
\text { first period; barley } \\
\text { and corn meals; } \\
\text { and corn meal to } \\
\text { finish............... }\end{array}$ & 545 & 77 & 543 & 1,078 & 1,100 \\
\hline 3 & 4 & $\begin{array}{c}\text { Whey and corn meal } \\
\text { throughout......... }\end{array}$ & 555 & & 555 & 1,079 & \\
\hline 4 & 4 & $\begin{array}{l}\text { Whey and corn meal } \\
\text { flrst period; barley } \\
\text { and corn meal and } \\
\text { barley meal to finish } \\
\text { Whey and Paisley meal }\end{array}$ & 481 & 77 & 436 & 892 & 1,100 \\
\hline \multirow[b]{2}{*}{6} & \multirow[b]{2}{*}{4} & \multirow{2}{*}{$\begin{array}{c}\text { barley meal to finish } \\
\text { Whey and Paisley meal } \\
\text { throughout.......... } \\
\text { Whey alone......... }\end{array}$} & 468 & 77 & 432 & 892 & 1,100 \\
\hline & & & 484 & 77 & 364 & & 1.850 \\
\hline
\end{tabular}

Pure Bred Herds.

Two noted herds of Yorkshire swine were visited in Scotland, those of the Earl of Rosebery at Dalmeny, and W. B. Wallace of Broomhouse. These herds, are located near Edinburgh, and a few miles apart.

'The stock, comprising these herds, may be described as the modern type of Yorkshire, such as have been awarded the best prizes at the Canadian National Exhibition during the past two or three years. The pigs are somewhat higher off the ground than the old type, and have longer heads. Smoothness of shoulder, length of side, and evenness and strength of back are predominating features. A number of Mr. Wallace's pigs were also seen at the Highland and Lancaster Royal Shows, where they won good prizes. In the pens of the Dalmeny herd were a number of exceedingly fine animals being fitted for the Smithfield Exhibition. The brood sows in each herd were an exceedingly good lot, full of vigor and very uniform. 


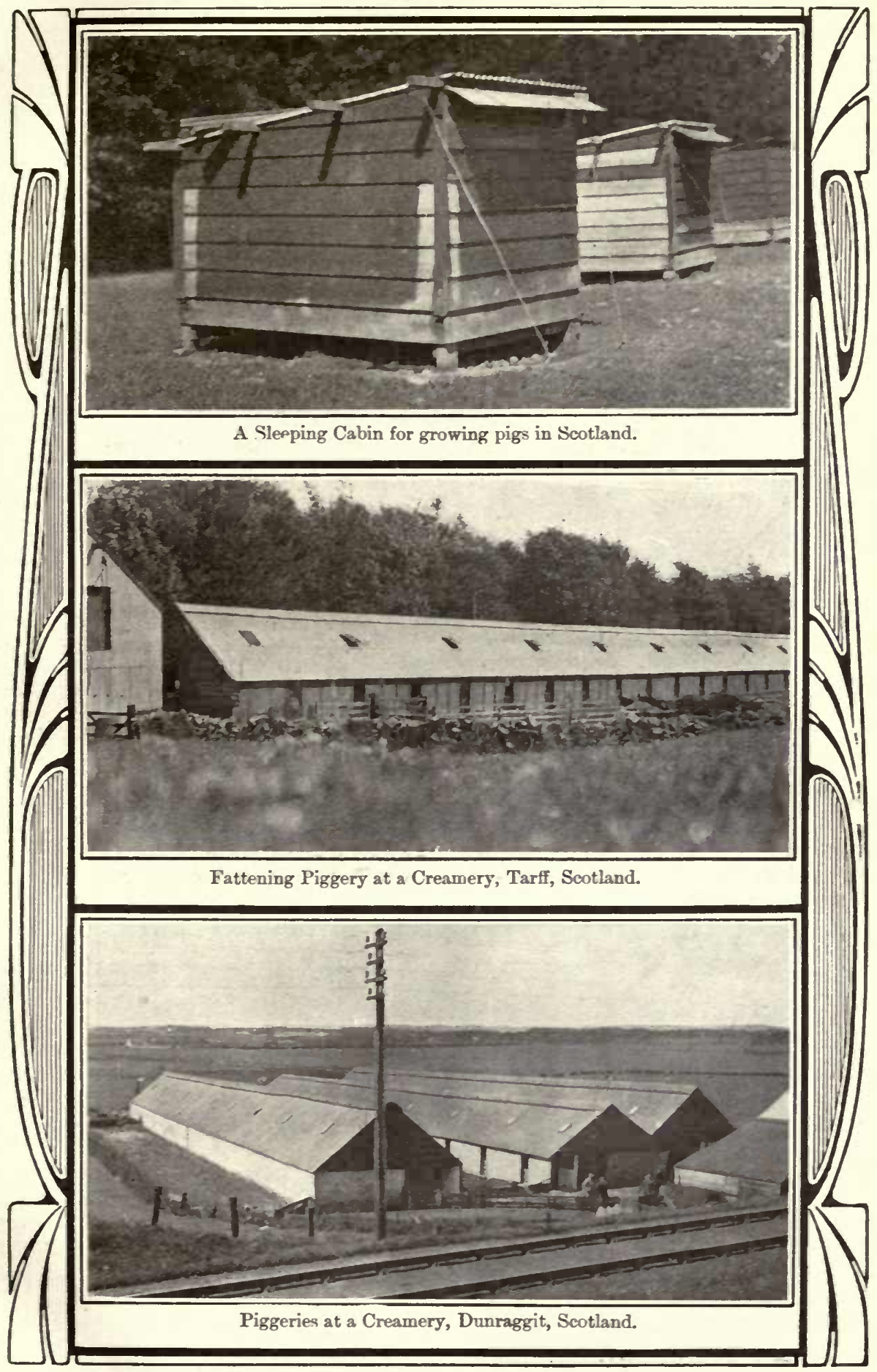




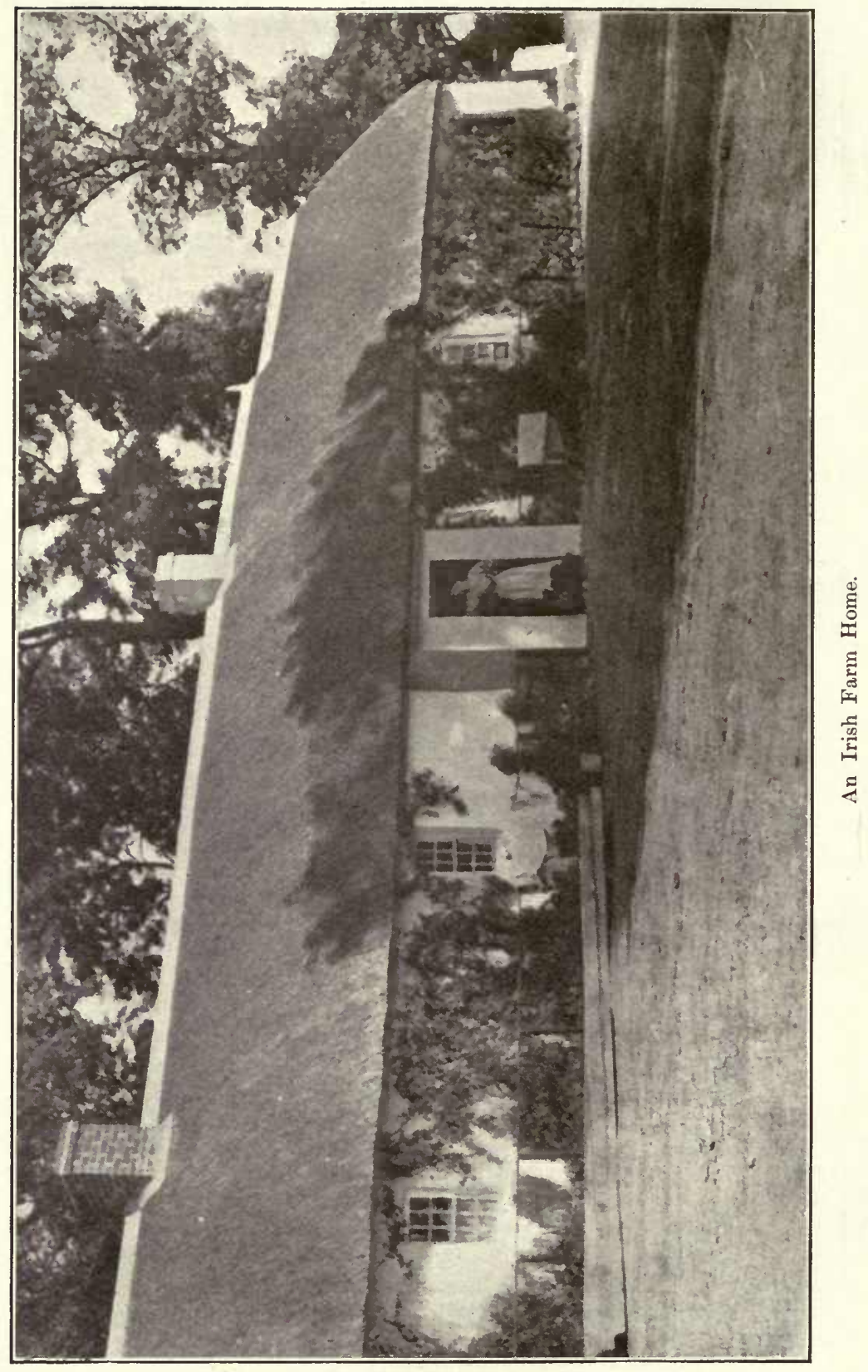




\section{IRELAND.}

Next to Danish, Irish is the strongest competitor of Canadian bacon in the British market. It is many years since Irish bacon gained a foothold as a standard breakfast meat and since the Irish farmers have continued a fairly regular supply of pigs while the curers have kept up the quality of the meat, customers long since acquired continue to ask for and use Irish bacon. It is not therefore owing so much to superior quality as to uniformly good quality and regular supply that Irish bacon commands a higher price than Canadian. During the past summer when Canadian bacon was selling at 73 to 76 shillings per cwt., Irish was bringing 74 to 77 and Danish 76 to 79 . The greater popularity of the Danish is due to milder cure which the Irish curer does not see fit to risk especially during warm weather. Canadian is even more salt than Irish. It has to be made so in order to withstand the longer haul and delay between factory and market.

The production of pigs in Ireland for many years has been fairly constant. 'The figures for 1899 and 1907 are practically the same being a little over 1,300,000 while during this period and including 1908 the number has never fallen below 1,200,000. These figures represent the number of living pigs at the time of the annual enumeration the first week in June.

Pigs are exported from Ireland both alive and dressed, the quantity of the latter gradually increasing. In 1904 half a million live pigs were exported about 26,000 of these being store pigs, the remainder fat. In 1908 the number was 387,476, only about 16,000 of which were stores. During the same years the exports of bacon were 87,405,360 lbs. in 1904 and $104,593,184 \mathrm{lbs}$. in 1908. The exports of pork and hams show less variation which indicates that the pigs of Ireland are being more and more turned into bacon. There are about 35 bacon factories operated on a commercial scale in Ireland and they handle about one million pigs per year. The co-operative movement has set in. One well equipped co-operative factory is in operation in the centre of the country and another is likely to be opened in the southeast at an early date.

\section{The Pigs.}

During recent years the Irish farmer, like the Canadian and Danish pig raiser, has been working towards the bacon type of pig. There are three recognized breeds in the country-the native Ulster, the Yorkshire and the Large Black. As boars the Yorkshires are much in favour, while as mothers the other sorts are very popular. In form and aptitude the Ulster and Large Black are much alike. They are both lengthy and deep of body, have large drooping ears and are hardy feeders, rapid fatteners and the sows make excellent mothers. In order to preserve the Ulster breed in its pure state the Royal Ulster Agricultural Society recently established a Herd Book. Foundation stock was accepted on careful inspection as to breed type and vigour. Already one volume has been issued containing the pedigrees of 54 boars and 166 sows. The Yorkshire has been a favourite in Ireland for many years. In Ireland, as in England, bacon curers have distributed among the farmers a large number of boars of this breed. Before the Department of Agriculture and Technical Instruction was organized, the South of Ireland Bacon Curers' Pig-improvement Association distributed more than 2,000 boars of the Yorkshire breed at a cost of some $\$ 65,000$. 'The result of this distribution was very marked on the type and colour of pigs produced. Heretofore black and spotted pigs were quite general, but the Yorkshire cross has done away with much of this. Now the dark colour is again coming in to the chagrin of some 
of the curers. The good doing qualities of the Large Black appeal to many of the farmers, and the Department of Agriculture, through its premium boar scheme, is distributing many hogs of this breed.

The Department of Agriculture is carrying out an ambitious policy in the interest of swine improvement. Mr. Wood, who has charge of this work, showed the Commission the herds of Yorkshires and Large Blacks, kept at Albert Agricultural College, "Glasnevin,' near Dublin, as well as many boars and their offspring throughout the country. The object of the Department in its schemes is to encourage farmers to keep for service only pure bred hogs of good type. To this end a sum of money is set apart each year to be used as premiums for selected boars registered in the Royal Dublin Society Herd Book. 'The eligibility of a boar for a premium is determined by an official inspector appointed by the Department. Boars of the three breeds mentioned are eligible for premiums of $\$ 25$ for the first year, and $\$ 15$ for the second. To secure the premium for an approved hog, 30 sows must be served the first year, or 45 the second, at a fee of one shilling each. The demand for premium boars is large and increasing, and is frequently greater than the available supply. Practically all of the boars produced by the college herds of Yorkshires and Large Blacks are sold as premium hogs. These are delivered to any part of the country for $\$ 24.30$ per head at five months old. Young sows in farrow are sold at the same price but are not delivered free.

'This scheme for the improvement of swine has been in operation since 1901, when 151 premiums were paid. The number has gradually increased until in 1908 it had reached 340 , which would be slightly exceeded in 1909 . Of these, more than 200 were Yorkshires, about 50 head Large Blacks and about 20 White Ulsters. 'The far-reaching effect of the scheme will be better understood when it is pointed out that about 17 per cent of the boars used in Ireland are premiums boars; and since these are selected from the standpoint of the bacon industry, it must be conceded that Ireland is bound to go forward in the production of fine bacon swine.

In Ireland, as in Great Britain, many of the farmers do not finish the stock that they breed. A much larger proportion of them either raise pigs to sell as young stores, or buy stores to finish. As a rule the man who finishes stock of his own breeding makes the most of his pigs from year to year, but the element of doubt on the one hand, and speculation on the other, induces many to adopt one or the other of the two remaining systems.

The Commission visited many representative swine rearing centres. It was found that the character of the swine, and the manner of their treatment, differed in the north and south. In the north the drooping ear and other characteristics of the Large Ulster are most conspicuous, while in the central and southern counties the Yorkshire form is generally in evidence. In a few districts the spotted and black pigs are again coming in, the result of the Large Black cross, and these are invariably highly popular. It is true that in times of heavy supplies an excuse is frequently made by the buyers to discriminate against the black skins to the extent of a shilling a cwt., but these pigs are such hearty feeders and good thrivers that many feeders are bound to have them. When the markets are bare the blacks go as well as the others.

\section{Housing and Feeding.}

Very few piggeries that would be called good in! Canada were seen in Ireland. At the Albert College, a thoroughly comfortable and sanitary pen is in use, but at most farms visited the pigs are housed in little stys, usually situated at the side of the barn. It is, nevertheless, true that improvement is being affected in this matter by the adoption of ideas on the construction of piggeries circulated in pamphlet form by the Department of Agriculture.

The Irish pig is, as a rule, well cared for. While hardly treated as a pet, it is highly respected and carefully looked after. Where a farmer raises pigs in numbers he is most likely to give this stock his personal care, while in the case of the smaller breeder with one brood sow, she is usually looked after by the wife or daughters. No amount of trouble seems too much to devote to preparing food. Almost all food is cooked and generally fed 


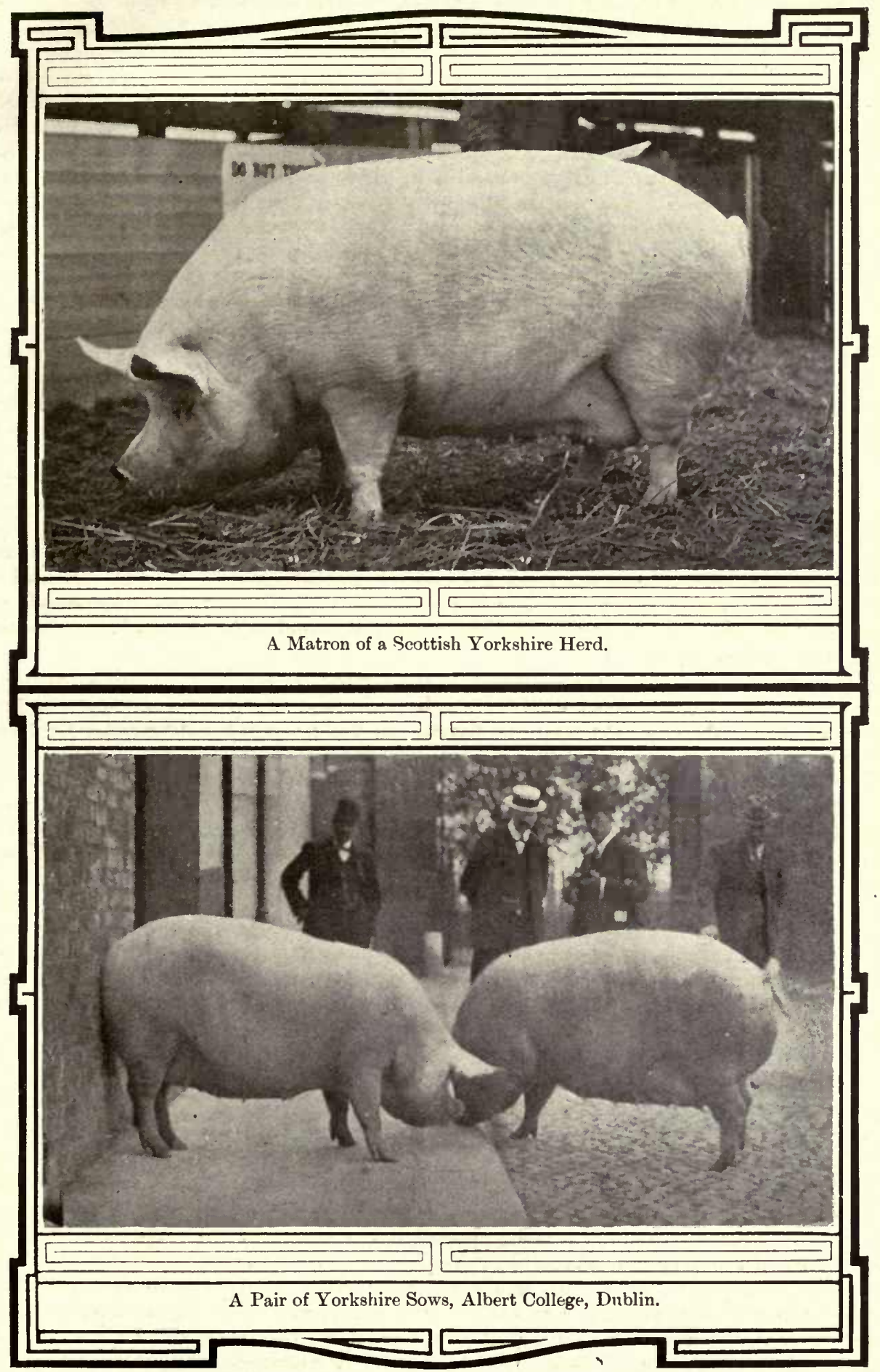


warm. Not many years ago it was the very general rule to allow growing pigs to gather their living outside during summer until the potato crop was harvested, but this is being all changed, so that finishing and marketing is becoming more and more uniform throughout the year.

Two litters a year are the rule, one farrowed in February or March, the other in August or September. In earlier years October was the busy autumn farrowing month, but people have come to see that pigs born so late do not winter well, and then feeders usually buy their winter stock about the first week in November, or earlier, if possible, and consequently there is better demand for young pigs at that time.

Irish pig raisers have learned the wisdom of not weaning too early. From seven to eight weeks is the usual weaning age throughout the country. In the north, the breeders who do not fatten their own stock, usually keep the litters two or three weeks after weaning before taking them to market, where they are purchased by feeders who at once put them on good feed, rushing them along to a finished condition weighing 150 to $175 \mathrm{lbs}$. dressed, at six to seven months old. In the South, the old practice of allowing the young pigs to grow slowly as stores, and turning them off fat at ten to twelve months old is, on many holdings, still in vogue. The tendency, however, in the South, as already mentioned, is to save time by shortening the life of the pig.

While the industry is better conducted by the northern than the southern farmers, the supply of stock in the south is more constant from year to year. This is due to two principal causes: 1st, the more highly developed condition of the dairying industry; and 2nd, the dependence of the Southern province farmers upon the pig to pay the rent. The Ulster farmer is more flexible in his methods, and moves up and down according to conditions. During the present year the continuous high prices for pigs have led to a considerable increase in the number of brood sows kept in the northern half of the country.

Pigs are, as a rule, economically fed in Ireland. Buttermilk and skim-milk are doled out carefully at all seasons of the year, and to this, in winter, is added potatoes and turnips, and in summer, cabbage and other green foods. These form the staple dietary along with corn, barley and oats finely ground and given as a warm mash. As the finishing period approaches, the grain ration often used consists of two parts crushed oats to one part corn meal. At this stage the green food is reduced to a minimum. The method of feeding described is that generally approved by the most progressive swine feeders. As in Canada, all good feeders do not feed alike. The methods on a number of farms visited are described as follows:-

At Albert College the litters are weaned at 9 weeks. At three weeks they are started on new milk and gradually put on to skim-milk with steamed corn meal and shorts added. At weaning time each pig is getting from one to two pints of milk per day, but this is gradually substituted by brewers' grains with a view to cheapening the ration. The practice at the College in winter is to steam potatoes, corn meal and shorts together, enough for two days, giving the food as a slop three times a day at first, and twice a day when the pigs have reached four months. The growing pigs are housed constantly, but breeding stock is given an outside run.

A patron of Roscrea co-operative bacon factory farming 70 acres feeds off about 20 pigs a year. These constitute two litters from each of two Yorkshire sows. These pigs get the skim milk and butter milk from seven cows. The litters are weaned at 7 weeks. When three weeks old they are fed new milk and soon after oat meal with hulls sifted out is added. Gradually skim milk is substituted for the new. At three months old roots and barley meal are steamed together and fed. At first roots comprise most of the ration which is made stronger with meal as the finishing time approaches. In summer mangels are fed until cabbages are ready.

Patron No. 2 owning 10 Yorkshire sows weans at 8 weeks. At 4 weeks the litters commence to get new milk (six quarts per day for 10 pigs) and a week later boiled slop consisting of potatoes, corn meal, barley meal and shorts. The milk fed is gradually changed to separated and fed warm. The sows are turned out each day when the litters are being fed. This patron hangs a lantern in the pen of a newly farrowed sow for two nights to prevent little pigs being killed. He does not consider it profitable to allow a sow to rear

$10489-3$ 
more than ten pigs at a litter. At three months each pig gets 2 quarts of milk in three feeds. This is considered the profitable maximum. At this age $7 \mathrm{lbs}$. of potatoes and $2 \mathrm{lbs}$. of chop are fed daily with the milk. This ratio is continued until the final month when the ratio of grain to potatoes is turned about. Oat chop is highly valued at this period. At no time is more than $3 \frac{1}{2} \mathrm{lbs}$. of grain fed per day. Pigs are finished at six months weighing $170 \mathrm{lbs}$. dressed, equal to $224 \mathrm{lbs}$. alive. By this method of feeding it costs this feeder an average of 8 cents per day per pig. This herd owned by Mr. J. Willington won most of the prizes for Yorkshires at the Dublin exhibition.

A farmer on 70 acres feeds off 30 pigs per year. Litters are fed at 4 weeks and weaned at 7 to 8 weeks. Until 1907 all grain feed was boiled but now soaking is considered just as good. This feeder like previous ones visited does not consider it as profitable to buy as to raise ones own stock. Pigs are fed twice daily on slop. In winter potatoes are cooked but mangles are pulped and mixed with soaked grain chop. Young pigs in August were getting skim milk, chopped cabbage and shorts. They were soon to be turned out to grow up on cheap feed until five to six months old when they would be housed and put on a fattening ration that would make them ready for the market at 8 to 9 months old.

Another feeder Mr. Lyons was loud in his praise of Large Blacks as good doers. He owns a nice herd that were in fine breeding or growing condition. Sows get no food for twelve hours after farrowing; they then get light warm slop consisting of steeped bran sweetened with treacle until in full milk. In ten days they get boiled potatoes, bran, and milk with a light grain ration which is gradually increased. All food is fed cooked and warm. As early as young pigs will eat they got a separate trough for such food as milk, potatoes and shorts. The sows are spayed and the boars castrated at seven weeks and all are weaned a week later. 'They are fed three times a day on milk and shorts. Good feeding is continued until the pigs are sold. Mangels, turnips or potatoes are fed almost the year round and cabbage is given in summer and fall. The first four months after weaning the ration is two-thirds bulky food and one-third chop, the latter being shorts, bran, barley meal and corn meal. The ration is during ten days changed to two-thirds grain and one-third bulky food. During the last three weeks a feed of dry oats (1 to $1 \frac{1}{2} \mathrm{lbs}$. for each pig) is given at noon. Four litters a year from two sows are turned off. Many of the neighbouring farmers feed in about the same way and all are endeavoring to avoid marketing at seasons of heavy supply. One feeder visited would keep five or six sows and sell young pigs if he had more milk, without which he does not consider pig feeding very profitable.

\section{Marketing.}

In the South of Ireland pigs are sold alive, whereas in the North they are disposed of dressed. In the central and southern counties monthly pig fairs-marketsare the medium of transfer, but in the neighbourhood of factories the rule is to sell at these plants Because it is felt that buyers and curers work together to "fix" the price, there is a strong tendency towards co-operative curing which already has a foothold in Roscrea Tipperary County, while a large co-operative concern is soon to commence operations in Wexford. The Commission spent an interesting day at Gorey pig fair. Early in the morning pigs commenced to arrive in carts some hauled by donkeys and others by horses. The carts lined the main streets backed up to the sidewalk. In a number of cases the pigs were unloaded and penned on the sidewalk. The offering consisted of perhaps 800 head, 40 per cent being prime bacon hogs, the others chiefly stores. Buyers were on hand bright and early and by nine o'clock a large number of the pigs had been sold. As a rule much bantering was done before the bargain, which always took into account a "luck penny," was announced by a slapping of the others hand. On that day the price was high but this did not prevent perhaps three per cent of the pigs returning home unsold. This fair presented the Commission with an excellent opportunity to see that old established packing houses discriminate very carefully in selecting pigs for their plants. The price they were prepared to pay for select pigs was announced and such pigs as suited them as they could buy were purchased. Of course there was no bantering in the purchasing done by this firm. The 


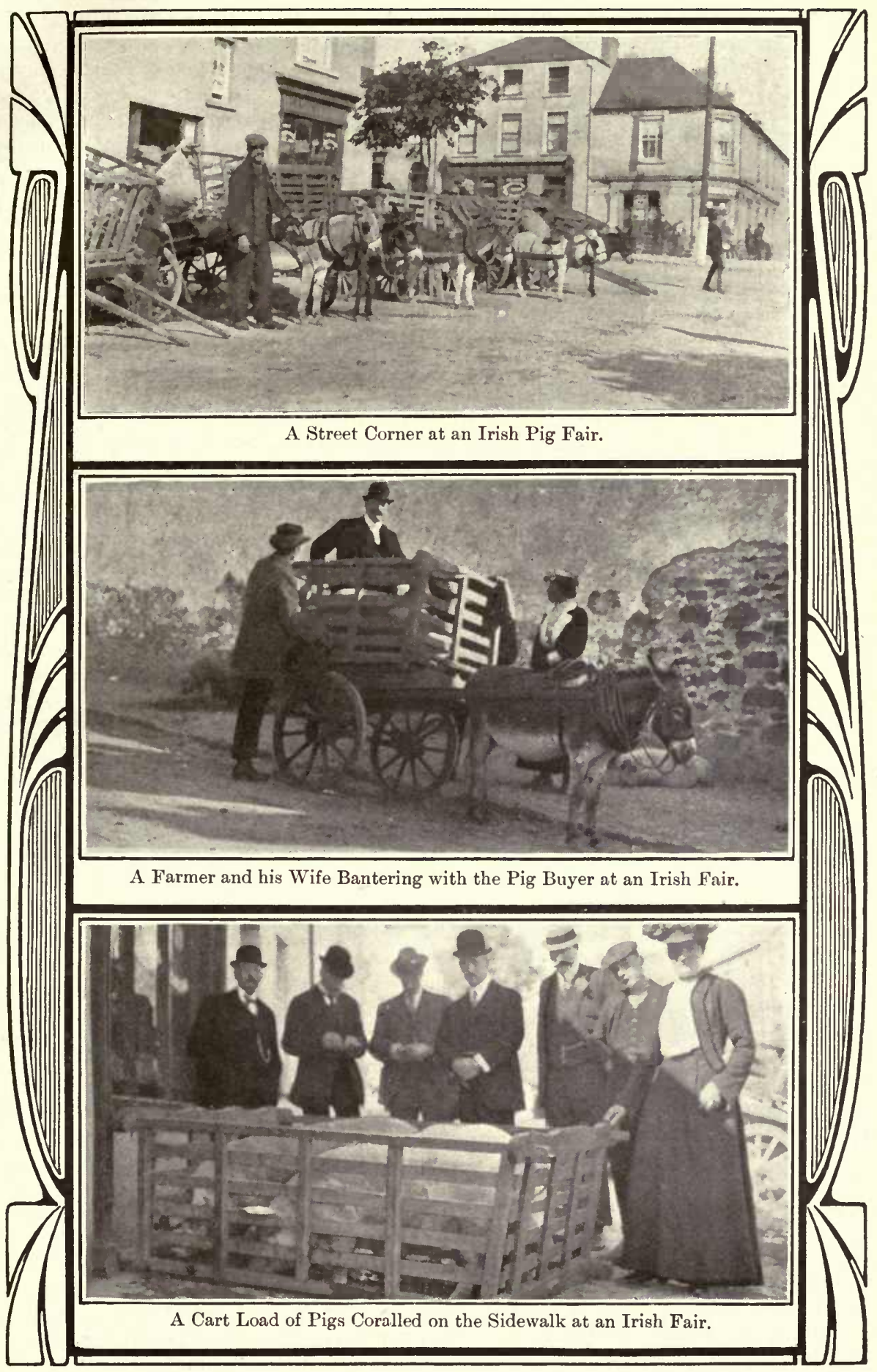



old system of selling at fairs by private bargain is loosing favor as it is felt that buyers who take no risk, have been getting too much of the profit, even more than the packers in many cases. Buying by weight is rapidly coming into vogue and it is felt that it will not be long before markets are conducted as in England and Scotland on the auction principle.

As already stated fat pigs in the northern part of Ireland are sold dressed. They are brought to weekly markets and sold according to weight at the fixed price of the day. In some cases the farmer kills his own pigs while in others the job is done by a travelling butcher who hangs them up at one shilling a piece. This system of marketing is general throughout the North of Ireland. even in towns where pork curing establishments are in operation. This system is satisfactory alike to seller and buyer as the business is done in a straight and open manner, the farmer delivering the goods and receiving the cash as he would do in selling grain, potatoes, butter or other products at the market price without scheming or bantering.

\section{Bacon Curing.}

Irish cured bacon and hams are well known and highly prized in the British market. Many of the curing houses are conducted by old established firms that guard with jealous eye the reputation of their products. They not only select with the greatest care the sort of pig they use, but they exercise great caution in the system of curing followed so as to secure the utmost uniformity in the goods bearing established brands.

To encourage the production of only first-class bacon pigs the old firm of Henry Denny \& Sons distribute freely at markets leaflets of instruction. Following is a copy of a sample leaflet secured by the Commission:-

\section{INSTRUCTIONS TO PIG RAISERS.}

Don't breed from a badly formed, poor quality sow, a portion of every litter reared by such is almost certain to inherit the bad qualities of the mother and when marketed classify as "Unfinished." The best animals, male and female, should be selected for breeding purposes, the results pay better and are more satisfactory every way.

Commence to fatten your pigs immediately after weaning, and if they are well bred and properly fed and attended to, they should scale live weight, about $1 \mathrm{cwt} .3$ qrs. $18 \mathrm{lbs}$. (214 lbs.) at five months old.

The best food is barley meal and milk. An excellent food, and probably the most economical also, is maize (corn) meal, potatoes, and milk in the proportion of two parts by weight of meal to one part of potatoes. The proper proportion of milk to give is from 2 to 3 gallons to the stone (14 lbs.) of solid food, and you cannot fatten pigs profitably without milk.

Separated milk if not pasteurised should be used perfectly fresh, there is no difficulty about this, if the farmer has a separator of his own; keep the vessels scrupulously clean. Separated milk from the Creamery should be pasteurised there. It cannot be too strongly insisted upon that pasteurised separated milk is good food for animals, whereas if not pasteurised, and even one day old, it is in many cases positively injurious.

Among the very worst foods are turnips, mangels, and brewery or distillery grains; they are most uneconomical foods also, having very poor fattening properties. Every pig fattened on these will classify as 'Unfinished' in our hanging house.

\section{CLASSIFICATION OF PIGS.}

Sixes.-These are pigs, sometimes well finished but only weighing live weight about 1, 2, 19 (187 lbs.) and under, and at the time when they are not wanted, it will pay the farmers to feed them for a few weeks longer.

Prime Sizeable.-These are the most suitable bacon pigs, weighing live weight about 1.2.20 (188 lbs.) to 2,0,9 (233 lbs.) and if properly bred, well finished, and hard in the fat, are the most profitable to the Curer, and always command the highest price.

Prime Stout. - The same remarks apply.to this classification that are applied to Prime Sizeable, except that the pigs weighing live weight about 2,0,10 (234 lbs.) to 2,1,9 (260 lbs.) are somewhat heavier and therefore never quite so suitable.

Overweights.- The pigs for this classification weigh live weight about $2,1,10$ (262 lbs.) to $2,2,0$ (280 lbs.) and the bacon manufactured from them is sold for much less money, consequently their value is not so great.

Unfinished.-These are thin, ill-shaped, coarse-legged, thick-skinned, or soft-fatted pigs of all weights, that through being badly bred, badly fed, or both, do not finish properly, and are the opposite to being "well finished" and "hard in the fat."

\section{MARKET ADVICE.}

The proper weight to market your pigs is $1 \mathrm{cwt} .3$ qrs. 18 lbs. (218 lbs.) live weight average, don't burry them out lighter.

HENRY DENNY \& SONS.

Many of the factories are old in design and system of handling hogs, but the newer plants are large and modern in every particular. 


\section{Co-operative Packing.}

In Ireland, as in Canada, swine raisers are not entirely satisfied with the treatment received from the packers. This is more especially true south of the middle line where pigs are sold alive. Learning of the success of co-operation in bacon curing in Denmark, certain districts in Ireland have sought to apply the same remedy. There is, consequently, in operation at Roscrea, in Tipperary county, an extensive co-operative curing house, and it is hoped before long a similar plant will be running in Wexford at the town of Enniscorthy. Before the visit of the Commission the Wexford co-operative bacon factory society had been formed, a prospectus issued and much stock subscribed.

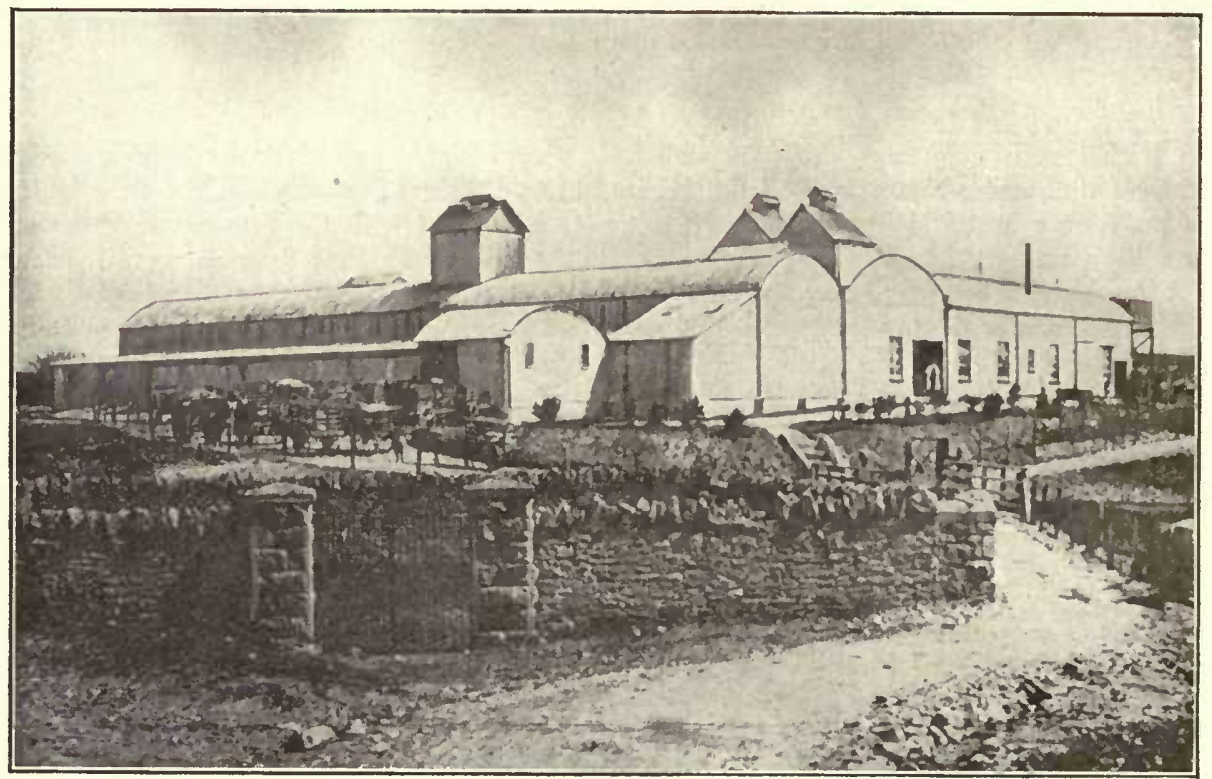

ROSCREA BACON FACTORY.

First Farner's Co-operative Bacon Factory in the United Kingdom

The Roscrea factory has been in operation since early in 1908. It has 4,000 members or patrons living within a radius of 18 miles round Roscrea. Each member must own at least one share of stock, for which he pays one pound, but he may buy as many shares as he likes. Each shareholder is entitled to share in the profits according to the number of pigs he supplies. A statutory rule exists that each member must, under a penalty of $\$ 2.40$ per pig, offer such bacon pigs as he produces, and all of them, to the factory. This ensures a constant supply of the raw material. and also prevents any attempts by outsiders to unduly influence the local markets temporarily, so as to induce pig breeders to send their pigs elsewhere. On the other hand it is laid down that a bonus will be given to pig suppliers according to the number of pigs which they produce. The rules are very comprehensive in character, and are subscribed to in a declaration which each shareholder has to sign, and which forms a definite and binding contract.

The factory is constructed throughout of corrugated iron, which forms the roof and sides, and which is carried on vertical iron columns. The total area covered is approximately $136 \mathrm{ft} . \mathrm{x} 120 \mathrm{ft}$., and the departments are laid out to suit all requirements of such a plant. The capacity of the bacon factory is 600 pigs per week, and the total cost including the land, was about $\$ 37,000$. 
Up to August, 1909, the average run had been 150 pigs per week, the highest number being 211 . The killings would have been much larger but for the fact that the society was short of working capital, and could not pay for more than a limited number of pigs per week. This was due to an error in commencing with too low a capitalization, and strange to say the banks carnot be induced to advance money on the stock. Except for this unfortunate handicap the factory would do a flourishing business, as not infrequently hogs delivered have to be transferred to other houses that can pay for them at once.

The success of such a plant depends much on the management. The Roscrea factory has for manager Mr. J. W. Welsh, who has had experience in successful bacon factories both in England and the United States. Already the bacon made at Roscrea factory has won the highest possible honours at the London Dairy Show. The output of the factory is shipped in bales to representatives in England, who sell direct to the retail trade. As in the case of Canadian and Danish bacon, the meat is not smoked until it reaches the English merchant.

The report of Roscrea Bacon factory for the first year of operation, 1908, shows a good profit to the shareholders. During the year the turnover of business amounted to about $\$ 170,000$, of which about $\$ 43,000$ represents live pigs sold by the factory for the members. After allocating all expenses chargeable to the trading, there remained a net profit for the year of some $\$ 1,500$. The directors in this report point out that with $\$ 25,000$ more working capital the gross profits would have been doubled, while the net profits would have enabled the board to have allocated a substantial sum to shareholders on the value of pigs supplied.

The process of curing at Roscrea is practically the same as that adopted by Canadian curers. The killing and dressing is carried on as in a modern factory in Canada, except that more of the work is done by hand at Roscrea. The sides after being properly dressed, and trimmed, are hung in the chill room, which is held at a temperature of 38 degrees Fahr., and in which a constant current of cold, dry air is circulating at that temperature. The meat is, therefore, reduced to about 38 degrees Fahr., and this process occupies something like a whole day, after which the sides are passed into the curing cellar. In the case of 'Wiltshire' sides they are pumped with a recognized pickle, and are then sprinkled over with curing antiseptic, on the top of which is placed a heavy sprinkling of curing-salt. 'The same process takes place with almost every part of the pig, and on the average about two weeks are allowed for the curing, but of course this is modified according to the character of meat it is intended to produce, Hams, for example, are not pumped and are kept about 21 days in salt. When the meat is cured it is drained free of pickle, and is then removed from the cellar and washed in readiness for shipping.

The bacon is cured almost as hard as Canadian, it being considered that a milder cure as in Denmark, is too risky on account of possible loss through taint if the meat is not quickly consumed.

\section{SETTING THE PRICE.}

Each week a committee appointed for the purpose sets the price to be paid the following week. Each Saturday a postal card noting the prices for the several classes of pigs are mailed to each shareholder. Both live and dressed weights are quoted. When the pigs are delivered they are weighed on a scale which records on a tag the weight in cwts., qrs. and lbs. If the pigs are sold live weight they are paid for at once, but if by dressed weight a tag is put in the ear of each. so that it can be followed through the slaughter house

\section{Instructions to Feeders.}

The Department of Agriculture not only does much to improve the quality of the pigs of the country by means of the premium system already described, but it frequently sends out pamphlets of instruction on breeding and feeding. Following is a copy of a recently prepared leaflet that contains good information for swine raisers !n any country. 
'What is the best type of pig to rear and feed for marketable purposes?

'An animal possessing the following points is considered a type of pig to suit alike the breeder, feeder, and consumer of the United Kingdom:-

'I. - Neat head. The pig that is very long in the head is usually narrow between the eyes, has seldom a very strong constitution, and has rather more bone than is required. On the other hand, the pig that is very short in the head is usually too fat, too heavy in the fore end, thick in the neck, and heavy in the shoulders. Neat in the head means neither too long nor too short a nose. The ears should be fairly large, soft, and pliable, and should fall a little to the front without actually being lopped.

'II.-Light neck and shoulder. The coarser parts of a side of bacon and those which fetch the lowest price are the neck and shoulder. The lighter these parts the better the side and the higher the price it will make.

'III. - Deep heart and well sprung ribs. Pigs are usually deficient in these points, which are, perhaps, the most valuable of those here enumerated. For stock purposes, breeders should, therefore, select only those animals which have these characteristics strongly developed.

'IV.- Thick loins. A pig with a good loin is almost invariably well ribbed, and has a strong constitution. From a breeder's and feeder's point of view, a good loin is most essential.

'V. - Stout thighs. This means a pig thoroughly well developed in the hams. The hams are the most important parts of the animal, and, in the case of pigs killed for the ham and middle trade, the most valuable of all, provided they are not too fat.

'VI.-Short legs. A pig that is long in the leg is nearly always flat in the ham and lacking in plumpness.

'VII.-Long and silky hair. Good hair is an indication of strength of constitution as well as lean meat. The absence of hair generally proceeds from close breeding, and indicates a tendency to excessive fatness.

'VIII. - A long side of moderate depth, with thick flank.

'This type of animal should be aimed at, whether thoroughbred, half-bred, or common bred pigs are kept.

"To produce pigs having the qualities enumerated above, the first consideration must be the selection of the boar. It is said that the boar is half the herd. Even this estimate undervalues his power of reproducing his like. It is, therefore, all-important that a boar possessing the particular points described should be obtained.

'At present the improved Large White Yorkshire and the Large Black appear to be the breeds which possess the required points. A sire of one of these breeds should therefore be selected.

"The pig that commands the highest price is an animal which when well finished and not over fat, weighs 12 stone (168 lbs.) dead, or about $15 \frac{1}{2}$ to 16 stone (217 to $224 \mathrm{lbs}$.) living. A good pig ought to arrive at this weight at the age of seven months from birth.

'In selecting a sow there are a few points which a good specimen should possess, in addition to these mentioned for the boar. The sow should be docile and should have at least twelve teats, of an equal size, and evenly placed well forward on the belly. Sows having large flat teats generally secrete very little milk, and on this account prove bad mothers. The fineness of the hair, skin, and bone all indicate a good quality of flesh, and an animal that is likely to become a good mother.

'FEEDING.

'Pigs should be well fed, but not over fed. It is only when fed regularly that pigs give most satisfactory results to the feeder.

'During the first half of the sixteen weeks which a sow goes in pig she should be allowed to run on grass, and should receive a limited amount of other food. For the last eight weeks she should be treated more generously, so that she may be in good condition, but not too fat, at the time of farrowing. During the time the sow is rearing her litter, she should receive as much good food as she will take, consisting of boiled potatoes, Indian meal porridge, pollard, bran, and skim milk.

At three weeks old the young pigs begin to eat, and at this time should be supplied with skim milk, separated milk, or fresh buttermilk, which may be mixed with a little pollard, bran and boiled potatoes, and given twice or three times daily. For feeding the young pigs a special trough should be provided, whioh should be thoroughly scalded with boiling water every few days. Care should be taken to prevent the young pigs having access to the sow's food. When eight weeks old the young pigs may be weaned. After weaning they should receive the same quality of food in a sloppy condition, and be allowed a little exercise.

'When the pigs have reached about $1 \mathrm{cwt}$. in live weight, the amount of exercise allowed them must be limited. The food should now consist of boiled potatoes broken up and mixed whilst hot with a quantity of raw Indian meal and pollard, or barley meal. After the pigs have eaten as much as they appear to require, a small quantity of buttermilk, skim milk, separated milk, or kitchen refuse should be added, to induce them to clean up all the food given them. The quantity of food which a pig should receive is just what it will eat up clean, no more and no less. Turnips and mangolds are sometimes used instead of potatoes, but potatoes give by far the best results.

'When being fattened, pigs should be fed three times a day. The food ought to be brought to a temperature of $90 \mathrm{deg}$. F., by direct heating or by the aid of hot water. By so doing much of the food is saved in the animal's body for the production of fat.

'The addition of oats to the food of pigs which are being finished improves the whiteness of the fat and makes the flesh firmer. The pigs should therefore receive oatmeal or bruised oats during the three or four weeks previous to the time at which it is intended to kill the animals. During this period they should be allowed neither turnips nor mangolds. When the food contains a large proportion of brewery or distillery by-products the fat produced is soft and of a yellowish colour, and the meat is not of good flavour. The excessive use of such products is therefore to be avoided.

'Every farmer should try and breed the store pigs he requires, because, in the first place, a pig eight weeks of age should not have cost more than $8 \mathrm{~s}$. (\$2.00) to produce, whereas more than double this amount has generally to be paid in the open market for such a pig. Furthermore, pigs reared on the farm fatten more readily, and are therefore more economical than pigs bought in the open market.

'Great care should be exercised in keeping the houses in which pigs are kept clean and comfortable.

'('leanliness of the sties and feeding of pigs on suitable food are quite essential if the animals are to be kept in a healthy condition.' 


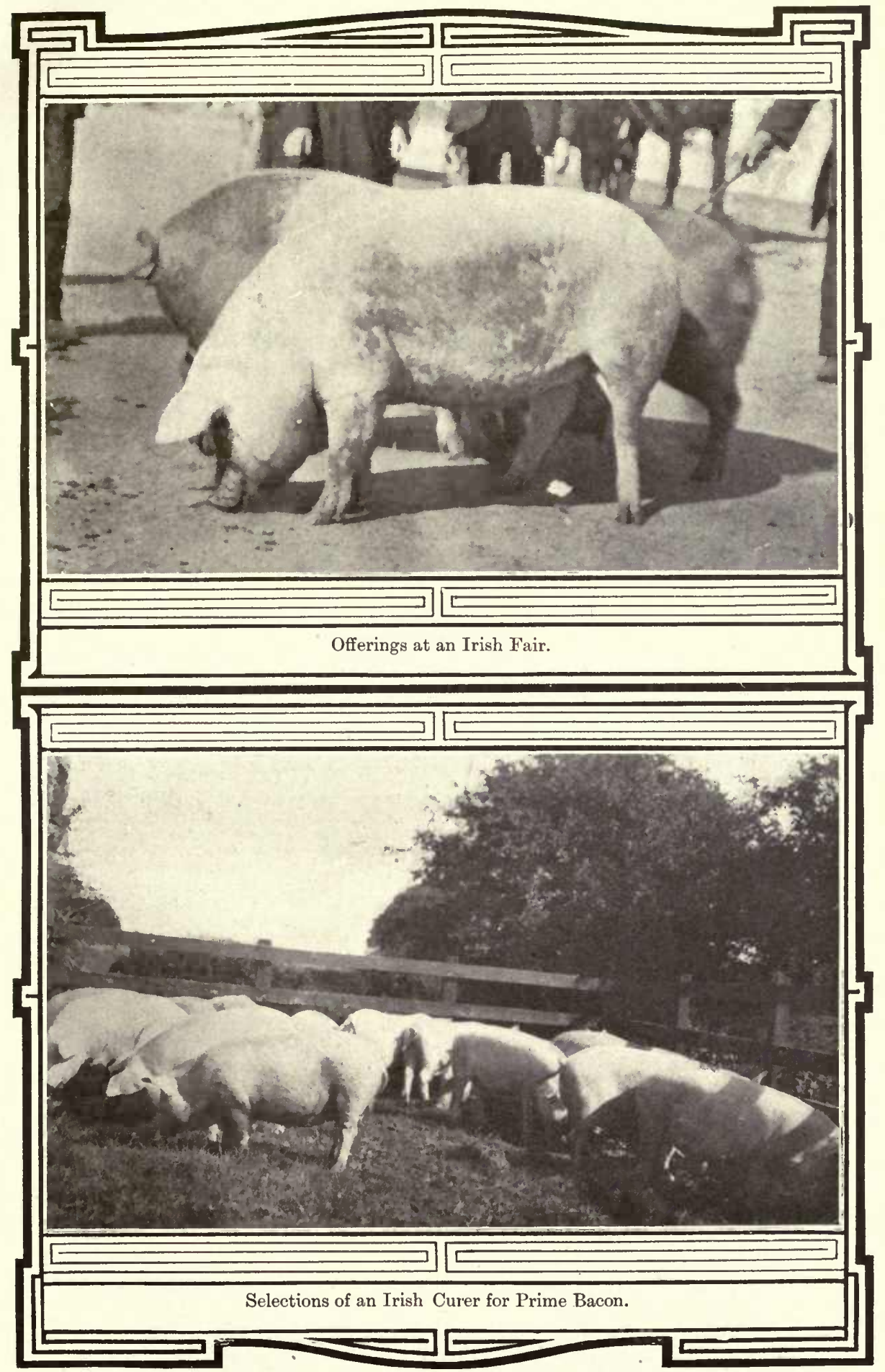





\section{Recapitulation.}

The present and expected future success of the swine rearing industry in Ireland may be attributed to the following condition :-

1st. The rearing of swine is a popular branch of Irish agriculture. Nowhere throughout the rural districts do the people despise the pig. Both extensive farmers and the more humble of the rural classes find it profitable to raise at least a small number of pigs each year. The frugal habits of the Irish peasant admit of no food refuse or damaged crop being wasted. The careful feeding of these together with a greater or less quantity of purchased food stuffs materially helps to maintain many a small holding. The "gintlemin that pays the rint" means much more among the frugal Irish folk than perhaps any other class or race of people.

2nd. Pork is a popular meat on the tables of those who can afford to use it in Ireland. Buttermilk and potatoes with pork form a popular combination among the poorer classes in Ireland whether the three are used as a diet for the family or the two former combine to make the last named product. The meat of the hog therefore finds a wide demand at home.

3rd. The proximity of Ireland to the British market has for very many years proved a keen impetus to pork production. The great manufacturing centres of England require constant supplies of pork products. Irish packers and English merchants have long since come to regard each as indispensable to the other. The Irish packer has been wise in his day and generation. Not all the pork he ships bears his most cherished brand. Much

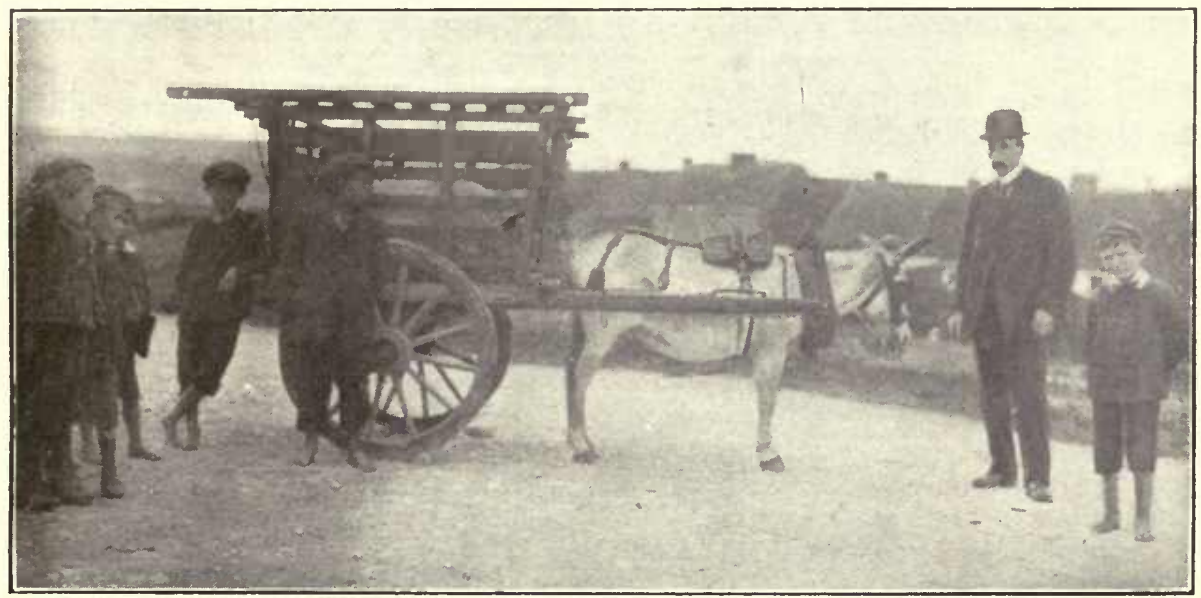

A Shartholder's Delivery, Roscrea Bacon Factory.

Irish pork such as that from old breeding stock, over fat hogs and those that are too thin are sold without indentification, but no business man guards with keener jealousy the reputation of his special brands of bacon and hams than the Irish curer. From the great mass of supplies he selects most carefully the pigs that are to be cured for the best trade. 'The curing is done with equal care and at the end of this stage only the firm sides and lean plump hams receive the first brand. On this kind of combination Irish bacon has established itself in Britain and on a continuation of this the trade that is won is held.

4th. The Irish farmer inclines to follow a leader in whom he has confidence. This characteristic of the people is of great assistance to the Department of Agriculture in its work in aid of swine improvement. Already this has helped the quality of Irish pigs. Cooperation too, finds a receptive soil under such conditions. This is getting a foothold in many parts of Ireland not so much in bacon curing as yet but in the buying of supplies needed in the homes and on the farms and the marketing of farm produce. Co-operative curing has commenced and will grow to the undoubted advantage of the Irish pig raiser more especially in the direction of producing "Wiltshire" sides for the British market. 


\section{DENMARK.}

Denmark affords an interesting field of study for any class or body who may undertake to investigate any of the several branches of agriculture followed by her people. To properly understand swine husbandry, as carried on by the Danish farmer, it is necessary to known something of the condition of the country, its rural population, and the general system of agriculture followed.

A glance at the map of Europe will show that Denmark is a comparatively small country occupying a rather exposed position surrounded almost entirely by the cold and stormy waters of the North and Baltic Seas. The Kingdom, consisting of the peninsula of Jutland and the Islands of Fyen, Zealand, Laaland, and a number of smaller ones, occupies an area of about 15,000 square miles, equal to about two-thirds of Nova Scotia, one-half of New Brunswick, or one-fifth of Manitoba. The profile of the country often reminded the members of the Commission of parts of Ontario. The surface is either rather flat or gently undulating, the highest point being only 550 feet above sea level. On this account it is exposed during a long winter season to harsh, sweeping winds. The summer season, always short, is frequently cool. During July the Commissioners found light overcoats necessary when driving about the country. The summer of 1909 was, however, claimed to be unusually cool.

The soil is anything but rich, in fact the country possesses more poor than good land, much of it being thin and gravelly. Of the total area eighty per cent is productive. and of this one-sixth is forest. Of the remainder less than half is arable, what remains being chiefly grass land. The coolness and shortness of the growing season brings problems to the husbandman. In average seasons only the early variety of oats ripen properly and this naturally, limits the field of agriculture. The experiment stations have been trying to develop a fall oat and to some extent, have succeeded, but the general farmer must still depend upon the early sorts of the spring sown kinds. Fall rye, fall wheat and barley do well, and when to these are added oats, hay crops and roots the round of crops which the Dane at home can grow with advantage is about complete. Denmark is therefore not a grain exporting country. Her conditions have proved more favourable for that higher sphere of agriculture, the production of live stock, for which large quantities of food stuffs are annually imported.

Denmark has a population of practically $2,500,000$, nearly one-fifth of which is absorbed by Copenhagen and its suburbs. Dividing the remainder of the subjects of King Frederick into urban and rural dwellers we have about $1,500,000$ on the land. Denmark having no mineral or timber wealth depends for its prosperity upon agriculture. The industry of Denmark is and has in the past been that of farming, and since ninety-five per cent of the population is native born it naturally follows that the system of agriculture is not only highly developed but fairly uniform over the country. It is the one business of a serious, industrious, and educated people, and has lessons for perhaps every other agricultural country of the globe.

Up to well past the middle of the last century Denmark reached a state of comparative stagnation with the effect of starting from the country a fairly strong exodus to the towns and to foreign lands. Aroused by the apparent danger of national decline a strong movement looking to the improvement of agricultural conditions was inaugurated. At that time the exports were comparatively little. The expansion of the export trade in the leading products to Great Britain alone during the past few years demonstrates the progress that has been effected in the general agriculture of the country. The following table shows in dollars the value of the respective products named exported by Denmark to Great Britain during the years indicated:- 


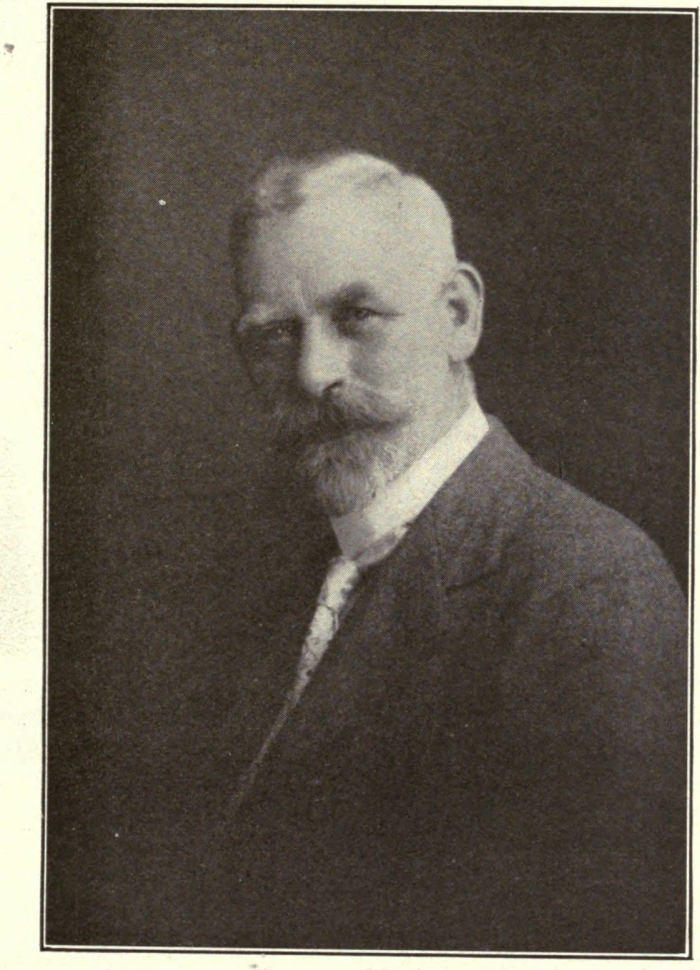

Mr. Peter Aug. Morkeberg,

Government Commissioner for Swine and Red Danish Cattle, Denmark. 

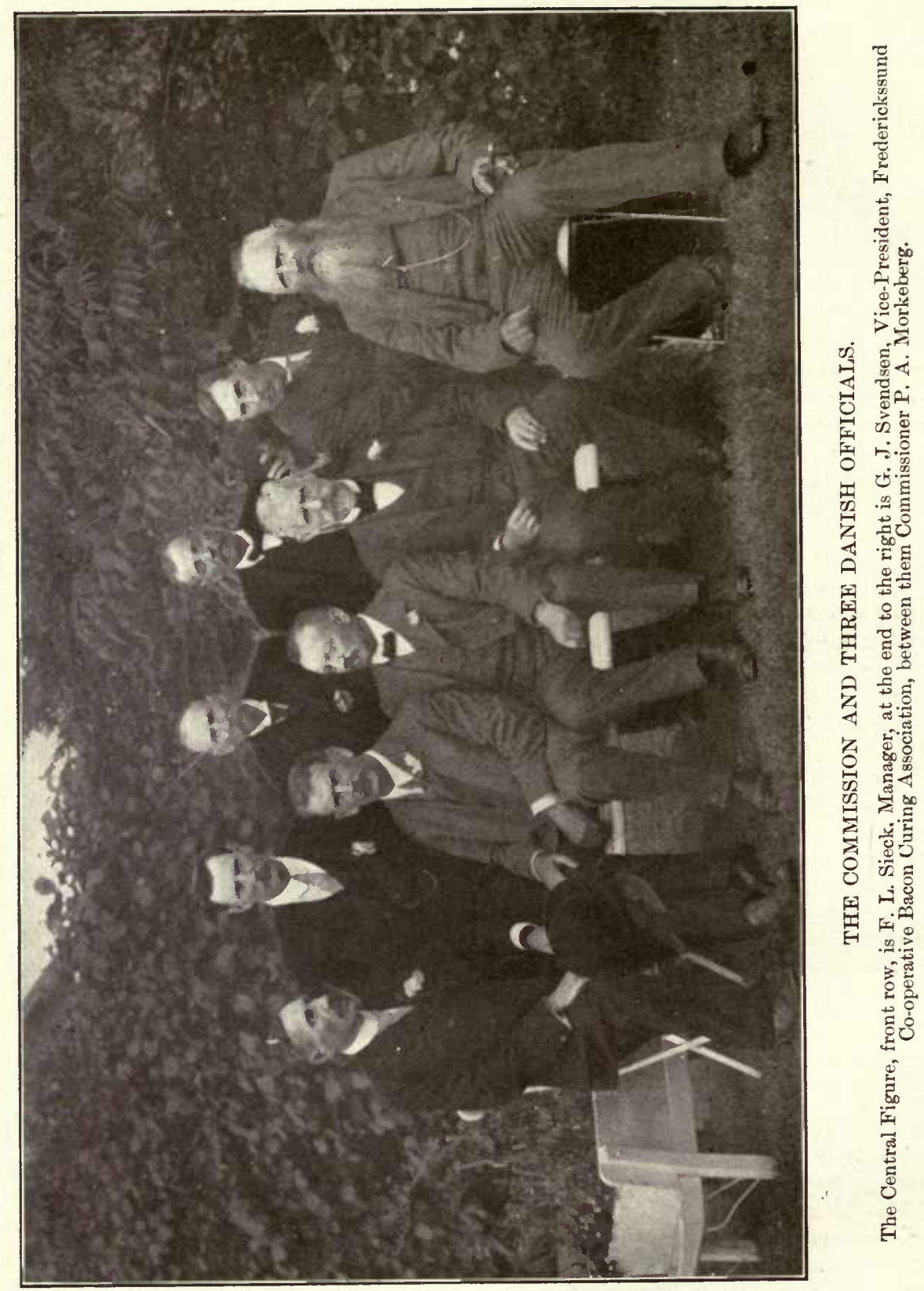


\begin{tabular}{l|r|r|r|r|r|r}
\hline \hline & \multicolumn{1}{|c|}{1899.} & 1901. & 1903. & 1905. & 1907. & 1909. \\
\hline & $\$$ & $\$$ & $\$$ & $\$$ & $\$$ & $\$$ \\
Butter......... & $36,709,698$ & $43,499,415$ & $46,522,053$ & $43,350,063$ & $49,535,972$ & $49,836,611$ \\
Eggs........... & $3,934,379$ & $5,642,207$ & $8,011,063$ & $7,942,639$ & $8,623,185$ & $8,270,862$ \\
Bacon.......... & $14,316,379$ & $15,719,456$ & $20,868,922$ & $19,334,620$ & $26,172,436$ & $28,252,730$ \\
\hline
\end{tabular}

\section{The Educational System.}

The Danish farmer is an educated man. He receives not only an excellent public and high school education, but a large per cent of the tillers of the soil attend agricultural schools. Attendance at the public schools is compulsory between the ages of seven and fourteen, inclusive. Nature study is a prominent feature of the work. Some schools are provided with school gardens, while in the case of others the children are carried freely on the state railways to the country where lessons are given direct from nature.

Over ten per cent of the population pass through the high schools, of which there are more than seventy in Denmark. Both men and women attend at ages from sixteen to twenty-five. The fee for instruction is comparatively low, and provision is made for the state to defray even this in the case of deserving young men or women who cannot afford to pay their own way. The instruction given at these schools is not designed to teach applied sciences, but rather to develop personal character, to brighten the intellect, and to inculcate principles of integrity, thus preparing them for the battle of life that is keen, not only in all trades, but in agriculture as well.

The early high schools took up agricultural chemistry and other sciences underlying the practice of agriculture. The importance of these subjects led to the establisling of purely agricultural schools, of which there are forty-four. Fifteen of these are entirely separate from high schools, one is purely a dairy school, and twenty-nine are closely associated with high schools. Pupils range from eighteen to twenty-five years, and, as in the case of the high schools, they board at the institution. These schools, like the high schools. although receiving small government grants, were erected and are conducted by private enterprise. To secure these schools in many cases farmers, chiefly small proprietors, subscribed to the funds from which they were built and equipped. A farm of greater or less area is attached to most of these schools. This is run on a business basis and serves as a demonstration of the value of scientific methods. All of the ordinary farm crops are grown, and live stock of the several classes are kept. At these institutions men are trained to farm, there being no examination and no certificate granted. There are throughout the country a number of agricultural experiment stations taking up such work as the comparative tests of various varieties of grains, clovers, grasses, mixtures. methods of cultivation, times of sowing, etc. 'The reports of these institutions are eagerly studied by agricultural students, as also by the rank and file of Danish farmers.

The higher agricultural educational work is done at the University at Copenhagen, known as the Royal Agricultural and Veterinary Institute.

The Commission had a profitable visit to this well equipped and renowned institution, under the direction of the Principal, J. Hoffman Bang. This is a magnificient college standing amongst the foremost of its kind in the world. It is conducted by the state for the training of teachers in agricultural and veterinary science, also the better fitting of men to conduct large farms. Many sons of prominent farmers train at this institution to go home to manage their own establishments. The attendance of students in agriculture proper, including dairying, is from 125 to 150 per year, while about an equal number attend to study forestry, horticulture, surveying and veterinary science. The course in agriculture is for two years, but an additional year's course is provided for advanced students who 
wish to qualify to teach agriculture. From year to year about fifty per cent of the graduates of this college return to the farm.

From the foregoing it must be concluded that the Danish farmer, by education, is well fortified for his calling; withal, he is industrious to a degree, deeply in earnest, and eminently practical. His methods, in all that he does, reflect these qualifications. Whether it be in dairying, hog raising, or poultry keeping, he works hard and to good purpose, grappling with problems as they arise, eliminating what he finds unprofitable and constantly pressing forward to a higher degree of excellence in the products of his labours.

Farming in Denmark is conducted on a more intensive system than in Canada. Dairying, and pork production are the chief branches of agriculture engaged in. These, it has been found, are best suited to the country and the energies of the government and the people have been directed towards their development.

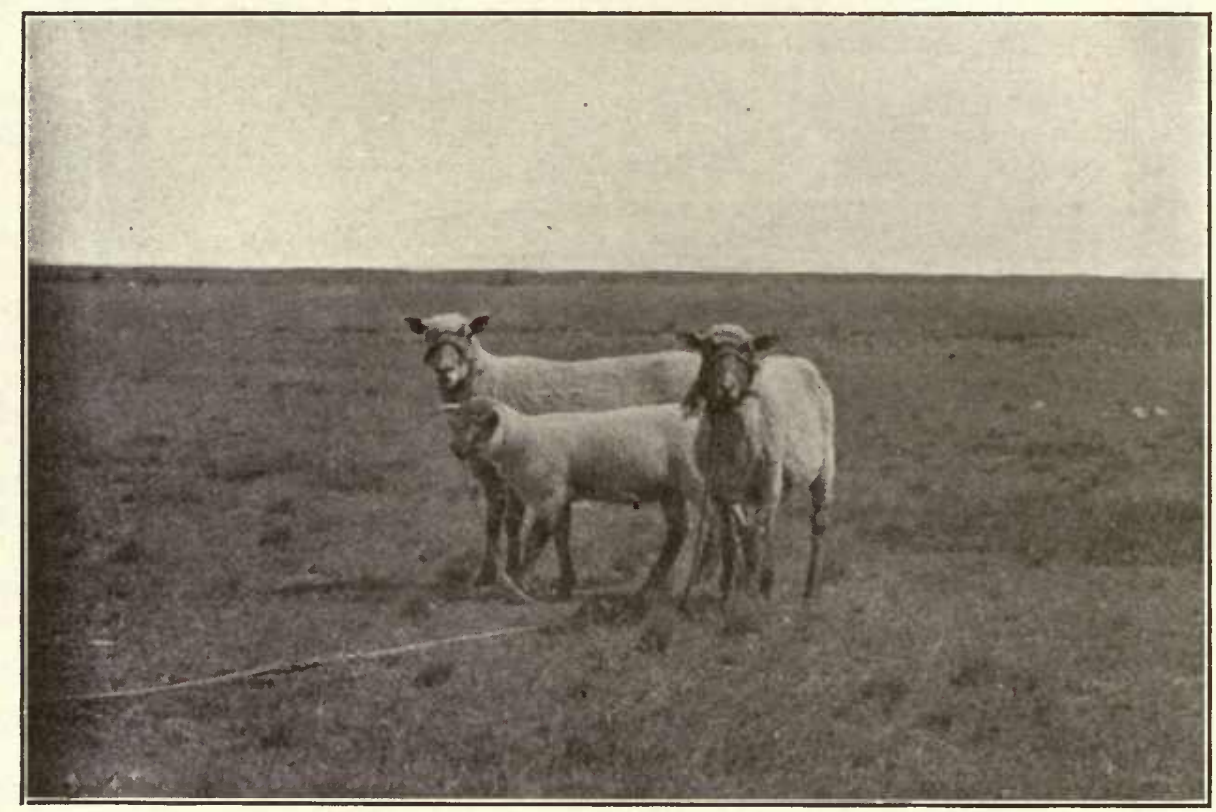

Even the sheep in Denmark are tethered.

Throughout the districts visited, practically all the arable land is under a regular rotation system of cropping. Permanent pastures are not used, in fact, pasturing is not depended upon to any great extent. No stock is allowed to roam over the fields; the cattle and, in many sections, even the sheep are tethered when out of doors. Consequently there are very few fences either dividing the fields or even the farms. Usually a bank about two feet high marks the boundary between farms.

About half the grain crop is oats, the remainder being chiefly barley and rye, with a small proportion of fall wheat. Roots, hay and other fodder crops bulk large in the returns from the land. The aim is to grow feed and the rotation is managed with that in view. On some of the farms visited fully twenty per cent of the acreage was in roots, chiefly mangels for the cows and the pigs. The following table gives the general rotation formula throughout Denmark:-



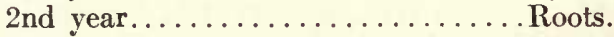

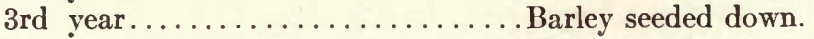

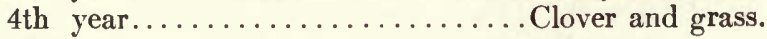



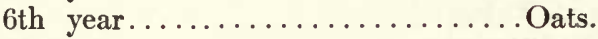

7 th year.................... Fodder plants, lucerne, etc. 






With all these crops heavy yields are the rule. All the crops grown, and much that is bought, is fed to the stock, and occasionally fertilizer is purchased also. The greatest possible care is taken of the manure. Each barn has a manure pit, lined with cement, into which all kinds are dumped. Then all the liquid from the stables is drained into a cistern which is pumped out and applied to the land which is well cultivated.

Labour, though not cheap, is sufficient and of fairly good quality. Most 100 acre farms keep two, three or more men the year round. These get about $\$ 100$ each and their board. Women of the labouring class work in the fields and barns. A large number of Polish women work on the farms of Denmark each summer for a wage of fifty cents per day and board themselves.

While pig raising is a prominent and valuable branch of Danish agriculture it stands second to dairying, which is the chief branch of farming. Butter for the British market is the first object of the farmer, and this leaves a tremendous quantity of by-product in the form of skim-milk. Without this most of those visited considered pig raising could not be profitably carried on. Everywhere skim-milk, or whey, constitutes a portion of the swine ration, the number of swine fed largely depending upon the size of the milking herd. About two to three pigs per cow is the rule on many of the farms visited.

\section{The Pigs.}

Great care has been taken to build up a suitable pig for the purpose intended. Systematic efforts have been, and are being made, to improve the stock from the standpoint of the breeder and feeder, and above all, for the requirements of the British market. The Department of Agriculture has taken hold of this work with vigor and has already accomplished much. The farmers themselves working hand in hand with the Department are making strides in the direction of more profitable pigs. The spirit of co-operation has a firm hold of the people and, through this, almost all middle men between the producers and the British merchant have been dispensed with. The line connecting the man on the land with the ultimate purchaser of the bacon is practically continuous, and, since a bad market reflects almost directly upon the pig raiser, every effort is made to insure a good market all the time. It is a realization of this condition that keeps the Danish farmer keenly alive to the quality of his pigs.

Prior to 1887 most of the Danish pigs and pork exported went chiefly to Germany. Since then live pigs have been excluded from that country. The Danes at once set about the securing of another market. For a year or more shipments were sent alive to England, but the trade was not satisfactory. The British pork and bacon market was then investigated and after learning what was required co-operative curing was commenced. In 1888 the total pigs of the country was 771,000 , and of these 23,000 were put through the first cooperative curing house. The move was seen to be promising and has gone forward until the country to-day has 36 co-operative, in addition to some 24 proprietory factories in which are slaughtered annually upwards of $1,500,000$ hogs per year.

While Continental Europe was the outlet for Danish pigs and pork no attempt at improvement in the quality of the stock was considered necessary. So that when the English bacon trade was undertaken the Danish pig was a coarse rough animal carrying considerable fat when ready to market. Up to this time the English Middle White had been used for crossing purposes, but this was seen to be no longer suitable. A study of the industry in Britain opened the eyes of the Danes to the qualifications of the Large White and since then the blood of this breed has been largely used. The native pig, the "Landrace," was a hardy animal and an excellent mother, and has been retained and improved by every possible means. This and the Yorkshire soon became the only recognized breeds of swine in the country. By means of breeding centres, breeding societies, agricultural fairs, and experimental feeding stations a systematic effort is being made to develop the swine of Denmark to the greatest possible degree of excellence. 


\section{Breeding Centres.}

The Government takes a prominent part in all schemes undertaken for the improvement of stock. The full time of several officers is given for direction and supervision, and grants of money are contributed towards the work. To systematize the work the country is divided into seven districts. Each district is managed by a Commission of three men. One member is appointed by the agricultural society in the district, one by the co-operative pig curing society, and the third, who is the secretary of the Commission, is appointed by the Government. The Secretary of the Commission is responsible to the Live Stock Commissioner of Denmark, P. A. Morkeberg, who organized and directs the whole work. Through this organization breeding centres are established and controlled. These centres are simply breeding farms so stocked and managed as to insure the production of only high class breeding stock. When a farmer wishes to have his farm established as a breeding centre, or when a community desires to have a breeding centre established on a particular farm, he or they make application for such to the local agricultural society. This society by a committee inspects the premises and, if conditions as regards equipment are suitable, the matter is so reported to the Government. 'The Commission in charge of the district then makes an examination of the stock, and if this is found to be of pure breeding of either Landra or Yorkshire breeds, and of good quality, the breeding centre is established. The Committee make careful note of the vigor, uniformity, and breed type of the pigs, having in mind always the production of large litters of strong pigs capable of making first class bacon at low cost. Each centre is visited at least once a year by the Commission, and as often as possible by the Secretary who makes careful note of all details useful to the Department in its work of administration. No centre is recognized which has not been on trial under the local agricultural society one year. The recognized centres have to submit to an inspection by a veterinary officer and must stop the sale of breeding stock if contagious disease is discovered among the animals. The owner must keep an accurate record of the breeding, number of pigs born, number weaned, and the disposal of each. If at any time the Commission find sows or boars used for breeding that are not up to the standard it has power to forbid the produce of such being sold for breeding and, if thought necessary, to close the centre as a Government recognized and subsidized institution. 'The Government assists the breeding centres to the extent of 45,000 kroners $(\$ 12,000)$ a year. This is divided according to the merits of the stations and stock, and the number of animals sold. The policy of the Department in assisting breeding centres is to enable them to sell to farmers young pigs of high quality for breeding purposes at a reasonable price. This for two-months pigs is generally 25 kroners $(\$ 6.50)$ each. For older stock the price is correspondingly higher, but what may be termed fancy prices are not permitted to be charged.

There are scattered over Denmark 95 breeding centres for the Landrace breed and 20 for Yorkshire. The former have 121 selected boars and 683 selected sows; while of the Yorkshires there are 27 boars and 143 sows. These centres are operated under 66 agricultural societies.

The breeding centres, it will be seen, are a wide spread movement recognized and patronized as the chief source of improved breeding swine. The movement has had a rapid and popular development. In 189867 centres were in operation with 68 boars and 351 sows. 'The numbers have gradually increased and are still growing. An examination of the reports of the Live Stock Commissioner show that while a small number of centres have ceased to exist as such many have continued from the beginning until the present day. During the ten years ending August 31st, 1908, there were sold of the Landrace breed 21,601 sows and 5,427 boars. The total number of Yorkshires sold is not available but during 1907-08 it reached 555 boars and about an equal number of sows.

The members of the Commission visited several centres for each breed. They were most hospitably received and entertained. The uniform excellence of the stock was pronounced. They were given to understand that great improvement and increased uniformity had been brought about in the native breed during the past five of six years. While coarseness and unevenness have been greatly diminished the qualities of motherhood and stamina, for which the breed is famous, have not been sacrificed. 


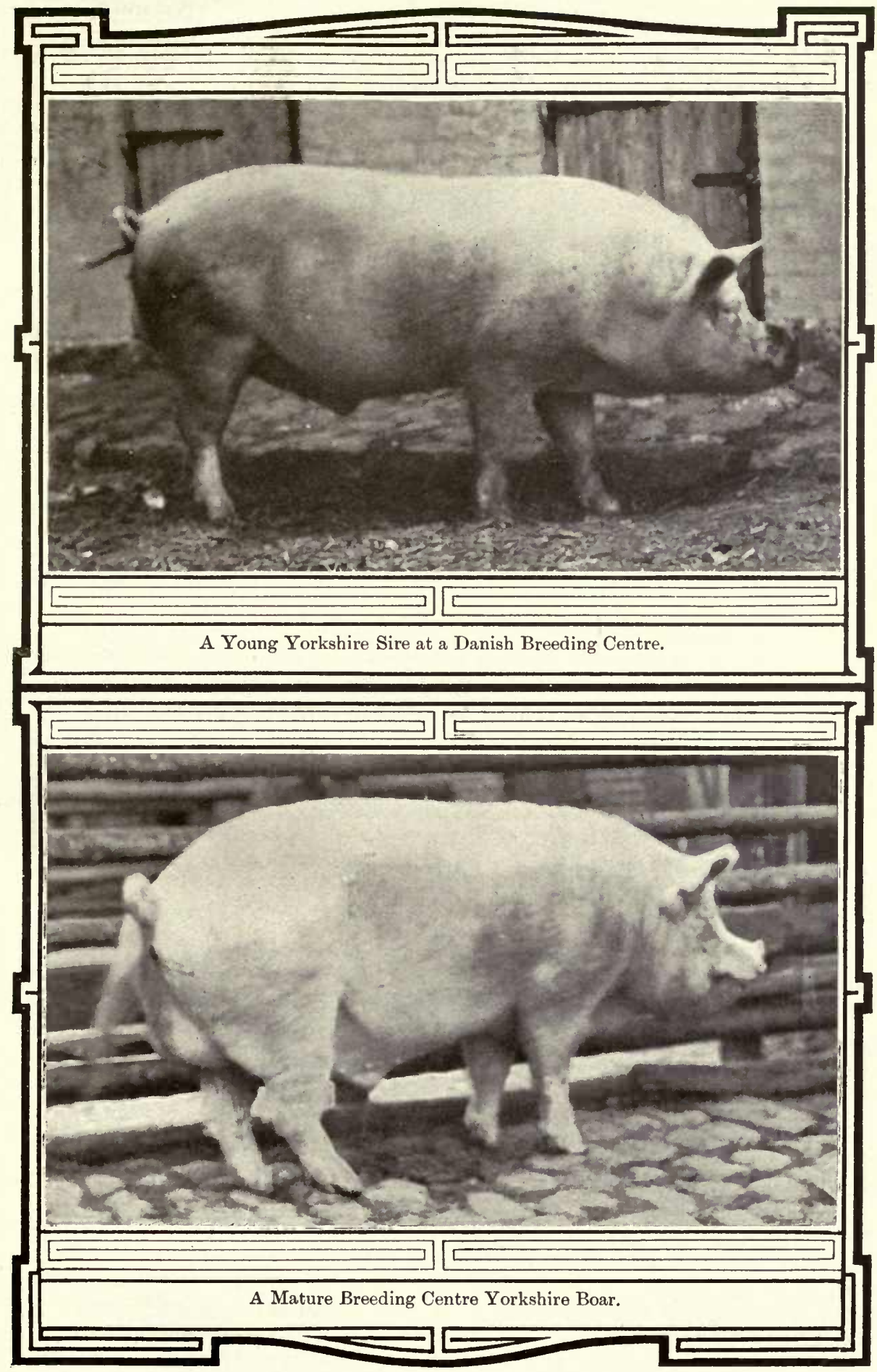




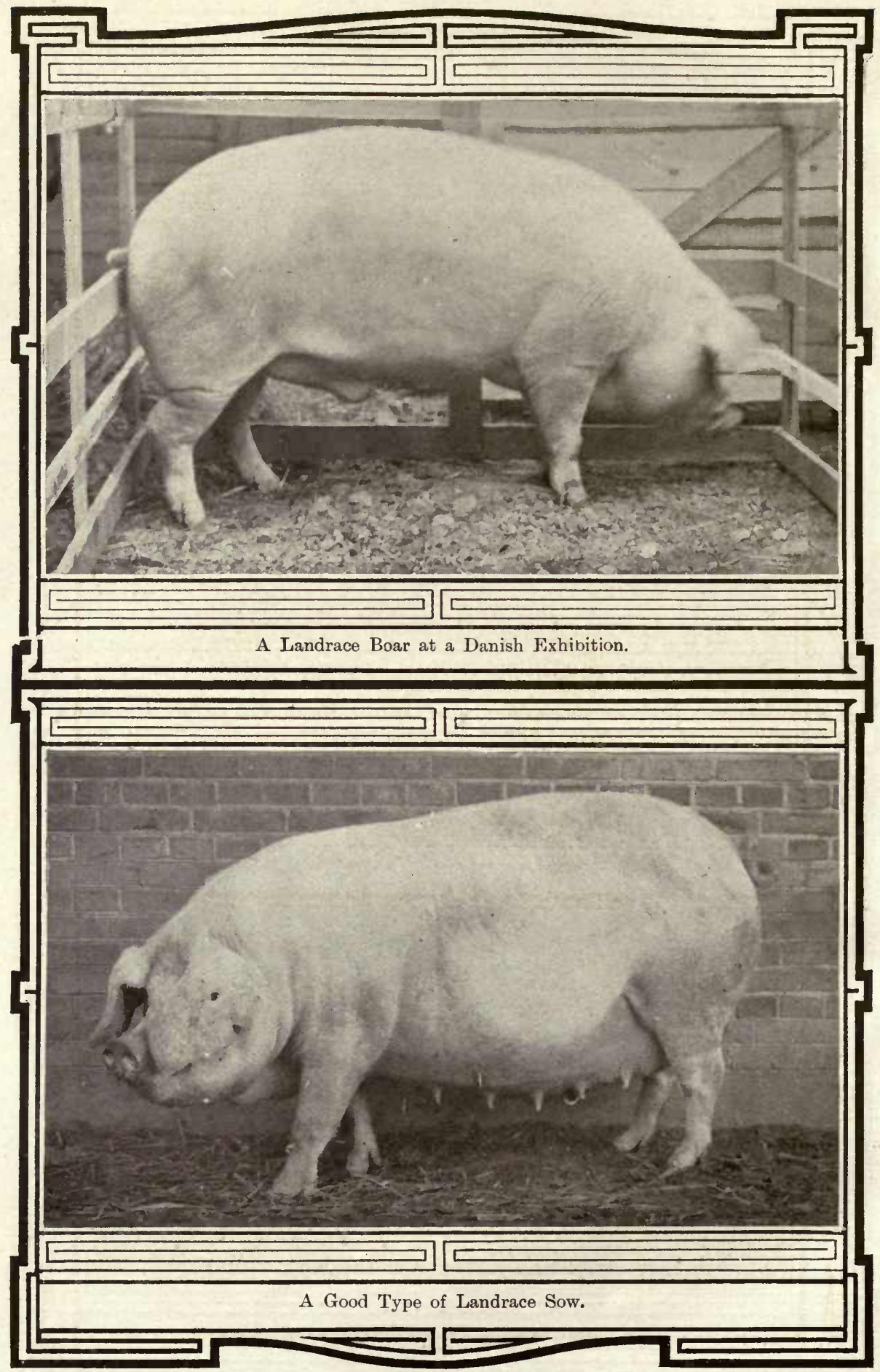




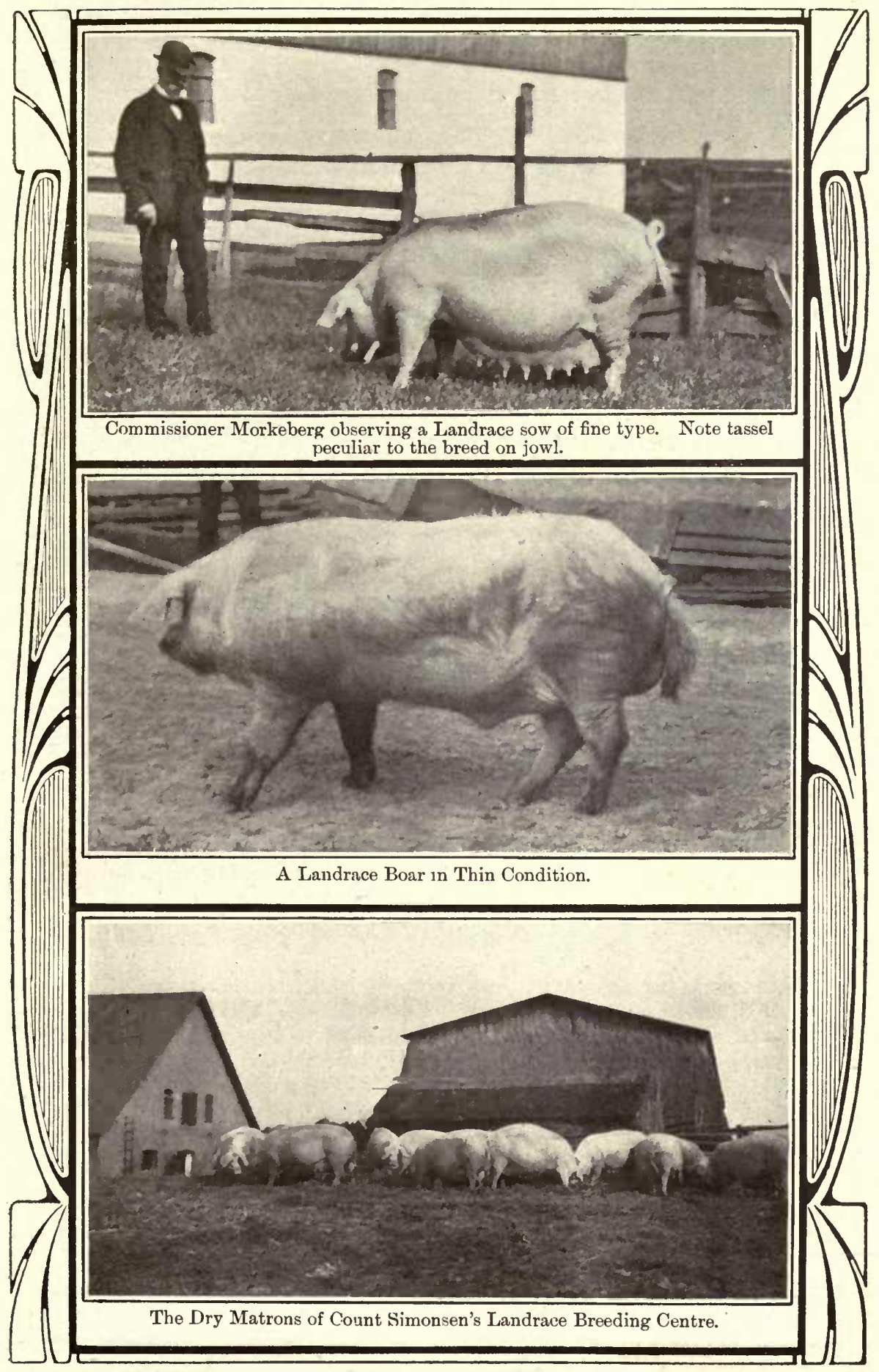



When the centres were established nothing definite was known of the ancestors of the foundation stock. Many animals were therefore selected that proved unsatisfactory breeders. By the system of keeping records followed, the poor breeders were gradually dispensed with. Good families were discovered and when the services of specially good boars had to be dispensed with, exchanges between centres were made. By this and other means the stock of the centres has reached a high standard. The secretary of the central committee for each district keeps a pedigree journal of all the stock under his supervision.

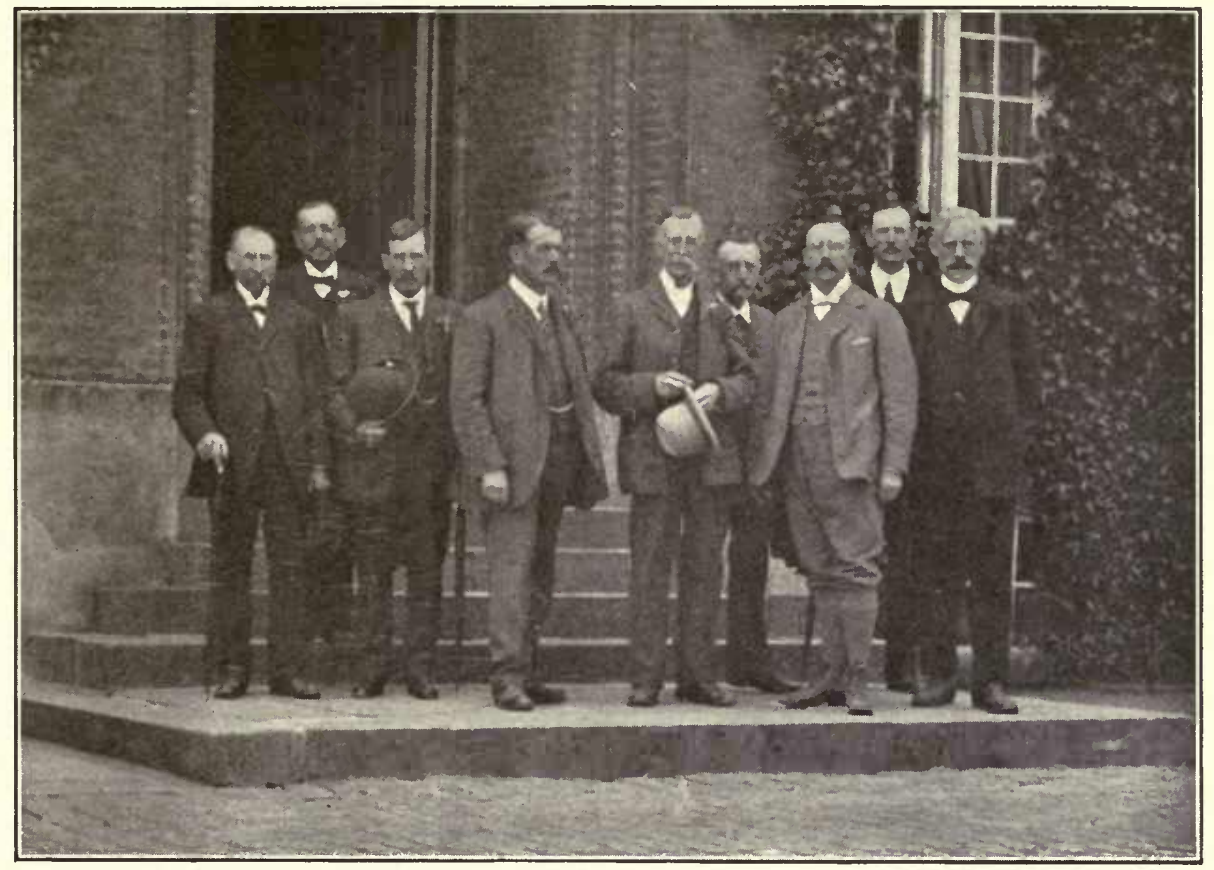

THE COMMISSION AT THE HOME OF COUNT SIMONSEN, AARUP, DENMARK.

Included in the group are Count Simonsen, Commissioner Morkeberg, his assistant Mr. Petersen, and Sanders Spencer of England.

The work of the Department to maintain and develop vigor and prolificacy has been productive of good results. The records show that in the year commencing October 1, 1906, a total of 1,700 litters were farrowed, comprising 18,093 pigs, of which practically 80 per cent of vigorous pigs were weaned. The records from which these figures were taken comprise the yield of each and every sow kept for breeding at the breeding centres. These are kept by the owners of the herds, they are recorded by the secretary of the district committee and transferred by him to the Department at Copenhagen. Unless a sow proves a good mother she is discarded and sent to the block. The statistics for the two breeds kept show the native sows to be somewhat more prolific and vigorous than the Yorkshire. In one district, which is taken to fairly represent the conditions over the whole country, 93 native sows weaned 19.3 pigs per sow in two litters during one year, while 25 Yorkshires weaned an average of 16.2 pigs.

Pigs sent out from the centres are watched as far as possible. Replies from purchasers of 338 sows showed that 79 per cent of first litters consisted of 9 pigs or more; 80 per cent of sows were good milkers, 93 per cent were attentive mothers, and further that 89 per cent of 338 were ready for the slaughterhouse at the age of from 5 to 7 months. The above data has reference chiefly to sows of the native breed. Information regarding boars sent out is 
also secured and recorded. It is shown that in 1906-07 236 boars sent out were bred to 17,124 sows, and that 82 per cent of the boars did well; 94 per cent of the offsprings are described as exceedingly good. It will be seen that no pains are spared to improve the native breed in every possible way. So much attention to the Yorkshire breed is not considered necessary as this sort is looked upon as having been brought to a high degree of perfection in England. Boars of this kind are sent out chiefly for crossing on the native sows, and in almost every case the results are satisfactory.

\section{Swine Breeding Societies.}

Swine breeding centres are owned and operated by individual farmers. In addition to these there are societies formed here and there in Denmark for the object of helping the cause of swine breeding. Of these there were in 1907207 associations, each receiving a small government grant. These societies kept 282 boars for service, of which 154 were Yorkshire and 128 native. Each society has about 25 members, each owning an average of about two breeding sows. These societies get the boars from the breeding centres. By this agency individual farmers are relieved of the necessity of keeping stock boars. He much prefers to become a member of a pig breeding society, and for a less premium than he would otherwise pay he obtains the services of a selected boar, and has the additional advantage of expert advice as to the most suitable mating.

Information concerning the work of these societies is collected. It is shown that 845 litters from native selected boars contained 8,785 pigs, of which 7,322 were weaned. 307 litters from Yorkshire boars contained 3,441 pigs, and of these 2,852 were weaned.

Reports concerning a large number of the offspring of Landrace and Yorkshire boars delivered at packing houses show them to have classed respectively as follows :-

\section{Landrace.}

27.9 per cent class 1 ,

32.7 " " 2 ,

$39.3 \quad 4 \quad$ " 3 ,

$0.1 \leadsto 44$.
Yorkshire.

38.3 per cent class 1 ;

24.5 " " 2.

It will be seen from all this that in Denmark nothing is too much trouble that would tend to improve the pigs, both from the standpoint of breeding quality and that of suitability for the British market. The Department is constantly alive to the question of improvement, and having the very general co-operation of the farmers throughout the country. rapid advancement is made. Following is a copy of the regulations governing the co-operative management of swine associations and swine breeding centres:-

(1.) The object of the co-operative management is to promote swine breeding, swine breeding societies, etc.

(2.) The owners of the recognized breeding centres who are guided by the laws and regulations of the co-operative agricultural societies may, by writing to the president, become members of the co-operative management. Each society is represented by a member.

There is no annual stated subscription; possible expenses are levied upon the members according to the number of sows raised.

(3.) The management consists of, members elected at the annual meeting, from whom the president is elected.

(4.) The executive committee meets as often as the president thinks necessary, or upon request of three members. Resolutions are carried by a majority but are not legal unless three members are present at least.

(5.) In October, November, December or January of each year a meeting is called at which the United Swine Breeding Societies are invited. At the meetings reports of the business of the past year are read. Plans of campaign for the coming year are discussed and elections of representatives made. Any question brought up by a member must first reach the president in writing. 


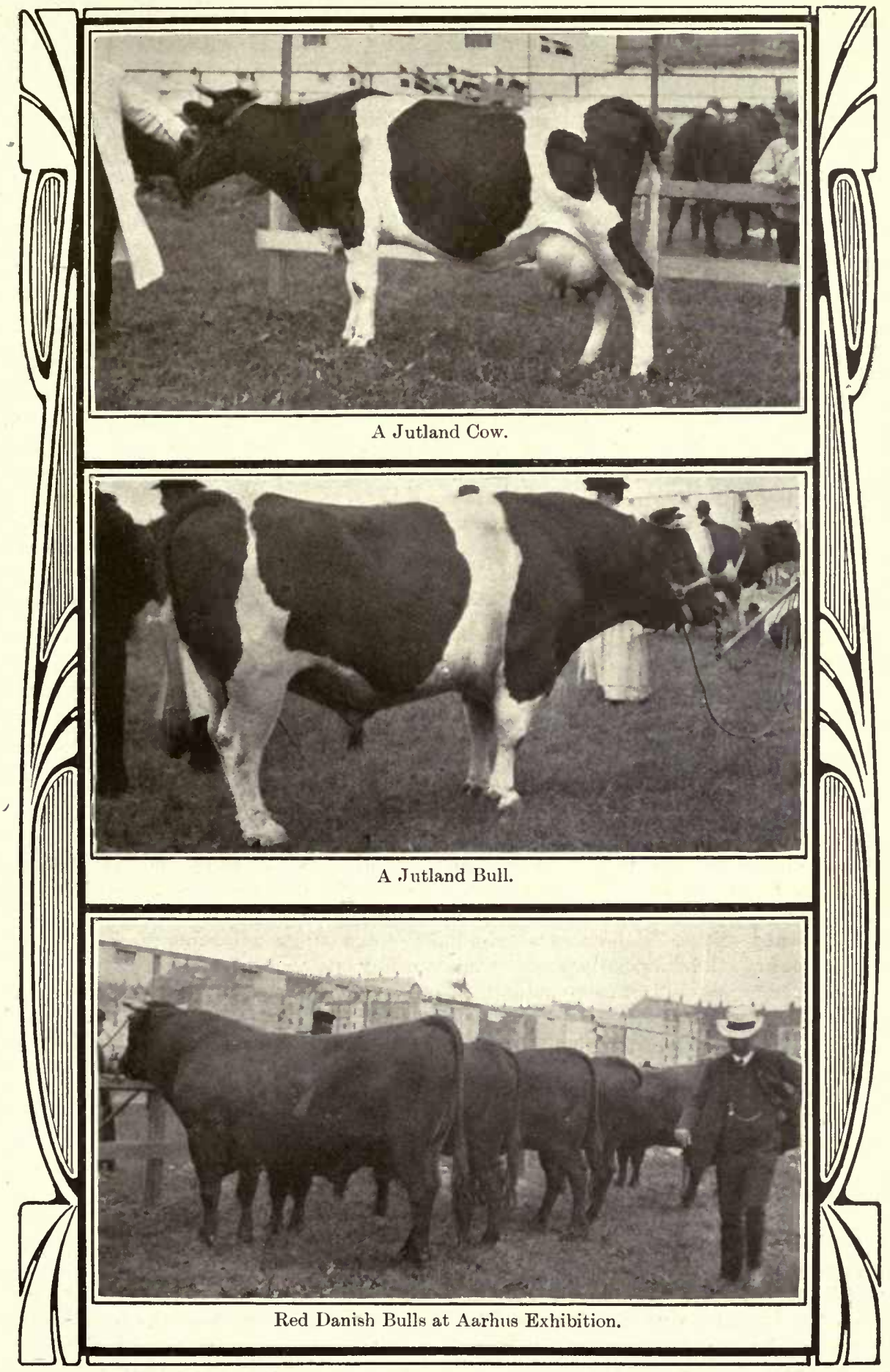





\section{Exhibitions.}

Swine in Denmark have been much improved through the agency of the agricultural exhibitions. Up to near the end of the past century the exhibits of swine at these fairs were very small, while the classification took no account of breeds. At the Jutland Provincial Fxhibition the numbers increased from 78 in 1901 to 303 in 1907. Other large exhibitions show a corresponding increase. Up to 1894 pigs were classified as (a) pigs for fattening purposes and $(b)$ pigs for killing purposes. Then came the division into classes for domestic (Landrace) and Yorkshire, the large exhibitions one by one adopting this classification. Then catalogues commenced to be improved until at the present time the pedigree of each exhibit is published. The Commission were impressed with the evenness of the swine shown at the several large shows attended. They also agreed that the ideal bacon type as recognized in Canada is the form sought at these exhibitions. The system of judging differs widely from that used in Canada. It is not done by comparison but by points. Each animal is scored by an expert who takes into account the development of the different parts, giving a corresponding number of points for each. All the pigs that reach a certain number of points receive first prize, and so on. This system it will be seen encourages large exhibits and prevents the awarding of first, or even second prizes to inferior animals as is often done at Canadian shows. Then in the case of mature breeding stock account is taken of the excellence of the offspring. This feature gives an unfitted good breeder a fair chance against highly conditioned stock. It was pointed out to the Commission that practically all of the stock shown had a direct origin in breeding centres, which have come to be regarded at the main source of all good pigs.

\section{Extracts from Year Book.}

The following translation from the Year Book of Denmark for 1909 summarizes important features in regard to various movements in promoting the swine raising industry:-

(1.) Judging committees for the pig breeding centres.-Certificates for pig breeding centres are given once a year by a committee of judges appointed by the Minister of Agriculture, one member of the co-operative agricultural society of that district and one representative from the various pork-killing establishments. The members are elected for a period of three years.

(2.) Swine breeding centres.-In directing swine breeding an effort is being made to perfect a domestic breed which comprises hardiness, size, build, production of milk, as well as to give large and healthy litters, also to use the large white Yorkshire breed, and by a single cross produce a superior animal. This method will be used until the Danish domestic breed will entirely satisfy the producer as well as the market. According to law of May 23, 1902 , diplomas are given as a mark of distinction by the committee of judges. The Department of Agriculture, upon recommendation, will grant financial aid to the various breeding centres. To obtain a diploma and a government grant the animals in the respective breeding centres must be under the control of the committee of an agricultural society for one year and consist of at least one boar and three sows.

(3.) The United Danish Co-operative Pork-killing Establishment.-This body comprises 33 establishments and its objects are to guard their interests with regard to the regulations put in force by the Government as to transportation and the export of the products, also to make an effort to better the quality of Danish pork.

The representatives consist of three members for each establishment and meets once a year, in the month of March, when a general meeting takes place. The annual expenses are levied on the various establishments according to the number of animals killed, and amounts to from one-quarter to one-half cent per pig, in all about $\$ 4,000$.

(4.) The United Pig Breeding centres and societies in Jutland.-The object is to work in a general way for the promotion of pig breeding. Any member of the following bodies may become members:-The Agricultural Judging Committee for pig breeding centres, owners 
of centres under control and representatives of pig breeding societies. A meeting of delegates is held once a year, when questions of general interest are discussed. The society embraces fifty pig breeding centres and forty pig breeding societies. 'The annual fees are $\$ 1$ per centre and 50 cents per society.

(5. ) The co-operative management of pig breeding societies and pig breeding centres in the province of Fyen.-The object of this body is to promote the development of pig breeding, pig breeding societies and pig breeding centres. Any owner of recognized breeding centres may take part. Each breeding society is represented by one member. The annual meeting is held in the month of December or January.

The co-operative management consists of forty-one pig breeding centres. 'The annual expenses are levied equally according to the number of sows.

(6.) Co-operative slaughter houses.-The slaughter houses are usually owned by the shareholders. They elect the executive committee, from which the president, and vicepresident are chosen. The work is under the direction of a manager, who must report to the executive committee. The annual surplus is divided among the shareholders according to the number of pounds delivered (killed pigs). 'The number of co-operative slaughter houses are thirty-six (36), with about ninety-five thousand $(95,000)$ shareholders. In addition there are twenty-four (24) private slaughter houses, making the total number of slaughter houses sixty (60).

\section{Feeding Experiment Stations.}

It is not enough that the stock kept at the breeding centres be themselves good individuals and the sows regular breeders and good sucklers. Sows are valued on all these points, but unless their offspring fatten profitably and yield carcasses suitable for the British market they are condemned as unworthy of a place among the matrons of a recognized breeding farm. To aid in the effort to bring pig breeding into a more rational channel, and, at the same time, endeavour to produce bacon up to the standard of the British market, feeding experiments were undertaken in the year 1899. To this end feeding stations have been established in each of the provinces of Denmark. 'The Commission visited one of the stations to which was attached an extensive and well equipped piggery. Pigs of the domestic breed, the Yorkshire, and first crosses from Yorkshire boars are fed to ascertain conclusively which of the three reach the slaughter house weight in the shortest time, and, when killed, produce the inost valuable carcasses for the export bacon trade. The experimental animals are, in the case of pure breds, secured from the breeding centres. To secure the stock a committee of three go among the centres and select the produce of such sows as they may clecide upon. Four pigs of a litter are taken for a feeding test. Only average pigs are used. The price allowed is 10 kroners (about $\$ 2.65$ ) each, half of which is paid by the experiment station and half by the local co-operative packing association. The pigs are delivered at eight weeks old. Each group is fed the same mixture according to age, a careful record being kept of the whole work. At each station a feeding master is engaged, his duties being to weigh the exact quantity given each group and to look after the details of the feeding. The groups are regularly weighed. At stated intervals a representative of the department calls, weighs the pigs and takes samples of the food for chemical analysis. The food is weighed out daily, mixed with skim milk or whey and divided into three meals. It is given as a slop, slightly sour from fermentation. Feeding is done at certain hours three times daily, as much being given as satisfies the appetites and no more. The temperature of the air, outside and in the piggery, and of the food is taken three times daily, and for groups of about the same age the temperature is made as uniform as possible.

As the pigs reach suitable weights for the slaughter house they are delivered and slaughtered at a packing house, and when the carcasses have cooled they are thoroughly examined by an expert committee in regard to conformation, taking into account length and evenness of back and sides, thickness of fat and lean, smoothness of shoulder, thickness of belly, form of loin, and firmness of meat. The judging is done in a manner much the sarne as is followed at the several Canadian Winter Fairs. On the opposite page an illustration appears showing a number of carcasses suspended for judgment. These were examined and photo- 






graphed by the secretary of the Commission at a packing house at Ringsted. The expert judges consist of managers of slaughter houses, slaughter house inspectors and a representative of the Department of Agriculture attached to the laboratory of agricultural experiments.

The ultimate object of the feeding test and the judging of carcasses is to determine the breeding quality of the dams at the breeding centres. The record of each group during their career at the feeding station, together with the reports of the carcass judges are traced back to the respective dam and sire, which are valued accordingly. A sow that falls below a required standard as shown by her offspring, is condemned for breeding purposes and sent to the block. As a result of this, one of the stations visited has twenty-six breeding sows, all descended from the same dam.

\section{Summary of Experiments.}

The results of feeding and killing tests over the whole country as summarized by the Department of Agriculture shows that, comparisons between a large number of the pigs of the Yorkshire breed, pigs of the domestic breeds and cross breds, between sows of the domestic breed and boars of the Yorkshire breed have shown that the Yorkshire animals use less food for the production of one pound of pork than the cross breds, and these again slightly less than the domestic breed.

As to quality, an even number of pounds of live weight of the Yorkshire breed has given a larger amount of export pork and less loss in killing, also higher points on the judging than the domestic breed. The cross breds stand much similar to the Yorkshire breed.

In the case of the domestic breed, considerable difference is found amoung the groups but by collecting these groups in generations it has been found possible to judge each line of the generations, and in nearly every case there has been an indication that the consumption of food to one pound of growth is on the decrease from generation to generation.

The percentage of loss in killing is decreasing and the percentage of export pork is increasing from generation to generation.

In giving points for the quality of pork, etc., a decided improvement has been found from one generation to the following.

\section{The System of Feeding.}

Pigs fed at the experiment stations are weaned at from six to eight weeks of age and are at once delivered to the station. At the station pigs are divided into four groups according to weight. Class 1 includes pigs up to 40 pounds; class 2, 40 to 60 pounds; class 3, 60 to 120 pounds, and class 4, 120 pounds to about 200 pounds when they are finished. All foods are calculated in 'food units,' using one pound of grain, such as barley, corn, wheat, etc., as a basis. In roots and other green feed the food units are estimated on their dry matter, as, for example, 8 pounds of mangels, 4 pounds boiled potatoes, 5 pounds of lucerne or 5 pounds sugar beets equal one food unit. In the case of milk 6 pounds and whey 12 pounds are calculated to have a feeding value of one food unit. In other words the feeding value of 1 pound of grain (barley, corn, wheat, shorts, etc.) has the same feeding value as 6 pounds of milk, 8 pounds of mangels, 4 pounds boiled potatoes, 5 pounds of sugar beets or 5 pounds of green lucerne or green vetches.

The diet is varied according to the classes of pigs. In class 1 the ration consists of 30 per cent milk and 70 per cent grain, calculated in food units. In other words, the mixture fed consists of 180 parts $(6 \times 30=180)$ by weight of milk to 70 parts by weight of meal.

In food units class 2 gets 25 per cent milk, 70 per cent grain and 5 per cent roots or green fodder. The mixture fed at this stage consists, therefore, of 150 parts $(6 \times 25=150)$ by weight of milk, 70 parts by weight of grain and 40 parts $(5 \times 8=40)$ by weight of mangels. If lucerne or vetches were fed instead of roots this part of the mixture would be 25 parts by weight of the mixture, and corresponding weights in the case of sugar beets, boiled potatoes, etc. 
Class 3 gets 15 per cent milk, 75 per cent grain and 10 per cent roots, or green fodder. This ration consists of a mixture of 90 parts by weight of milk, 75 parts by weight of grain and 80 parts by weight of mangels, etc.

Class 4 - each pig gets threee quarters of one food unit ( $4 \frac{1}{2}$ lbs.) of milk, one-quarter of one food unit ( $2 \mathrm{lbs}$.) of roots, if mangels, of $1 \frac{1}{2}$ pounds if sugar beets or lucerne, and the remainder in the form of grain.

The food is given in the form of a slop, rather thin while the pigs are young and thicker towards the end. The food is prepared one day ahead. At the station visited in July the grain mixture consisted of about equal parts of barley, corn, oats and shorts. The feeding was done three times daily, and while the appetite was satisfied at each meal the trough was always cleaned up by the time the meal was over. It was evident that the feeding was intelligently done. Young pigs up to 60 pounds of weight get charcoal, and when necessary to regulate the bowels, a little cod liver oil.

\section{GAINS BY AGES.}

The Danish farmer is convinced that the cost of gains increase with the age and weight of pigs. This has been repeatedly proven at the experiment stations. The following table shows the food units required in summer to make one pound of gain in pigs of different weights :-

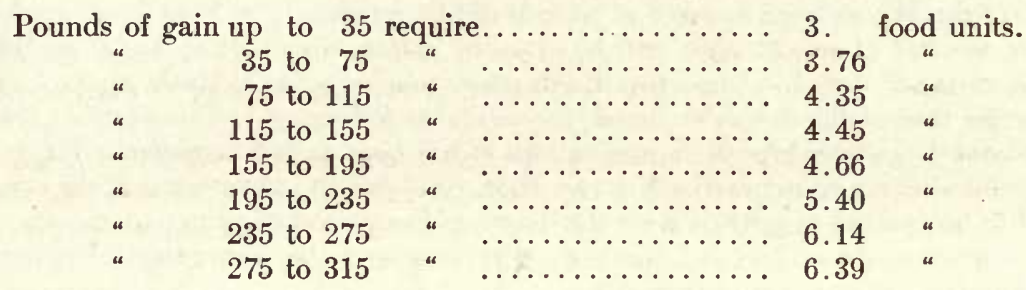

Winter feeding has proved to be a little more expensive, the ratio being as follows :Summer-
4.5 food units.
4.6
4.6 Winter- 3.7 food units.
4.5
5.2

The above figures represent the result of carefully conducted feeding tests during many years. They have been verified so ofter that they are taken as conclusive, not only by the officers of the experiment station and the Department of Agriculture, but by farmers throughout the country. This system of feeding according to the weight of the pigs is believed to give the maximum of profit from the food consumed. This too has the confidence of the feeders throughout the length and breadth of the land. By lectures and the distribution of literature all farmers know these things, and, being educated and thrifty, they do not follow old systems and customs because they are old, but adopt the new because they believe them to be more profitable. The experiment station is believed in; and feeders everywhere are anxious to learn and adopt the methods recommended by these institutions. It must be remembered that those in charge of the station work are not only extremely practical but sufficiently conservative to be sure of the accuracy of their findings before giving them out. Instead of spinning fine theories and endeavouring to work these out, they begin at the other end and consult the pig first and follow the way opened. The result of this is that pig feeding throughout Denmark is extremely uniform. The Commission visited a large number of representative farms and learned by observation that this is the case. All feed milk or whey, and all use green food, while each man uses the particular grain mixture he is able to procure most economically. In some cases home grown barley or oats was being fed, while in others shorts, bean meal or some other foreign food was in use. These are intelligently blended so as to get the most from the ration. Some feed three times daily, others four times, but all use much the same character of ration. Because the highest 
quality of bacon is made from pigs finished on barley, practically all feeders use this grain freely towards the last. Following are details of the conditions and practices found to exist on a number of farms visited:-

Farm 1.-70 acres; grows 15 acres of roots; keeps 28 cows; turns off 100 fat pigs per year; buys $\$ 1,200$ worth of grain for cows and pigs; sells $\$ 3,500$ worth of cream; weans pigs at six weeks; feeds skim milk, shorts, barley meal and green lucerne chopped and mixed into a slop; sells at 180 pounds at 5 months old; in 1908 sold pigs at 13 cents per pound dressed weight and made $\$ 1.50$ profit per pig; in 1909 he hoped to get a profit of $\$ 3.50$ per pig on account of the better price.

Farm 2.-90 acres; milks 15 cows; sells 50 pigs a year; weans at two months; feeds till 5 months old on barley, corn, green feed, shorts, roots and milk; finishes on barley, corn and milk; buys $\$ 250$ worth of feed a year; grows 4 acres of turnips, 11 acres of mangels and 5 of potatoes.

Farm 3.-50 acres; sells 40 pigs a year; weans at 6 weeks old; feeds milk, barley, shorts, roots, and green feed; finishes at 5 months old on corn, barley and milk; pigs from Danish dam and Yorkshire sire.

Farm 4.--80 acres; milks 11 cows; sells 40 to 50 pigs per year; weans at 6 weeks; feeds milk, green feed, shorts and barley meal; finishes at 6 months old on rye, barley and milk.

Farm 5.-120 acres; milks 28 cows; keeps 5 brood sows; sells 90 pigs a year; feeds until 5 months old on milk, roots or green feed and shorts; finishes at 6 months on barley and milk.

Farm 6.-70 acres; keeps 3 Danish sorws; sells 40 to 50 pigs a year; buys $\$ 300$ worth of concentrated food; dry sows thin but thrifty, growing pigs a very thrifty lot; pigs finished on barley and milk.

Farm 7.-110 acres; 30 cows; 14 Danish brood sows; sells 250 fat hogs per year; keeps pigs growing nicely on such cheap food as whey, skim milk, lucerne and shorts; feeds no whey before two. months old; feeds until 4 months old on milk, whey, green feed and chop; finishes on barley, corn and milk with very little green food.

Farm 8.-7 acres; keeps 3 cows; 1 horse; sells 20 pigs a year; buys $\$ 150$ to $\$ 160$ worth of feed per year; every foot of land bearing heavy crop; proprietor enjoying all home comforts.

Farm 9.-110 acres; 30 cows; sells 200 pigs; buys $\$ 700$ worth of feed for pigs and $\$ 700$ worth for cows; was feeding pigs milk, vetches and damaged barley; grows 14 acres of mangels.

At each of the above farms and many more visited, the arrangements were much the same. Almost every piggery has a large feed mixing tank of either cement or wood in which was found a sloppy mixture consisting of milk, chop and cut, green feed. Near by was an ordinary straw cutter through which all green feed is passed. This green feed varied-lucerne, red clover, vetches, peas and oats all being grown for the pigs and cows. The chopped green feed is mixed in with the slop. The tank in many cases was divided so that suitable food could be prepared for pigs of different ages.

Up to within six weeks of farrowing the brood sows are maintained chiefly on kitchen refuse, with some wheat bran, shorts, or crushed oats, a few roots in winter, and green feed in summer. In fact, almost any combination of feed which is economical and will keep the sow in a healthy condition is used. During the last six weeks of pregnacy the regular ration is increased somewhat and some heavier food given. This gets the sow in fairly good flesh by the time she has to suckle the litter. For a few days previous to farrowing the bran is increased and the other feed decreased. The ration is fed in the form of a thin slop. The feed is the same for about three days after farrowing. Then the sow is fed very liberally on grain and dairy by-products. In cold weather many farmers warm the feed. The pigs are always taught to eat by the time they are three weeks old.

The thrifty condition of the pigs all along the way was a matter of general surprise. Dry sows, usually thin, were full of vigour. Litters were extremely even and well developed, while older pigs were invariably large for their age This is shown in the above notes $10489-5 \frac{1}{2}$ 
showing the ages at which many pigs are finished. Although the pigs are housed constantly very rarely was seen a cripled animal. While every feeder follows a system, each one varies the feeding from time to time according to his judgment.

\section{Housing.}

The comforts of Danish pigs are well looked after. Except at some of the breeding stations all pigs are constantly housed. Proprietors of breeding stations being especially anxious for the vitality of their stock, provide outside runs, more especially for brood sows and stock boars. The object of the pork raiser is rapid gains, and this he believes he secures by constant housing. Apart from this every available foot of land is utilized for crop growing, so that no stock is allowed to run about. The cattle, horses, and frequently the sheep, when grazing are tethered and moved once or twice a day.

The hog pen is a part of the general farm building, and is practically the same in construction as the horse and cow stable. The farm-steading consists of a continuous building occupying four sides of a courtyard, 40 to 60 feet across. 'The dwelling is situated parallel with the horse stable and feed barn, while the cow stable and the piggery face each other on the remaining sides of the courtyard. The court is entered by a drive-way, in some cases situated between the end of the piggery and the corner of the dwelling, in others through the centre of one side. The courtyard is macadamized. The buildings, usually one story high, are of cement or brick. The roof is either tiling or straw thatch. The pen floors, feeding troughs, and frequently the partitions, are of cement concrete. Wooden floored sleeping pens were seen in a few cases and one feeder used elevated sleeping quarters for the pigs. Most piggeries have a single row of pens with passage on one side. The windows were usually small, but no dark pens were seen. The floors are kept dry by a grating to take away the liquid manure to a tank. As in most old countries the farm buildings in Denmark are constructed to endure; even the ceilings in a number of stables were built of cement. The Commission had no opportunity of judging of the suitability of the piggeries for winter, but supposed they would be damp. Plenty of straw is grown and, no doubt, by the liberal use of this the resourceful Dane makes his pigs comfortable at all seasons of the year.

\section{Co-operative Feed Buying.}

The Danish farmer is a very extensive purchaser of feed for stock, and to secure this as cheaply as possible he has applied to a remarkable degree the principle of co-operation. An organization known as "The Co-operative Association for Purchasing Food Stuffs" has a membership of 30,000 . The association is divided into small local societies throughout the country. In addition to nine large distributing warehouses located at convenient shipping points, there are a large number of smaller local stations for the convenience of members. The following translation from the report of the association for 1908 explains the objects of the organization and its general system of conduct:-

"The object of the co-operative association is to obtain for its members cheap and good food stuffs, and to guard against the possibility of rings being created in the mercantile world.

"The shareholders bind themselves in writing, that for a period of five years they will take their food stuffs, with the exception of grain produced at home, through the association.

"Any member who agrees to carry out the above mentioned obligation is considered a shareholder of the association.

"Other societies who take the same obligation may be accepted as shareholders when the guarantees furnished are considered satisfactory.

"The association holds general meetings when it is considered necessary by the committee, or when one-fifth of the delegates demand it.

"The management have a head office and appoint a competent manager, also a treasurer, both to furnish the necessary guarantees. 


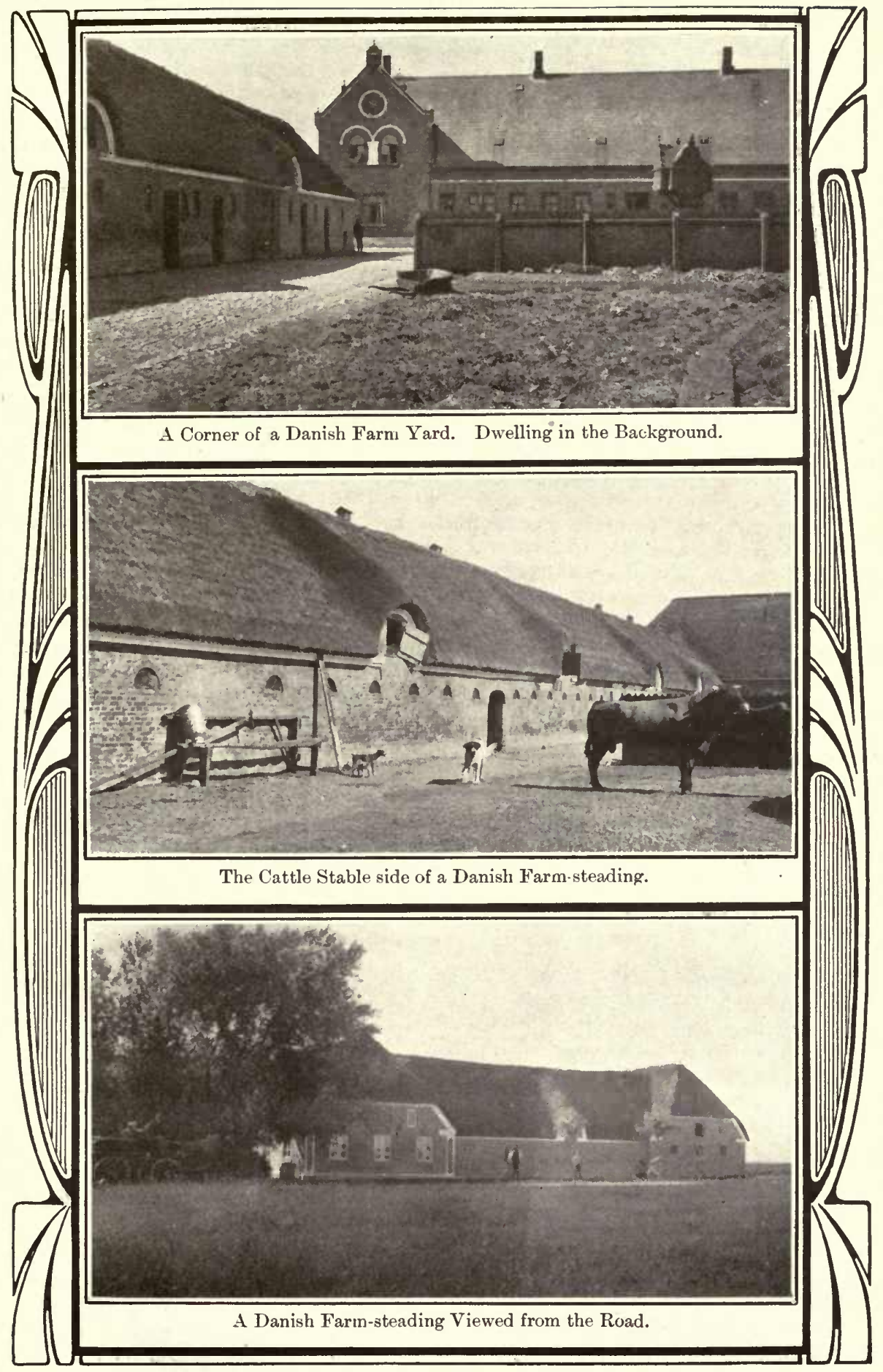



"The manager has the power to buy food stuffs and to sell grain, look after the transmission of food stuffs, appoint the clerks and present the annual report. He is also responsible that the goods are insured against fire and disaster at sea.

"Orders are submitted through the presidents of the local associations.

"Goods are paid for by the associations inside of a month.

"If any shareholder purchases goods anywhere else than through, the association, he is liable to a fine of 50 cents per 100 pounds.

"Should the head office on account of bad weather, etc., be unable to supply shareholders with goods ordered they are at liberty to obtain what they need from other sources.

"Any surplus is divided among the shareholders according to the purchases of food stuffs.

"Each year 25 per cent of the surplus is added to a reserve fund.

"Should any shareholder desire to sell grain through the head office, it is the duty of the manager to arrange such a sale."

This association is far reaching in many ways. It deals in all manner of foods suited for farm animals, purchasing them in the most favourable markets throughout the world. It goes to Mexico for cotton seed cake and to Manchuria for soja bean cake. It secures large quantities of barley from Russia, and when corn is cheap enough ship loads are bought in the United States. Oil cake stands at the head of its purchases, of which considerably more than 100,000,000 pounds were purchased during the year ending May 31st, 1909. Sunflower cake, used chiefly for cow feed, is heavily purchased, over $60,000,000$ pounds being imported during the year; then comes corn, barley, bran, hemp seed cake, etc., in the order named. By a careful system of inspection and analysis all foods purchased are guaranteed to be of good quality. The transactions of the association for the year indicated involved no less than $308,000,000$ pounds, costing about $\$ 4,750,000$. The foods are paid for by the members at the prevailing local market price quoted by regular feed merchants. At the end of the year the profits belonging to each member are remitted. 'The net profits for the year 1908-09 amounted to about $\$ 200,000$. It will therefore be seen that by skillfully managed co-operation the Danish farmer gets his feeds at a comparatively low price. It is this kind of intelligent thrift that has placed the Danish bacon producer at the head of his class.

The following table gives the market prices in dollars per ton of 2,000 pounds of barley, corn and middlings in Denmark, Canada (Toronto) and England, during July, 1909 :-

\begin{tabular}{|c|c|c|c|}
\hline & Denmark. & Canada. & England. \\
\hline Bar & $\$ 2650$ & $\$ 2665$ & $\$ 2766$ \\
\hline Cor & . . 3146 & 2900 & 3160 \\
\hline Middling & . $\quad 3338$ & 2600 & 2800 \\
\hline
\end{tabular}

Note.-The middlings quoted for Denmark consist of a low grade flour-a heavier food than middlings quoted in Canada and England. This accounts for the great difference in price between Denmark and the other countries. The values of foods quoted for Denmark, Canada and England are taken from published market reports as they appeared in reliable newspapers of July, 1909.' Danish farmers who purchase feed through the cooperative feed buying associations, secure a rebate of the profits at the end of the year as explained above.

\section{Co-operative Bacon Packing.}

Most Canadians to any extent interested in bacon production are more or less familiar with the Danish System of Co-operative curing. The subject has been discussed and written about a great deal during the past few years. The Commission visited a number of the Danish co-operative curing factories and learned as much as possible of the system on which they are conducted. 
The co-operative curing of bacon in Denmark dates back to 1887 when the farmers found their live pigs shut out of Germany which had been the chief market. There were at the time a number of private curing factories, but pig raisers felt they were not getting full value for their stock and seeing the success that had already attended co-operative butter making it required only the initiative of a few strong men to set swine slaughtering, curing and marketing on a profitable basis. Established on a sound basis and governed by workable regulations the first factory succeeded and others were started until inside of three years ten such organizations were in operation. This number year by year was added to until it has reached 36 besides 24 private packing houses scattered over the little country so close indeed in many cases that 90 per cent of the hogs killed are brought in by waggon. For a number of years it is claimed proprietory owners sought by various means to discourage the co-operative movement, but the foresight, persistence and stability of the Danish farmer prevented even a halt in its progress until it soon was able to dominate the situation. The private concerns are gradually being reduced in favour of the others, and it is only because of their generous policy that they can get hogs. They not only have to pay a slightly higher price than the quotations of the co-operative associations but they have to bring their hogs longer distances. Whereas a co-operative factory seldom has to bring more than 10 per cent of its stock by rail a proprietary factory frequently gets 50 per cent by train and those from districts in which the farmers have not yet joined a co-operative association. These associations have a foot hold in practically all districts where hogs are reared in considerable numbers, the total membership being about 100,000 .

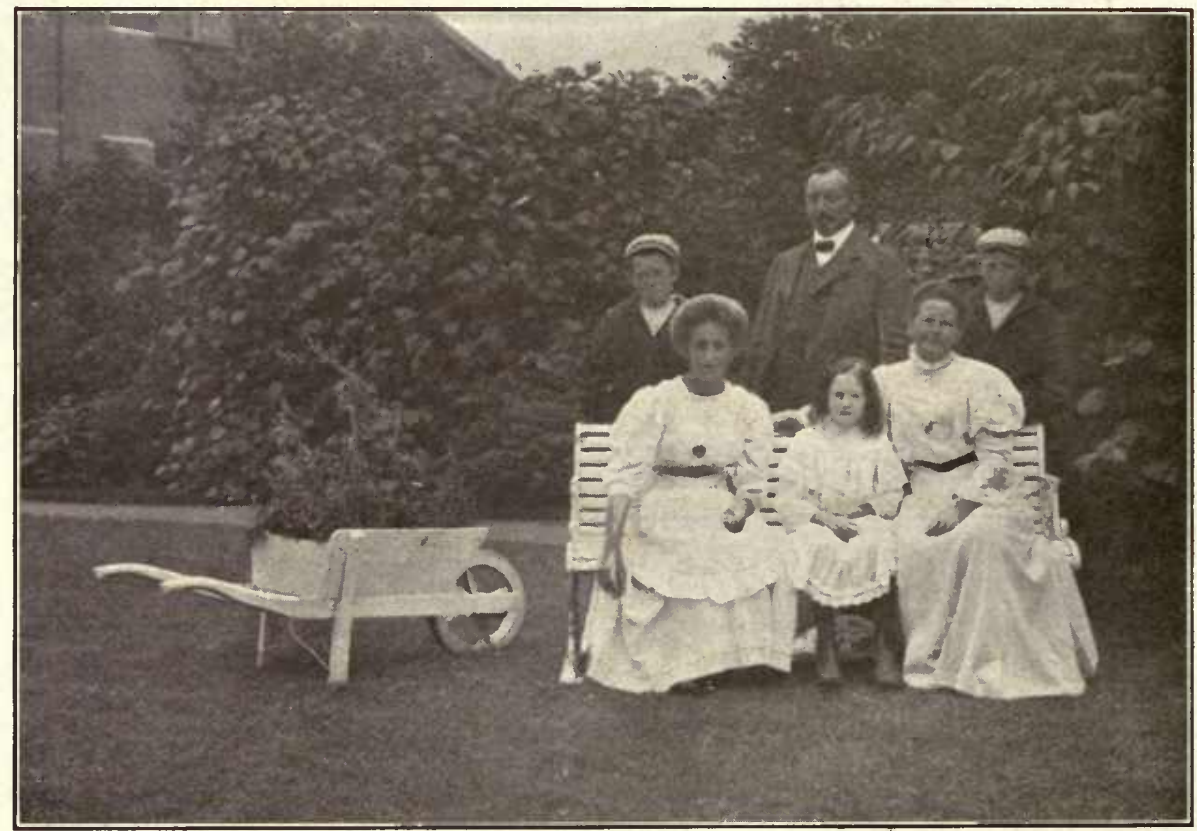

Manager F. L. Sieck, of a Danish Co-operative Packing House, with his family.

Two main factors have been responsible for the success of co-operative packing associations from the first. No capital had to be supplied by the shareholders and each pledged his entire output of fat hogs to the co-operative association.

On the joint guarantees of shareholders the banks provide the necessary money for the erection and equipment of the factory and working capital. The working fund is increased in the beginning by holding back a small part of the value of the hogs slaughtered. When this has reached an amount sufficient to carry on the work the capital sum provided by the 


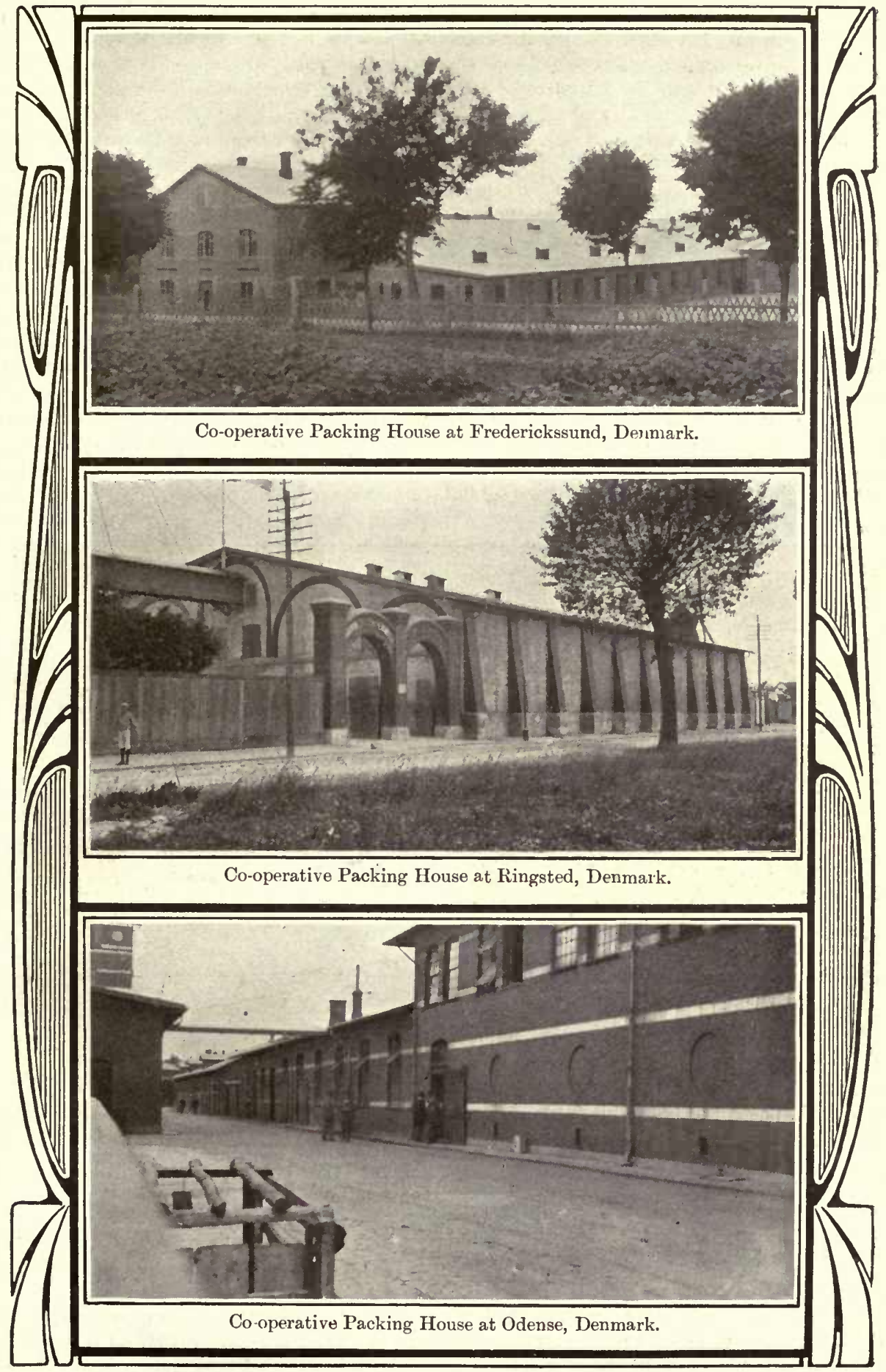



bank is reduced year by year. As a rule the principal is paid off at a rate to clear the whole debt in twenty to thirty years. The following is a usual form of guarantee:-

We the undersigned hereby pledge ourselves to deliver to the Co-operative Bacon Factory which it is proposed to establish, all the pigs of weights between 150 and $200 \mathrm{lbs}$. which we may produce for sale. Such pigs will be delivered on conditions decided by the shareholders of the Society, and that we shall receive such amount in payment of such delivered swine as may be realized for them by the factory less preliminary expenses incurred in the organization of the Society and the annual instalments on loan for building and plant payable during a period of about 25 years together with current working expenses.

The guarantee is graduated according to the number of acres owned by each member respectively. Ownership of 25 acres or less is sufficient for a guarantee of about $\$ 14$; between 25 and 250 acres, $\$ 28$; and for larger amounts $\$ 28$ for each 250 acres. The guarantee of one member in no case exceeds $\$ 135$. It is a fundamental principle that each guarantor is a partner in the ownership of the whole property of the factory in proportion to the amount of his respective guarantee. The penalty for violation of the agreement to deliver all marketable pigs to the co-operative factory is $\$ 2.70$ per pig sold to any other concern or person. The further penalty of expulsion from the Association may also be exacted.

Shareholders who live within 6 miles of the factory as a rule deliver their pigs free, but those living at a greater distance deliver to the nearest railway station, and the association pays the freight from there to the factory. In some associations a bonus of about 7 cents per hog is granted the shareholders who deliver their own pigs. The packing plant agrees to accept every sound hog delivered. The pigs when delivered are unloaded into a small car and a metal tag is put into the ear of each for identification. If the owner so desires the pigs may be weighed alive. Immediately after being dressed they are weighed and classified. An advance covering a portion of the value, based on the current quotations and the class to which the carcass belongs, is made at once. About one-quarter of a cent per pound is withheld until the end of the year, when the final premium is paid on the basis of weight of pork delivered during the year.

\section{Fixing the Price.}

In each province or district there is a committee to fix the prices for the factories in that province or district. Quotations are fixed on Saturday morning for the following week. The committee charged with this learns the views of the several committees attached to individual co-operative factories, and sets the price according to the average of the recommedations of the several local committees. That is to say, if five committees recommend 45 ore per pound while five others place the figure at 46 ore per pound for grade No. 1 , the general committee sets it at $45 \frac{1}{2}$. To guard the interests of all concerned an arbitrator is appointed to decide cases in dispute.

A local committee to arrange quotations consists of three, the president, a well known farmer who is not a director of the association, and the manager of a factory. The manager lays before the others the latest telegrams and information in regard to the state of the British bacon market and the results of the consignments shipped during the week. After providing for a profit of $\$ 1,25$ to $\$ 1.75$ per hog and a quarter of a cent for working expenses, the com mittee decides upon its quotation. It was pointed out to the Commission that it is not always possible to allow for a profit per hog as large as stated above. At times of low values and dropping prices current quotations are held up. This condition occurred during 4 or 5 months early in 1908, when quotations were maintained as high as possible to satisfy the producers, and thus keep up the weekly supply. The return of good prices later enabled the association to make their entire profits for the year during the last 6 or 7 months. Care has always to be taken to see that the quotations during the year are on the safe side. It is usually sufficiently low to allow of a final dividend of from three-quarters to one cent per pound for all deliveries during the year. Considerable competition exists between co-operative associations as to which shall pay the highest final dividends.

The Commission was advised that no steps are taken by the association to discourage heavy deliveries during any particular season of the year, as, for instance, the fall when other countries have heavy runs. The farmers have learned the wisdom of even distribu- 
tion throughout the year. Apart from this the farmers are guided in the number of pigs fed on the production of milk. Since this is fairly constant throughout the year, it follows that the pig stock is, as a rule, about the same from month to month and from season to season.

The affairs of each association are managed by a board of directors elected by the members. The directors choose a manager and secretary. The manager, subject to the supervision of an auditing committee, has complete control of the business-buying the hogs, hiring the help, curing and selling the bacon. He is a very carefully selected man and gets a good salary. The managers met by the Commission were very brilliant, hard working men, keenly alive to all the details of the work. Some of them at least go to England once or oftener each year to study the market and endeavour to extend their trade.

Necessarily the co-operative factories in Denmark vary in size and capacity. Seven or eight factories have capacities for handling about 20,000 hogs per year. These are the smaller plants. One of such, situated at Hasloe, gets its pigs from a radius of about 15 miles. About 18,000 are received by wagon and 2,000 by rail. A large factory was visited at Frederikssund having a capacity of 50,000, or 1,000 per week. Others again run higher. The value of such a factory fully equipped with modern machinery is from $\$ 60,000$ to $\$ 70,000$ and requires a working capital of $\$ 50,000$. The association owning this plant has a membership of 3,000 . The capital $(\$ 110,000)$ was raised in a local savings bank at a rate of interest of 4 per cent, the whole to be paid back out of the yearly dividends in from 20 to 30 years. In accordance with the general system over the country the shareholders guarantee the bank for the loan to the factory according to the average supply of pigs.

The cost of handling pigs is larger in the smaller factories. According to the experience of the Danish Co-operative Slaughteries during the past ten years the expenses as regards interest, management, labour, etc., was as follows:-

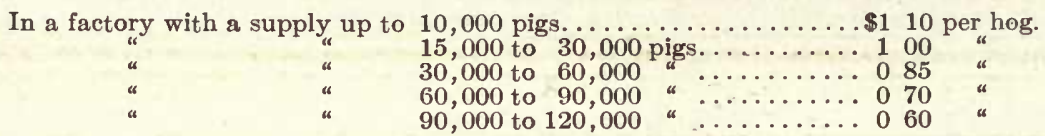

The small and medium sized factories handling up to 60,000 pigs have less expense than the larger ones on railway freight, and also lose less through shrinkage from live to dead weight. These factories are also able to command higher prices for their offal articles, as a limited quantity of these can always be sold locally. On the other hand, larger factories have often to sacrifice offal on account of over-supply. The co-operative associations conduct retail local stores in which all classes of their products are sold. These provide a profitable market in many by-products that cannot be shipped with advantage.

Following are the values of offal articles, such as heads, feet, lard, entrails, bones, tongues, etc., in factories of different sizes:-

$$
\begin{aligned}
& \text { Factories } 10,000 \text { to } 20,000 \ldots \ldots \ldots \ldots \ldots \ldots \ldots \ldots \ldots \ldots 200 \text { to } \$ 225 \text { per hog. }
\end{aligned}
$$

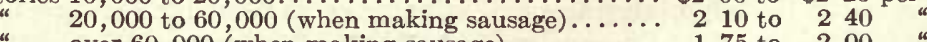

$$
\begin{aligned}
& \text { over } 60,000 \text { (when making sausage)........... } 175 \text { to } 200 \text { " }
\end{aligned}
$$

The factories near large cities, such as Copenhagen, generally obtain from twenty-five cents to fifty cents more per hog for their offal than the factories farther away. Larger factories have an advantage over smaller ones in being able to secure a broader recognition for their particular brand of bacon, lard and other articles. Smaller ones find it difficult to get recognition as they have not sufficient of the different selections to make an impression on the market. These have often to sell their more or less irregular shipments in the open market, and, in many cases, unbranded. The medium and larger factories when well managed secure a reputation for the products bearing their brands, which gives them an advantage of from twenty-five to fifty cents per cwit. more than the smaller factories secure. If they then do business direct, principally with retailers, they command fully twenty-five cents more per cwt. than when the goods are sold through agents. So far comparatively few factories in Denmark, sell direct to the British retail trader. The goods are shipped f. o. b. at the buyer's risk. 


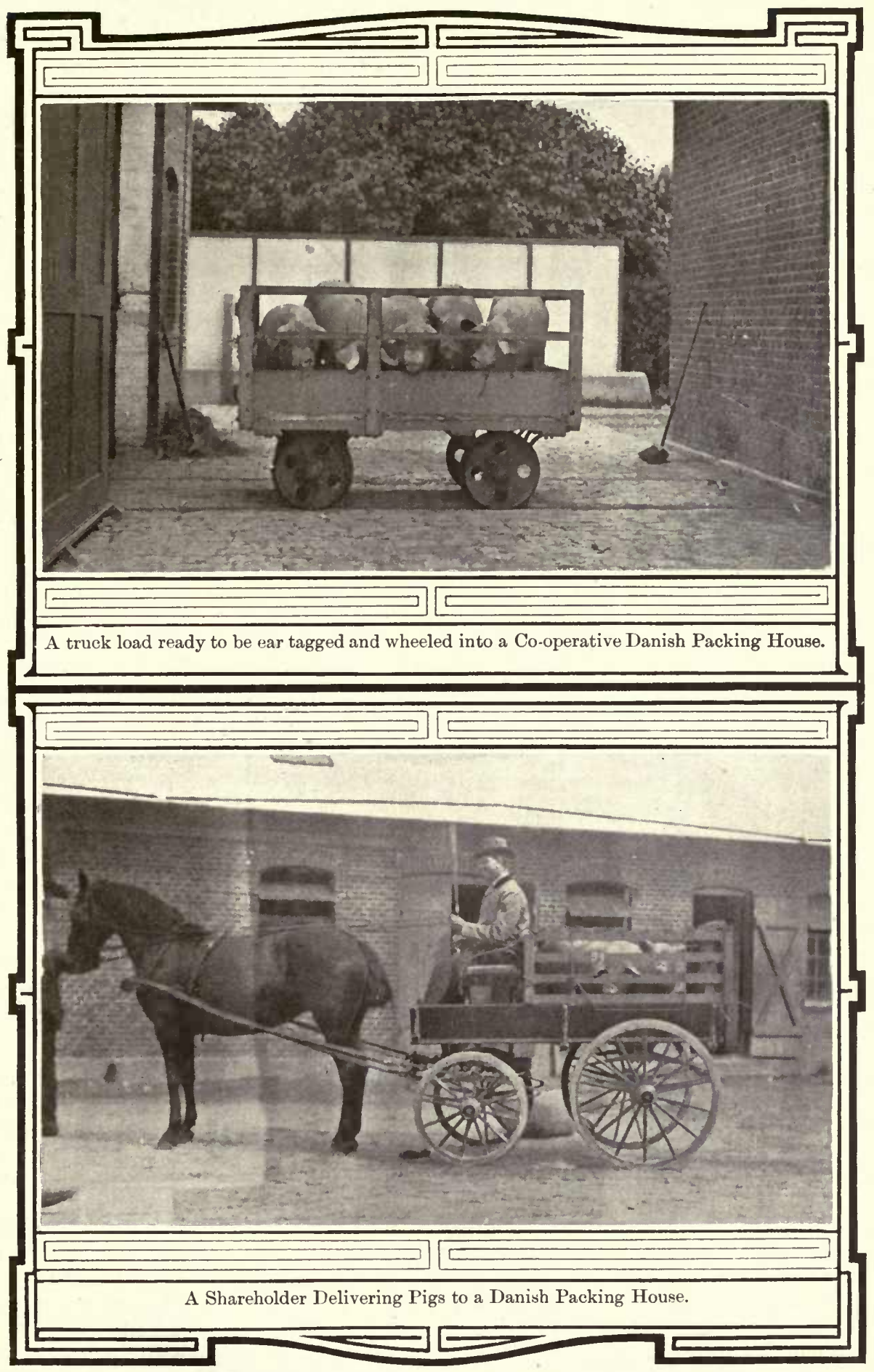


It may be mentioned that the question of overcoming the present eommission system in vogue in the English market, whereby goods are sold on a three per cent basis, is receiving the attention of the Danish co-operative associations, and, it is hoped, sooner or later to effect an arrangement to greatly reduce this commission.

The general yearly dividend paid by the Danish co-operative factories is from $\$ 1.75$ to $\$ 2$ a hog; but it was expected to reach about $\$ 235$ per hog for the year 1909-10.

\section{THE GROWTH OF THE INDUSTRY.}

The following table prepared by the Secretary of the Central Association of Cooperative factories at Copenhagen shows the growth of the bacon curing industry since the opening of the first co-operative factory in 1888:-

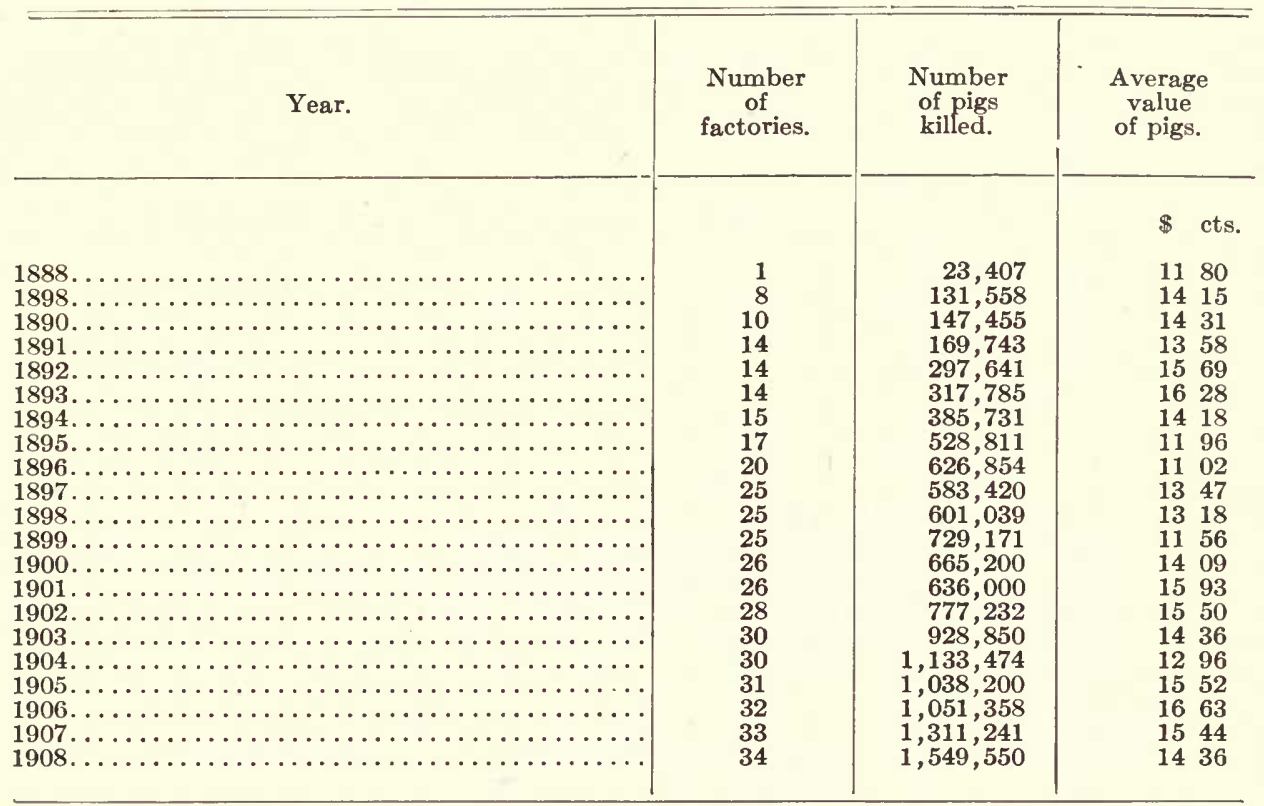

PRICES PAID TO FARMERS FOR BACON PIGS IN CANADA AND DENMARK.

The following table shows the prices paid per 100 pounds live weight for bacon pigs of first quality to the shareholders of Danish Co-operative factories, and to farmers in the province of Ontario, month by month for the period commencing January, 1903 and ending July, 1909. The Canadian prices are those paid at country points, F. O. B., which would correspond with those paid at the Danish factories. Since Danish pigs are paid for by dressed weight the prices given represent live weight estimated on a shrinkage of 25 per cent from live to dressed weight. According to Danish officials this is as nearly as possible the actual loss of weight that takes place in the process of killing and dressing. The comparative prices of Canadian and Danish bacon on the British market are shown on page 55 . 


\begin{tabular}{|c|c|c|c|c|c|c|c|c|c|c|c|c|c|c|c|}
\hline & ஓे & $\begin{array}{l}\dot{m} \\
\text { d } \\
\infty\end{array}$ & & & & $\begin{array}{l}\infty \\
\infty \\
1\end{array}$ & $\begin{array}{l}18 \\
\infty \\
\infty\end{array}$ & $\begin{array}{l}10 \\
0 \\
\infty\end{array}$ & $\begin{array}{l}\infty \\
\infty\end{array}$ & & & & & & \\
\hline & $\stackrel{\infty}{\stackrel{\infty}{\circ}}$ & $\begin{array}{l}\dot{x} \\
\dot{0} \\
\infty\end{array}$ & $\begin{array}{l}8 \\
1\end{array}$ & $\begin{array}{l}H \\
0\end{array}$ & $\begin{array}{l}\text { กิ } \\
0\end{array}$ & $\begin{array}{l}\text { ஜ } \\
0\end{array}$ & $\begin{array}{l}\text { J } \\
0\end{array}$ & $\begin{array}{l}8 \\
1\end{array}$ & E & $\begin{array}{l}100 \\
12\end{array}$ & $\begin{array}{l}\text { 䓟 } \\
\text { in }\end{array}$ & $\stackrel{\infty}{\stackrel{\infty}{N}}$ & $\begin{array}{l}\vec{\infty} \\
0\end{array}$ & $\begin{array}{l}\vec{\infty} \\
0\end{array}$ & ळ \\
\hline & 今. & $\begin{array}{l}\text { 兽 } \\
\infty\end{array}$ & $\begin{array}{l}10 \\
12 \\
12\end{array}$ & $\begin{array}{l}10 \\
10 \\
1\end{array}$ & $\begin{array}{l}\text { 只 } \\
12 \\
1\end{array}$ & $\begin{array}{l}\text { rి } \\
\text { r }\end{array}$ & $\begin{array}{l}\text { Sू } \\
\text { న }\end{array}$ & $\begin{array}{l}\text { ? } \\
\text { r }\end{array}$ & 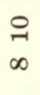 & $\begin{array}{l}\infty \\
\text { N } \\
\infty\end{array}$ & ヘ & 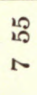 & $\begin{array}{l}8 \\
1\end{array}$ & $\begin{array}{l}8 \\
1\end{array}$ & $\overline{6}$ \\
\hline 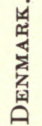 & \& & $\begin{array}{l}\text { 密 } \\
\text { की }\end{array}$ & $\underset{\infty}{\stackrel{一}{\infty}}$ & $\begin{array}{l}\mathscr{f} \\
\infty\end{array}$ & $\begin{array}{l}J \\
\infty \\
\infty\end{array}$ & $\begin{array}{l}\text { J゙ } \\
\infty\end{array}$ & $\begin{array}{l}\text { N } \\
\text { N- }\end{array}$ & $\stackrel{\circ}{\stackrel{一}{\infty}}$ & $\begin{array}{l}\text { 市 } \\
\infty\end{array}$ & $\begin{array}{l}\infty \\
\infty \\
\infty\end{array}$ & $\stackrel{\circ}{\stackrel{-}{\infty}}$ & i & $\begin{array}{l}\infty \\
i \\
i\end{array}$ & $\begin{array}{l}8 \\
1\end{array}$ & $\stackrel{\infty}{\infty}$ \\
\hline & \&̊요 & $\begin{array}{l}\dot{0} \\
\stackrel{0}{0} \\
\infty\end{array}$ & $\begin{array}{l}J \\
0 \\
0\end{array}$ & $\begin{array}{l}8 \\
1\end{array}$ & $\begin{array}{l}\stackrel{\Gamma}{\circ} \\
\sim\end{array}$ & $\begin{array}{l}\text { 跑 } \\
\text { 1 }\end{array}$ & $\begin{array}{l}\stackrel{2}{\sim} \\
\sim\end{array}$ & 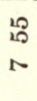 & $\begin{array}{l}\text { ๙ } \\
\text { N }\end{array}$ & $\begin{array}{l}\text { ㅇ } \\
\text { م }\end{array}$ & $\begin{array}{l}\text { ల్ } \\
\text { r }\end{array}$ & $\begin{array}{l}\mathscr{m} \\
i\end{array}$ & $\begin{array}{l}\text { 용 } \\
12\end{array}$ & $\stackrel{\infty}{\sim}$ & $\begin{array}{l}7 \\
1\end{array}$ \\
\hline & ङ્ఠ & $\begin{array}{l}\stackrel{s}{3} \\
\infty \\
\infty\end{array}$ & $\begin{array}{l}\text { \& } \\
0\end{array}$ & $\begin{array}{l}\stackrel{\circ}{*} \\
0\end{array}$ & $\begin{array}{l}\text { \& } \\
0\end{array}$ & $\begin{array}{l}8 \\
10\end{array}$ & $\begin{array}{l}J 1 \\
0\end{array}$ & $\begin{array}{l}\infty \\
0 \\
0\end{array}$ & $\begin{array}{l}\text { N } \\
0\end{array}$ & $\begin{array}{l}\varnothing 0 \\
0\end{array}$ & $\begin{array}{l}\infty \\
0 \\
0\end{array}$ & $\begin{array}{l}\infty \\
0 \\
0\end{array}$ & $\begin{array}{l}\infty \\
0 \\
0\end{array}$ & $\begin{array}{l}8 \\
10\end{array}$ & $\stackrel{9}{0}$ \\
\hline & $\stackrel{\leftrightarrow}{\stackrel{\leftrightarrow}{ٌ}}$ & $\begin{array}{l}\stackrel{\dot{0}}{\mathrm{~d}} \\
\dot{\theta}\end{array}$ & $\begin{array}{l}8 \\
1\end{array}$ & $\begin{array}{l}\mathscr{0} \\
0\end{array}$ & $\begin{array}{l}8 \\
1-\end{array}$ & $\begin{array}{l}\vec{\infty} \\
0\end{array}$ & $\stackrel{\infty}{\sim}$ & $\stackrel{\infty}{\sim}$ & $\begin{array}{l}\text { లో } \\
\text { N }\end{array}$ & 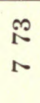 & $\begin{array}{l}\text { \% } \\
\text { r. }\end{array}$ & $\begin{array}{l}8 \\
1\end{array}$ & $\begin{array}{l}\mathscr{8} \\
0\end{array}$ & $\begin{array}{l}\text { N } \\
0\end{array}$ & $\begin{array}{l}8 \\
1\end{array}$ \\
\hline \multirow{7}{*}{ 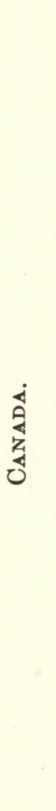 } & ஓें & $\begin{array}{l}\dot{0} \\
\dot{0} \\
\infty\end{array}$ & $\begin{array}{l}+1 \\
0\end{array}$ & $\begin{array}{l}\text { ณ } \\
\text { : }\end{array}$ & $\begin{array}{l}\infty \\
\infty\end{array}$ & $\begin{array}{l}8 \\
1\end{array}$ & $\begin{array}{l}\text { J } \\
\text { r }\end{array}$ & $\begin{array}{l}\text { J } \\
\text { N }\end{array}$ & $\begin{array}{l}\tilde{\sigma} \\
\mathrm{N}\end{array}$ & $:$ & & : & & & \\
\hline & 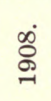 & $\begin{array}{l}\dot{x} \\
\text { Ud } \\
\infty\end{array}$ & $\begin{array}{l}\text { 足 } \\
\text { in }\end{array}$ & $\begin{array}{l}1 \\
\text { is }\end{array}$ & $\begin{array}{l}28 \\
8 \\
+1\end{array}$ & $\begin{array}{l}8 \\
0\end{array}$ & $\begin{array}{l}\text { J' } \\
\text { is }\end{array}$ & $\begin{array}{l}18 \\
10 \\
10\end{array}$ & भิ & $\begin{array}{l}108 \\
0 \\
0\end{array}$ & $\begin{array}{l}\text { J } \\
0\end{array}$ & $\vdots$ & $\begin{array}{l}\infty \\
\infty \\
10\end{array}$ & $\begin{array}{l}8 \\
10\end{array}$ & $\begin{array}{l}8 \\
10\end{array}$ \\
\hline & 용 & $\begin{array}{l}\dot{D} \\
\dot{0} \\
\infty\end{array}$ & $\stackrel{\circ}{\circ}$ & $\begin{array}{l}\mathscr{⿰} \\
\wp \\
0\end{array}$ & $\begin{array}{l}\stackrel{0}{1} \\
0\end{array}$ & $\begin{array}{l}\text { 아 } \\
0\end{array}$ & $\begin{array}{l}\text { g } \\
0\end{array}$ & $\begin{array}{l}0 \\
0\end{array}$ & $\begin{array}{l}8 \\
0\end{array}$ & $\begin{array}{l}8 \\
0\end{array}$ & $\begin{array}{l}18 \\
0 \\
0\end{array}$ & $\begin{array}{l}18 \\
0\end{array}$ & $\begin{array}{l}-1 \\
\infty\end{array}$ & $\begin{array}{l}\text { ల్ } \\
10\end{array}$ & $\begin{array}{l}\text { के } \\
0\end{array}$ \\
\hline & : & $\begin{array}{l}\stackrel{0}{0} \\
\Leftrightarrow\end{array}$ & $\overrightarrow{0}$ & $\begin{array}{l}20 \\
0\end{array}$ & $\begin{array}{l}\stackrel{1}{0} \\
0\end{array}$ & $\begin{array}{l}\text { J } \\
\text { N }\end{array}$ & $\begin{array}{l}8 \\
1\end{array}$ & $\begin{array}{l}\text { 尺े } \\
\text { N }\end{array}$ & $\stackrel{R}{N}$ & $\begin{array}{l}\vec{N} \\
\text { N }\end{array}$ & $\overrightarrow{0}$ & $\begin{array}{l}\text { P } \\
0\end{array}$ & $\begin{array}{l}\text { R } \\
\text { is }\end{array}$ & $\stackrel{\Re}{0}$ & $\begin{array}{l}\infty \\
0 \\
0\end{array}$ \\
\hline & 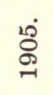 & 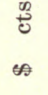 & $\begin{array}{l}\stackrel{2}{2} \\
4\end{array}$ & $\begin{array}{l}\stackrel{\infty}{N} \\
10\end{array}$ & $\begin{array}{l}\hat{0} \\
\text { is }\end{array}$ & $=$ & $\begin{array}{l}\triangleright \\
0 \\
0\end{array}$ & $\begin{array}{l}\text { if } \\
\text { 1 }\end{array}$ & $\begin{array}{l}\overrightarrow{0} \\
0\end{array}$ & $\begin{array}{l}10 \\
0\end{array}$ & $\begin{array}{l}\text { กิ } \\
0\end{array}$ & $\begin{array}{l}8 \\
0\end{array}$ & $\begin{array}{l}\text { 군 } \\
20\end{array}$ & $\begin{array}{l}8 \\
0\end{array}$ & $\begin{array}{l}8 \\
0\end{array}$ \\
\hline & $\begin{array}{l}\text { ர் } \\
\stackrel{-}{-}\end{array}$ &  & $\begin{array}{l}\text { 尺 } \\
\infty\end{array}$ & $\begin{array}{l}10 \\
1 \\
4\end{array}$ & $\begin{array}{l}10 \\
\infty \\
+1\end{array}$ & $\begin{array}{l}28 \\
\infty \\
+1\end{array}$ & $\begin{array}{l}8 \\
+4\end{array}$ & $\begin{array}{l}8 \\
10\end{array}$ & $\begin{array}{l}\stackrel{7}{10} \\
\text { (1) }\end{array}$ & $\begin{array}{l}\text { 군 } \\
20\end{array}$ & $\frac{10}{10}$ & $\begin{array}{l}8 \\
10\end{array}$ & $\begin{array}{l}\stackrel{2}{2} \\
+4\end{array}$ & $\begin{array}{l}80 \\
+1\end{array}$ & $\begin{array}{l}\infty \\
\stackrel{\circ}{+}\end{array}$ \\
\hline & ஜٌ & $\begin{array}{l}\dot{s} \\
0 \\
0\end{array}$ & $\begin{array}{l}\stackrel{20}{2} \\
10\end{array}$ & $\begin{array}{l}10 \\
10\end{array}$ & $\begin{array}{l}\text { 10 } \\
0 \\
0\end{array}$ & $\begin{array}{l}100 \\
\text { m } \\
0\end{array}$ & $\begin{array}{l}\text { Na } \\
0\end{array}$ & $\begin{array}{l}8 \\
\text { is }\end{array}$ & $\begin{array}{l}8 \\
10\end{array}$ & $\begin{array}{l}20 \\
20\end{array}$ & $\begin{array}{l}8 \\
0\end{array}$ & $\begin{array}{l}8 \\
\text { in }\end{array}$ & $\begin{array}{l}\text { P } \\
10\end{array}$ & $\begin{array}{l}8 \\
10\end{array}$ & $\begin{array}{l}\vec{\infty} \\
10\end{array}$ \\
\hline & & & 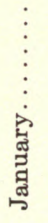 & 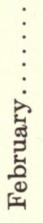 & $\begin{array}{l}\text { jృ } \\
\text { ङूँ }\end{array}$ & 芶 &  & 官 & $\frac{3}{3}$ & 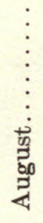 & 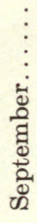 & 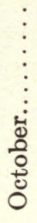 & 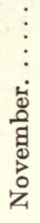 &  & 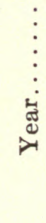 \\
\hline
\end{tabular}


TRANSACTIONS OF ONE FACTORY FOR TEN YEARS.

As an example of the success of the Co-operative system as applied to pig curing and marketing the following table kindly prepared by the manager, F. L. Sieck, is given showing the number of pigs killed in the factory at Frederickssund, the average prices paid including dividends paid to members at the end of each year:-

\begin{tabular}{|c|c|c|c|c|}
\hline$\cdot$ & Year. & $\begin{array}{l}\text { Number of } \\
\text { pigs received } \\
\text { and killed. }\end{array}$ & $\begin{array}{c}\text { Average } \\
\text { prices per lb. } \\
\text { paid, } \\
\text { including } \\
\text { dividends. }\end{array}$ & $\begin{array}{c}\text { The } \\
\text { yearly dividend. }\end{array}$ \\
\hline & & & Cents. & c. \\
\hline $\begin{array}{l}1899 . \\
1900 . \\
1901 . \\
1902 . \\
1903 . \\
1904 . \\
1905 . \\
1906 . \\
1907 . \\
1908 .\end{array}$ & 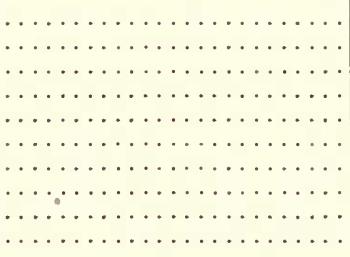 & $\begin{array}{l}27,926 \\
23,417 \\
22,095 \\
26,971 \\
33,832 \\
41,698 \\
48,447 \\
44,372 \\
49,868 \\
57,305\end{array}$ & $\begin{array}{l}8 \\
9 \frac{3}{4} \\
11 \\
11 \\
10 \frac{1}{2} \\
9 \frac{1}{4} \\
10 \frac{3}{3} \\
11 \frac{3}{4} \\
11 \\
10 \frac{1}{2}\end{array}$ & 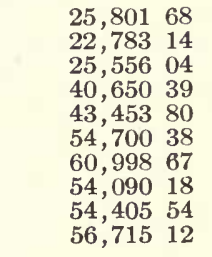 \\
\hline
\end{tabular}

In the bacon curing industry there is a powerful organization cosisting of a co-operation of co-operative societies. It consists of representatives from all of the committees of cooperative slaughteries, embracing all the managers. The central office of the association is at Copenhagen. Its principal duty is to diffuse immediately the latest intelligence regarding the bacon industry among the various branches of the association. This office is furnished from week to week with complete returns of the business transacted at each co-operative factory, including cost of production, and the actual market returns of bacon sold. This information is embraced in a circular which is sent out to all factories enabling them to know how each is succeeding in comparison with other factories. This organization has proved a strong incentive to improved methods and has therefore done much for the industry as a whole.

METHODS OF CURING.

Two methods of curing obtain in Denmark. The usual one is practically the same as is in vogue in Canadian factories, the other is the Auto cure. By the former system the sides after being dressed and cooled are charged with brine forced into the flesh by means of hand or machine pumps. It is then salted, piled up, turned and rubbed from day to day for about 11 or 12 days when it is ready to bale and ship.

By the Auto cure system the sides which are loaded on trucks are run into strong iron tanks. These are hermetically sealed, the air pump applied and as far as possible a vacuum created inside. The tank is then filled with the curing solution under strong pressure which forces itself into the flesh filling veins, pores, etc., completely. The sides are left in this condition for 8 to 9 hours when the brine is run off and the air slowly admitted after the pressure has been reduced. Half an hour later the cylinder is opened the meat wheeled out, stacked up to drip for a day when it is baled ready for shipping. While this system saves times and labor it is not growing in favor for the reason that the British merchant finds the bacon thus cured shrinks more than that cured in the usual way. 


\section{A Private Slaughtery.}

The commission visited a private factory at Aarhus that slaughters 20,000 hogs a year half of which arrive by rail. Many come from a section where a co-operative plant was soon to go up, which would materially reduce their supply. This firm is an old established one with a good trade in England. They do their own selling and thus save commission fees. They have buyers going about the country paying them one kroner (27 cents) per hog for buying. All No. 1 hogs in good condition are bought by live weight, while lame ones and those in doubtful health are bought by dressed weight. These are earmarked for identification, and losses in those found to be diseased are borne by the feeders. On July 15, this firm was paying 35 kroner per $110 \mathrm{lbs}$. live weight (about $\$ 8.50$ per $100 \mathrm{lbs}$.) and 50 kroner per 110 lbs. dressed weight (about $\$ 12$ per $100 \mathrm{lbs}$.) This was about 20 cents more per $100 \mathrm{lbs}$. dressed weight than the co-operative factories were quoting to be paid as cash. The private owners publish their quotations in newspapers.

Rail hauls in Denmark are short, 8 hours being the longest time hogs are on the train. Losses during transit are very rare there having been only two pigs shipped to this company die on cars in 1909, up to July 15 . Buyers are cautioned to handle the hogs carefully and not to crowd them in the car.

The proprietor gave the commission a few notes on their system of curing. Both the brine and dry salt methods are used. When thoroughly cool the sides are charged with the usual curing solution by pressure, the same as in Canadian packing houses before being put into brine or salt. The sides remain 5 days in brine or 10 days in salt. When cured the sides are shipped in bales to the representatives in England or Scotland.

\section{The Health of Danish Swine.}

The Danish Government has applied vigorous measures for the protection of the health of live stock. The prevalence of tuberculosis discovered to exist amongst herds of cattle and swine many years ago led the practical Dane to grapple with the question. 'Through the work accomplished the name of Professor Bernard Bang has become a household word the world over, in connection with the subject of tuberculosis. The "Bang" system of ridding herds of this disease is recognized as highly practical. It has done much to improve the dairy industry of Denmark and is being applied with gratifying results by certain breeders in most progressive live stock countries.

Swine raising in Denmark, is carried on as an industry secondary to that of buttermaking. The butter is made in creameries and the milk returned to the farms for feeding to pigs. It being recognized that tuberculosis is transferred from cows to pigs, through the feeding of milk, a law was enacted requiring the heating of milk before it leaves the creamery. On this question Prof. Bang said:-

"The most important of all the measures against tuberculosis among cattle and pigs which have been carried out in Denmark is the law relating to the heating of skimmed milk and butter milk to $176 \mathrm{deg}$. Fahr. before it is returned from the dairies. As in Denmark nearly all milk not sold directly for consumption is sent to co-operative dairies it is clear that there is very great danger of a wide dissemination of tuberculosis if raw skimmed milk and butter milk are returned to the suppliers, to be used as food for calves and pigs. There will always among the suppliers of a dairy be one or more farmers who have a highly tuberculosis stock, one or more cows which yield in the course of the year great quantities of infected milk, and so, by employing this milk, after it has been skimmed, to feed other stock, the infection is spread to hitherto healthy herds. This was formerly done on a large scale, and there is no doubt that most stocks of cattle and pigs in Denmark would gradually be infected in this way. if measures had not been taken to prevent it. Of course the heating of the whey ought to have been enforced by law as well; this was proposed but the proposal was not accepted, chiefly because the heating of the whey is rather troublesome. It is, however, to be hope that this measure will be carried out some day, though 
as whey is mostly used for feeding pigs, it is not so important as the other dairy products, as regards bovine tuberculosis, and besides, cheese-making is not nearly so considerable in Denmark as butter-making.

"In Denmark the observance of the law regulating the heating of skimmed milk is controlled by the police as well as by the margarine and butter inspectors, who procure samples at the dairies and send them to the laboratory of Prof. Storch, where they are subjected to his colour test, which consists of pouring a few drops of paraphenylen-diamin and peroxide of hydrogen into the milk. The milk turns blue, if it has not been heated to 176 degs. Fahr. Offenders against the Act are fined. On the whole, the regulations governing the heating of milk are fairly scrupulously carried out, though of course, there are exceptions. The best plan would be for one or two of the suppliers of each dairy to apply the above easy and simple test every day. This is done in some places and has produced very good results.

"One useful provision of the Tuberculosis Act is that the sediment deposited on the bowl of the cream-separator, is to be burned, which is no doubt always done now. In old days this product was now and then used as food for pigs, and thus many pigs were infected, as it contains enormous masses of tubercle bacilli which are separated from the milk by the centrifugal force."

In Denmark as in Canada, infected hogs are not all condemned. A small proportion of infected carcasses are found quite unsafe for consumption and these are destroyed. A larger proportion, though still quite insignificant, show only slight infection and this confined to a part that can be removed. In such cases the uninfected parts are used for local consumption. Through the operation of the law compelling the pasteurizing of the milk, and the general care taken to safeguard the health of swine, 95 per cent of Danish swine are entirely free from tuberculosis. From this class and this alone are the exports to the British market made up.

The losses from condemned hogs, and portions, are divided between the Co-operative associations and the producers in the proportion of 75 per cent to the Association and 25 per cent to the producer. As already pointed out each pig is ear marked with a metal tag when delivered, by which it is traced. When a pig is condemned a circular of notification is immediately sent to the producer. The Commission was advised that the private factories get a larger percentage of tubercular hogs than the co-operative houses. The manager of Frederickssund co-operative factory assured the Commission that out of 110,000 hogs slaughtered during the last two years not one carcass was totally condemned. Veterinary inspection costs co-operative factories about $\$ 1.65$ per 100 pigs handled.

\section{Conditions in Denmark Reviewed.}

Danish farmers have for many years depended on the hog for necessary revenue. While continental markets were open for live hogs, and paid good prices for pork products, there was no incentive to produce a special type of pig. The closing of Germany against live hogs from Denmark compelled Danish farmers to seek a new market. This they found in Great Britain. An investigation revealed that highest prices were paid for what was known as Wiltshire sides. It was discovered also that milk feeding was favorable to the production of a high quality of bacon.

Co-operation had already proved its value in the dairy industry. It could do so in swine husbandry. The Danish farmer industrious, persistent, and well educated, undertook the task of preparing his pigs for the highest priced trade. The Government recognized the possibilities of the swine industry and was ready to lend a hand to the work. Breeding centres were assisted for the developing of improved seed stock; co-operative pig breeding societies were organized for the dissemination of good blood at little cost, experiment feeding stations were set in operation to solve the question of econmical feeding. Through these several agencies the pigs on Danish farms have been brought up to a high standard. In the early period of the bacon industry co-operation 
was applied to curing and marketing until the entire agricultural fabric has assumed great strength. Commencing with the breeding stock it extends through the rearing of the pigs, the curing of the bacon and the securing of full market values in Great Britain. The work all through is conducted with energy and intelligence. Harmony apparently prevails all along the way with the result that the whole work is constructive. Things that are useless are lopped off, those of doubtful value eliminated or improved, while all that is good is cultivated and encouraged. The Danish official is apparently never satisfied with present conditions. To press forward has been his motto from the first and his ambition has not been dulled.

Constantly growing revenue from the hog has been a strong incentive to the man on the farm. In planning his rotation the Danish farmer remembers the pigs and grows what will best suit that branch of his operations. He has skim milk and has studied its value in pork production. He has learned the correct quantity to feed for best results for pigs of different ages. He combines his foods and prepares them to reap the last cent of profit. Through the co-operative curing organization he pays an expert to look after the convertion of his pigs into bacon and of bacon into money. He pays for having these things done, he does not worry about them but devotes his energies to cheap production of the class of pig that brings him the most money. The bacon industry of Denmark might be compared to a well conducted departmental store having a competent manager in charge of each department. The success of each branch is the success of the store which in the case in question is the Danish swine rearing industry. 


\section{HOLLAND.}

The country of dykes and windmills is largely devoted to dairying and is consequently an extensive producer of pigs. England alone, in 1907, imported from Holland about 170,000 cwts. of butter and 241,500 cwts. of cheese. To consume the skim milk and whey pigs are reared and fed. Being situated in close proximity to Germany the major portion of Dutch pig meats go to the cities of that country in the form of fresh pork. England too, gets some of this and during recent years considerable attention has been given to the production of bacon for the British market. On the London Smithfield market the Commission saw large quantities of both fresh pork and bacon from Holland. Statistics show that in 1907 England received more than 20,000 cwts. of bacon and nearly half a million cwts. of fresh and salted pork, chiefly fresh. Directed by the firm of Mills \& Sparrow, large handlers of Canadian as well as Dutch bacon, the Commission made a short visit, on the return journey from Denmark, to a district of which Oss is the centre. At this point one of the four large bacon curing plants in Holland, is operated by Messrs. Hortag. The four factories are all owned by private firms. 'Their annual killings amount to about 100,000 . During the winter practically all are sold as fresh pork, while in summer it is chiefly cured, but this depends on the relative values of fresh pork and cured bacon and pork. The farmers pay comparatively little attention to the market end except in so far as the packing firms dictate. When the packers want light, young pigs for the fresh pork trade, they quote higher for this class than for older stock. When the bacon trade promises to be more profitable farmers are encouraged to hold their pigs until 6 to 7 months old and reach bacon weights. No attempt at co-operative curing has been successfully made. In view of the undecided state of the industry Holland need not, for the present at least, be considered a strong competitor of Canada in the bacon market.

The factory at Oss in winter, kills from 2,000 to 3,000 hogs a week for the export trade. In July, 1909, the firm was killing about 1,000 per week chiefly for bacon. This was about half the number usually killed at that season. The shortage was said to be due to dear food stuffs. During the first half of 1909, this factory had sent to England bacon from 10,000 pigs and 20,000 small pigs (about 100 to 120 lbs. dressed) as fresh pork.

Dutch farmers are following to some extent the methods of the Danes in the matter of pig breeding. To improve the stock five breeding centres have been established. These are chiefly stocked with Yorkshires but there are a small number of Tamworths as well. The object of the centres is to produce good boars to improve the native stock. The native sow is a white. fined-boned animal of medium length. Her offspring at 4 to 5 months old are well adapted to the fresh pork trade. The introduction of the Yorkshire and Tamworth is to improve the pigs, from the bacon standpoint.

In the neighbourhood of Oss the farmers cook all pig feed. At each place visited was found a large kettle set over a brick fireplace for cooking food. The food used consists of potatoes, barley, rye and buttermilk. Feeding is done three times a day frequently by women who take a keen interest in the stock. All pigs seen were very thrifty and well grown. A lot of six said to be only 20 weeks old would weigh about $180 \mathrm{lbs}$. each. These were getting a thick slop made of buttermilk and ground barley fed warm. As pigs approach the finishing stage roots and potatoes are almost if not quite withheld from the ration.

The factories quote prices weekly and take all that are fat enough. In July, 20 per cent of the receipts were too small for bacon and were sold fresh. Eighty per cent were being cured as Wiltshire bacon for the English market. Buying is done much the same as in Canada. In some districts one buyer is paid a salary and he has three or four men who buy for him on commission. The pigs are bought at the farms and paid for according to live weight on delivery at the railway station or packing house. 
Like Canada and other progressive countries, Holland has a meat inspection law by which Veterinary inspection is applied to all slaughter houses killing animals for export. To cover losses on pigs condemned farmers pay an insurance of about four cents per hog. which, when pooled by the packing firms, about covers the losses which are chiefly due to tuberculosis. This tax is imposed in the form of a deduction from the purchase price of the hogs. It may be stated that in Canada this principle is applied to a limited extent with satisfaction in the buying of certain classes of cattle. It might well be applied in the buying of hogs.

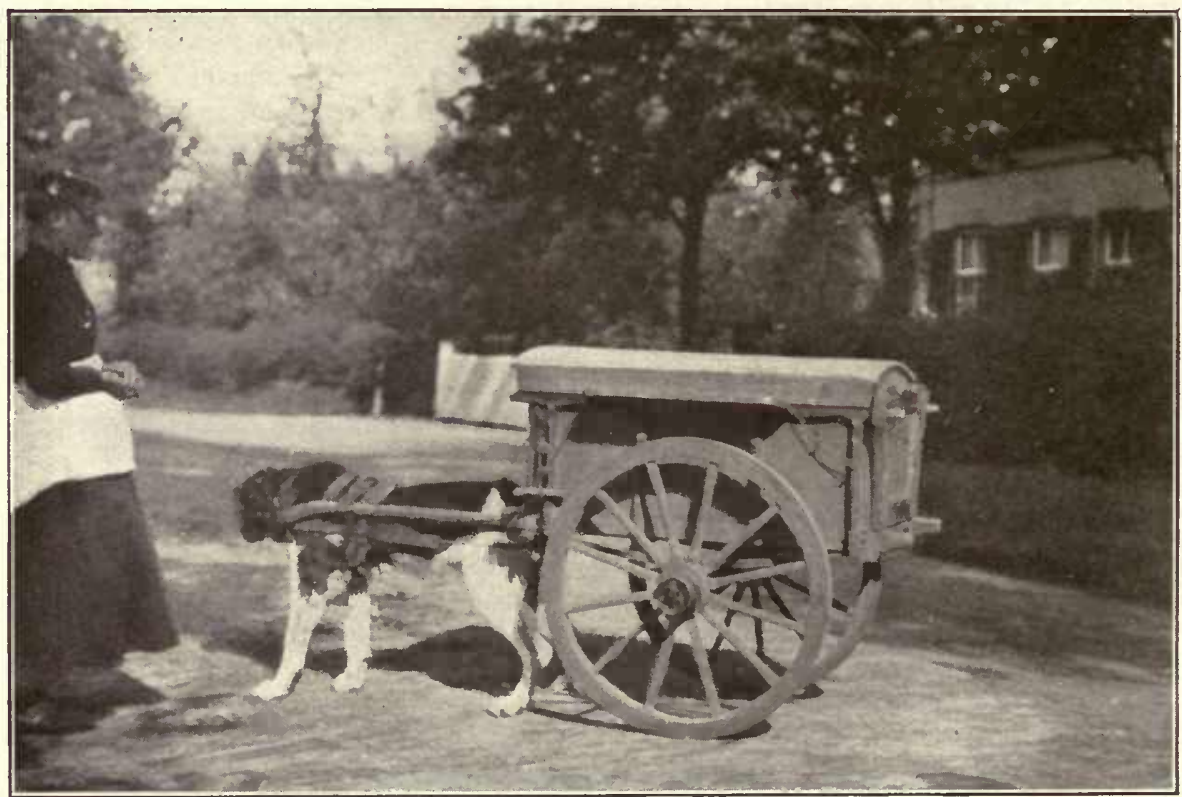

A Method of Transportation Common in Holland. 


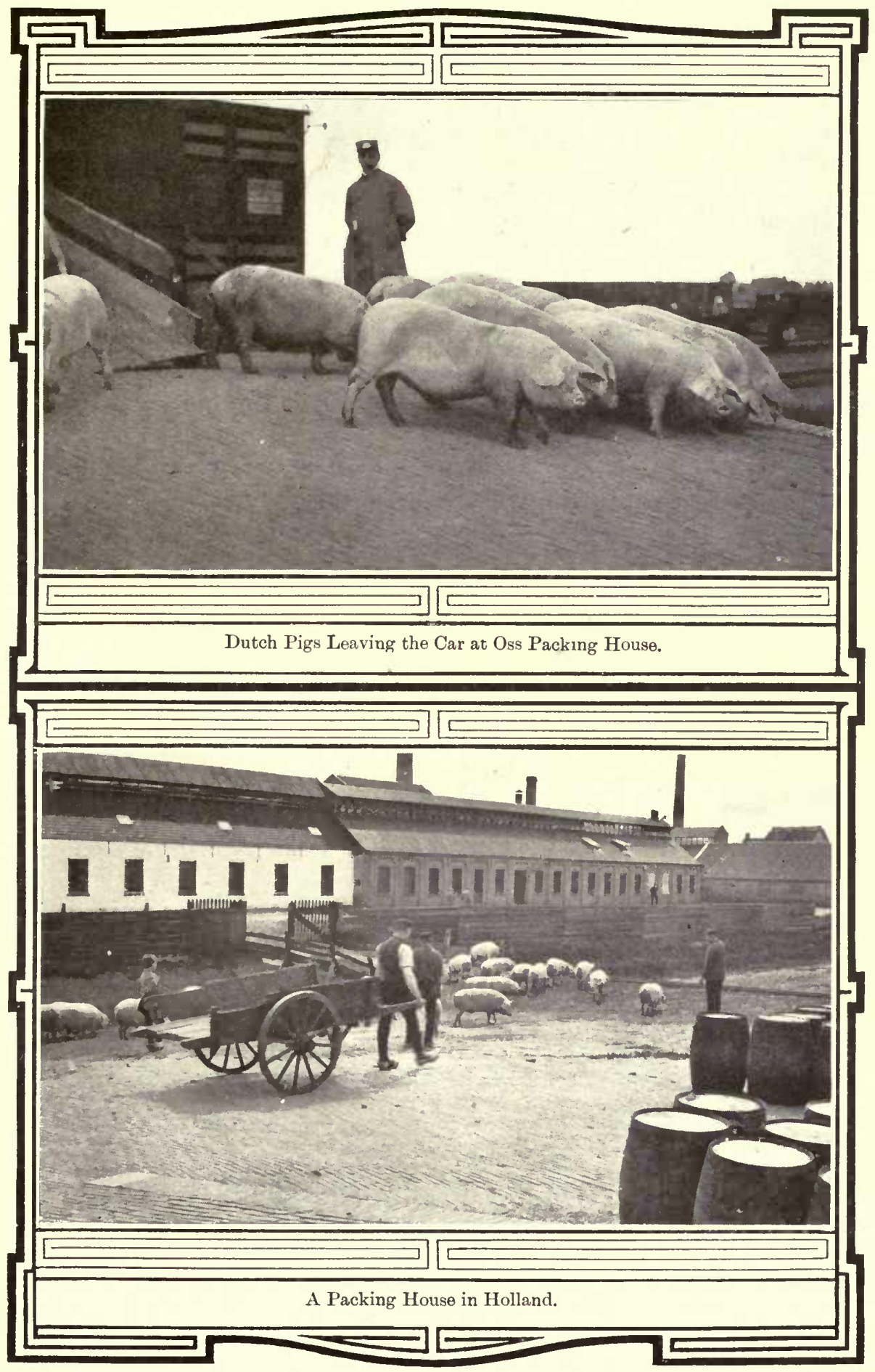





\section{BACON IN ENGLAND.}

The Commission called upon a number of firms in London and Glasgow who handle Canadian, Irish, Danish and other brands of bacon. Without an exception dealers spoke favourably of Canadian bacon. The finish and shape of the sides of Canadian are satisfactory. In these respects Canadian sides lead others. Both Danish and Irish sides are less carefully scraped and trimmed, and the former carries a bit more waste at either end. The Danish side carries the leg bone down to the hock and knee, while the Canadian is cut higher up. 'The Danes also leave on as much as the market will stand of the jowl, whereas in Canadian the head is cut off squarely.

Canadian bacon was claimed to have shown a slight deterioration during the past three years. While supplies were heavy packers were more careful to keep back light and soft sides. The great shortage is leading them to put in many unfinished sides. Ideal weights of sides are 48 to 70 pounds, but much Canadian runs from 42 to 44 pounds per side. These light sides are dubbed 'skin and grief.' The chief complaint expressed was the serious falling off of Canadian supplies.

A few years ago Canadian bacon established an excellent reputation, and trade was growing satisfactorily. Had the supply kept up it is difficult to estimate the magnitude of the trade that might have been reached even now. One firm that in 1903 was handling from 300 to 900 boxes of Canadian weekly, had dropped, in 1907, to 200 to 400 , and in 1909 to 117 to 186 boxes per week. Other firms report a similar decrease. The result is that customers have to be supplied with Dutch, Russian, Danish and other makes, and where they get satisfaction in using these they cease to ask for Canadian. Canadian bacon has, therefore, during the past few years lost much ground that would be difficult to regain.

The quality of Canadian bacon is satisfactory. It is not nor cannot be equal to the Danish, on account of the harder cure that is necessary to keep the meat during the longer journey. In three days after Danish bacon leaves the curing cellar it is ready for the smoke house, and two days later it goes on to the counters of the retailers. Canadian, on the otler hand, requires 14 days in transit, and this demands the harder cure. The taste of the British consumer is the same for bacon as for butter. It prefers mildness of flavour. Again the stronger cure of Canadian imparts hardness which is even more objectionable than a little extra salt. Danish bacon cuts on the plate almost like fresh pork, while Canadian has a tendency to break under the knife. This difference that cannot be overcome gives Danish a slight advantage in price, but there is room for both as all do not demand the mild flavour. Canadian curers have, from time to time, endeavoured to overcome the difference and have lost boxes of sides that were undercured. By the use of a light application of borax before shipping, strength of cure has been reduced, and this has its own objectionable features. While Canadian and Danish bacon differ in the degree of cure and other minor features, they are stronger rivals than Irish and Canadian. Irish bacon to a large extent has a field of its own. It enjoys a popularity earned many years ago, and rather than risk loss through undercuring the Irish curer adheres to a fairly strong salting. In a test of disguised samples of Canadian, Irish and Danish bacon selected by an experienced London dealer, the sample which proved to be Danish was unanimously voted to be best, Irish next and Canadian last. Mildness of cure, tenderness and flavour were the qualifications observed. It is claimed, and on good ground, that the tenderness and fine flavour of Danish bacon is, to a large extent, due to the rapid growth of the pigs and the universal use of milk in feeding. English Wiltshire curers know the value of milk in imparting quality, and their buyers have regard to this when selecting hogs throughout the country. 
Canadian bacon is practically all consigned to commission firms, to whom the wholesalers look for their supplies. Some Danish, on the other hand, is bought in Denmark direct from the packing houses. The bacon is shipped f.o.b., the English buyer taking the risk. In the case of a small number of factories in the north of Denmark the bacon is sold through a representative. Some 5 or 6 factories finance the salesman, allowing him 30 days time to remit returns. The salesman gets a salary of about $\$ 10,000$ a year. At the end of the year accounts are squared between this man and his several factories.

As already pointed out much Danish bacon is purchased direct from factories by English buyers. By careful grading and honourable dealing the Danish salesmen have the full confidence of the English merchant. The former ships nothing but good stuff. 90 to 95 per cent of sides grading No. 1. The Danish system of selling throws much of the risk of deterioration on the English buyer. This is an important item, as in warm weather the meat goes off very quickly on account of the mild cure. It can be held a few days in cold storage before smoking, but this is not satisfactory as it beromes dull in appearanre and soon goes off after being taken out. Danišs bacon held one week in mild weather deteriorates about one dollar per cwt., and if held a few days longer it is unsaleable and meets condemnation by the food inspectors.

Canadian bacon is shipped in boxes, about ten sides to the box, while Irish, Danish and other continental go in bales, four sides to the bale. On arrival in England after reaching the wholesaler, Canadian is washed with a rough brush and abundance of water. This is to remove the borax. It is then allowed to drain four hours before going into the smoker. Other kinds of bacon do not require washing, but go direct to the smoke house. This washing is an extra tax on Canadian bacon on account of the labour it entails and because of increased shrinkage. Before going into the smoker all bacon is coated with finely ground pea meal. The smoking is done with wood smoke. The process requires 36 hours. The smoking causes shrinkage in weight. In the case of Canadian this, when added to other expenses, costs 5 shillings per cwt. (112 lbs.) In the case of Danish the cost, including shrinkage, is only 3 shillings per cwt. (112 lbs.). The actual shrinkage in weight in the smoking is for Canadian 3 lbs. $13 \mathrm{oz}$. per side; Danish $2 \mathrm{lbs} .4 \mathrm{oz}$ per side; Irish 2 lbs. $4 \mathrm{oz}$. to $2 \mathrm{lbs} .12 \mathrm{oz}$. per side. These figures are for sides 56 to $60 \mathrm{lbs}$. each.

The above criticisms and comparisons of bacon from different sources were given by some of the largest handlers in the British Empire, and verified by many smaller dealers. One firm quoted, that of Bowls, Nichols \& Co., does a yearly business in bacon of about $\$ 2,000,000$, while J. Wheeler Bennett, Sir Alfred Reynolds and Mills \& Sparrow deal on corresponding scales. These firms lament the decline of the trade in Canadian bacon, which promised so well. While all agree that Danish and Irish have natural advantages over Canadian, they pointed out that the securing of a big end of the English trade depends more on regular supplies than upon any improvement in quality. Canadian bacon is popular and sells well, usually a slight margin below Danish. 
Selling Prices of Canadian and Danish Bacon in England.

The following table shows the actual selling price in dollars and cents per 100 pounds in London of Canadian and Danish bacon, grade No. 1, from month to month from the beginning of April, 1904, until the first week in December, 1909 :-

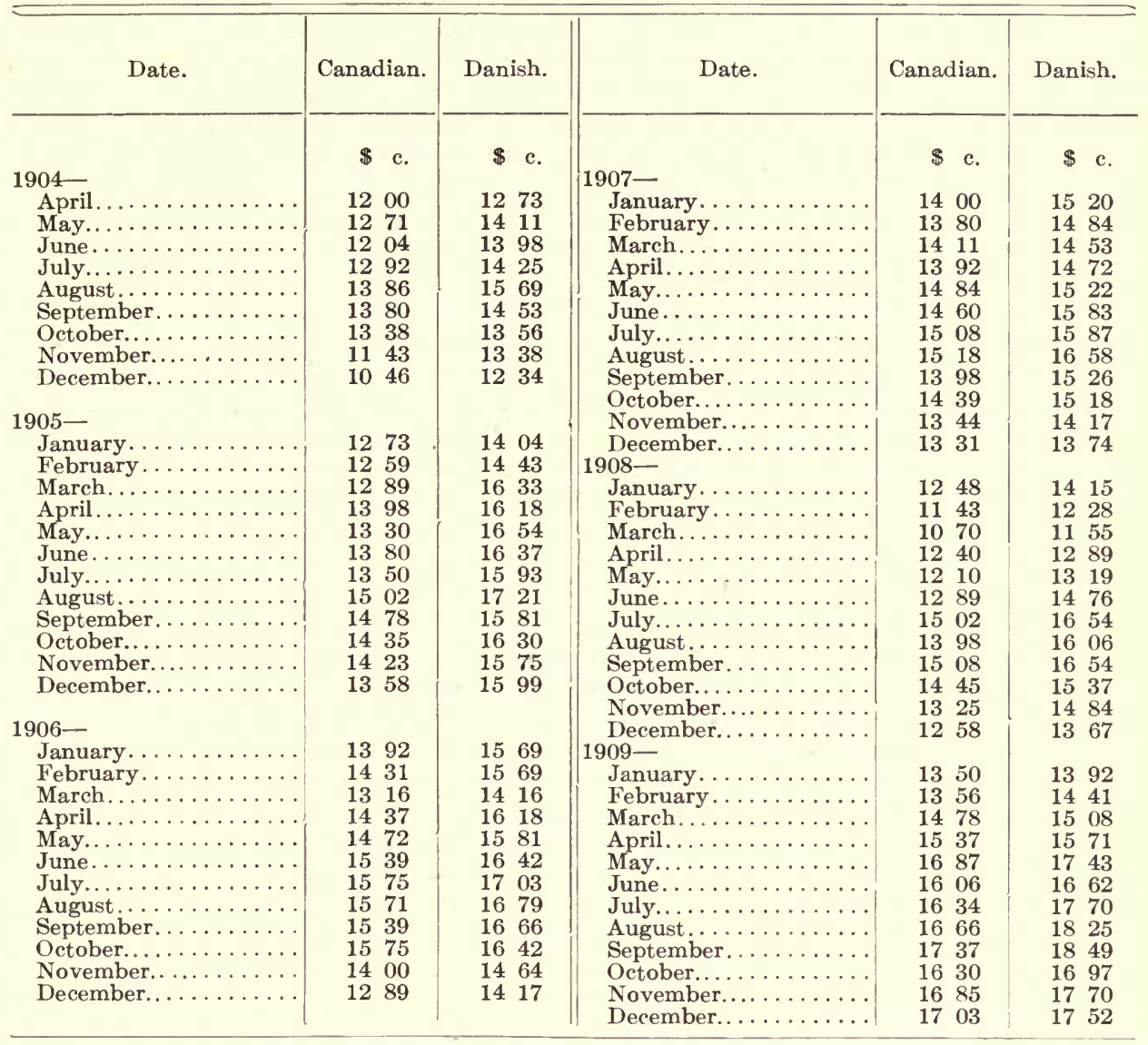




\section{LESSONS FOR CANADIAN SWINE RAISERS AND PACIKERS.}

The commission, composed of farmers residing in various provinces of Canada, who rear and market swine in greater or less numbers each year, started out with a clear understanding of the various phases of the swine rearing industry throughout the Dominion. The instructions given them to investigate and find out as far as possible the conditions responsible for the success of the industry in Denmark, Great Britain and Ireland were fully comprehended. The Commission undertook this work seriously and devoted their time earnestly to the task. Every facility that could be asked was placed at their disposal. The Commission is prepared to depend on the report to justify its effort.

A careful reading of the various chapters will reveal many lessons on pork production. The time of the Commission was spent among successful men and associations who revealed their methods for examination. Nowhere was there found evidence of success being attained through mysterious methods or secret processes. Intelligent management was found to be responsible for satisfactory results all along the way. This included persistency of purpose and a confidence in the system followed. Everywhere was there found a tendency to intensive methods which demand careful attention to details. Nowhere was haphazard work associated with satisfactory result. Swine rearing as examined in Europe is a highly organized branch of agriculture secondary to and almost always associated with dairy farming.

In Ireland the rank and file of pig raisers are men of small means who have found in the pig a means of converting unsaleable products from the dairy, the potato field and other parts of the farm into a valuable product. Long experience, coupled with frugal habits and need of the returns from the fatted swine, have taught the most profitable methods of feeding. This cannot be said to be done by any special system, but rather according to the circumstances of each case and the judgment of the feeder begotten through long experience. 'The average Irish pig feeder is quick to detect evidence of unthriftiness in his pigs, and sharp to apply the remedy. He does not overstock, but keeps sufficient to use to best advantage the offals and by-products he has, together with as little as possible of expensive food. He keeps on day after day and year after year in raising swine, and this is perhaps the most important lesson he has for the Canadian farmer. By this persistence he has done his part in bringing the Irish bacon trade into a profitable industry for Ireland and the individual Irish farmer.

In England the conditions are different. All agriculture may be said to be carried on by an intensive system. While as in Ireland no suitable by-products are allowed to waste for want of pigs, the industry goes farther than this, amounting even to an important branch of a highly organized system of live stock husbandry. The keeping of pigs is carried on as a business enterprise and no chance is taken in regard to the losing of money. Much of the concentrated food used is purchased at high prices, and the books in the pig account must show a profit. There is little chance to save in the price of food, which leaves the profit to be made from the pig side. The employment of a bright, experienced feeder kept under the watchful eye of the master, is the means adopted in getting results from the foods consumed. The English farmer, too, is stable and consistent in his system of farming, and this has given him experience and established a reputation for his products. He has a valuable lesson for the Canadian in his consistency of purpose, application and keen business principles.

The Scots farmer does not make a specialty of pork production. He milks cows and makes cheese and uses pigs to turn the whey to good account. He buys most of his grain food and must exercise care to get back his money with a little profit and something for the whey. He has studied how to get these, and follows intelligently what he has found to give best results. Having learned that sweet whey is better feed than sour, he gives it as fresh 
as possible and avoids, as a principle, feeding a larger quantity than experience has taught to be economical. The feeding is done with every care and regularity, usually by the same person. The Scots feeder would teach the Canadian cheese factory patron that there is profit in the intelligent feeding of whey in sweet condition to pigs from store to finished weight.

The industry as conducted in Denmark has lessons for the Canadian pig raiser all along the way. The top place in the bacon trade of England has been the goal in view, and the energies of the Government, the pig breeder, the pig feeder, the curer and the seller, all point in the one direction. As one man all interested in the industry pull together and every branch separately works for perfection of the whole. The pig raiser wants only bacon pigs, and these as prolific and good as possible. The feeder, with his eye constantly on the grade his pigs shall ultimately reach, studies to gain this from the least outlay for feed. He does nothing by spells and spasms, but finds the road and persists in following it. Judgment born of successful experience keeps his day to day practice right, and as a pig raiser he succeeds. His conditions are not unlike those of the Canadian farmer who follows dairying, except that he has more feed to buy on account of his limited acres. He is succeeding because he will keep only such pigs as are good mothers of vigorous litters; in feeding them only on such foods and in such a manner as he knows gives greatest ultimate profit; in observing the demands of the market upon which the size of his pay cheque depends; and by his confidence in his own efforts and those in charge of the other branches of the industry.

Everywhere the ideas of pig feeders agree with those of the most successful Canadians in regard to the best age to wean litters. Nowhere were breeders found weaning at less than six weeks, and most breeders leave the litters on the sow until two months old.

Both in Denmark and Ireland the results of feeding experiments agree with those carried out at Canadian stations in that the cost of gain per pound increases with age and live weight. In Denmark especially it is confidently believed by feeders that hogs that are kept thrifty and growing from the time they are weaned until ready for market at five and a half to seven months old, weighing about 200 lbs., are more profitably fed than those given longer time to finish or carried to heavier weights.

The value of milk and whey in pig feeding was everywhere exemplified. The Commission saw very few pigs being fed without one or the other, and nowhere were these foods fed without a care for the greatest profit.

Roughage in the form of roots or other green fodder is considered an essential part of the successful pig raiser's food supply. These, it is generally believed, help materially to maintain thrift in breeding and growing stock. Nowhere can these be cheaper grown than in Canada and no pig raiser can afford to be without them.

Another lesson gathered in each country visited is the importance of carefully grading the ration according to the age of the pigs and the object in view. Everywhere young pigs were fed on easily digested food rather light in character and with only a small percentage of green food. As the pigs get older roughage is increased to cheapen the ration and strengthen and keep in tone the digestive organs. As the finishing approaches the ration is made stronger which hastens the fattening and assures a high quality of meat. A study of the feeding throughout the report will impress this important lesson.

\section{The Marketing End.}

The members of the Commission are aware that many Canadian farmers understand well the economical production of pork, They are also familiar with the cry of a large number who claim that they cannot make pig raising profitable even at the high level at which prices of hogs have been maintained during the past two years. This, however, does not fully explain the gradual serious decline in the production of hogs that has for some time been going on, more especially in the province of Ontario, on which the export bacon trade chiefly depends. Another problem than that of feeding confronts the Canadian pig raiser. Between the feeding pen and the market there is a great gulf fixed and to bridge this most concerns the pig raisers. The Commission hear it in their respective neighborhoods, the 
market places, the institute meetings, the winter fairs, in fact wherever farmers congregate to discuss their industry, that the bacon industry has no stability, and that the producers do not receive their share of the returns from the market. In the face of this we have the continuous high prices that have maintained, not in the summer alone when values are almost always high, but right through the autumn and into the winter even at the holiday season when so many householders are expected to be using poultry. But, say the great army who have sold their sows "What would have happened had we all continued raising hogs at the rate of 1903 ? allow the supply to reach a high point and the great gulf is ready to yawn at us as ugly as before. We are getting along very well without the pigs. Satisfactory help is not easy to get and our calves, foals and fowls are making very good use of the skim milk." This is the feeling that is experienced throughout the country and enables the wise, persistent hog raiser to make a fine profit from his swine.

Then there is the grievance about buyers paying at the flat rate for all kinds light, ideal and heavy. Much pains have been taken to produce the long, fleshy singer which brings the producer no more than the cheaper fat pig that is produced in the corn belt. The packers again get the credit of reaping the fine returns from the superior hogs after purchasing them at the same rate as the less valuable kind. The packers blame the buyers and the buyers keep on as they have been doing while no concerted effort is being made to bring about a satisfactory solution of the problem. The farmer is following his inclination but what is to become of the bacon industry?

In Ireland, in England and in Denmark, the Commission compared this with the state of the industry which in those countries was found to be sailing upon a comparatively smooth sea. It is true that producers and packers in the Old World, have not always seen alike and even yet troubles and doubts arise. Each country in its own way, manages to solve these problems, not by dropping the industry but by discovering the weak points and applying what appears to be the best remedy. In some cases the packers have taken the initiative in others it has been left to the producers. In England we have examples of both. 'The Harris Wiltshire curers allow no grievance to grow. With the least evidence of dissatisfaction the farmers are asked to meet the packers to examine for themselves the point at issue. Such meetings are not confined to interviews in which the books are revealed to prove a theory but the whole question is thrashed out until confidence and harmony are restored. The packers in this, exercise good business judgment as they know well that their success depends on the supply and kind of hogs they are able to get from week to week and from month to month. Co-operation between the two is alike good for the packer and the producer.

In the Eastern counties co-operation works out in another way. The buyer became a dominating factor and having no important business at stake he undertook to take more than his share of the returns of the industry. The impression gained foothold that an understanding between buyers had been reached but this did not drive farmers out of pig raising. The Eastern Counties Farmers' Co-operative Association engaged an experienced salesman and trusted him to find a market. This man drives an automobile up and down the roads and farmers are so well satisfied with the results that they raise in that district more pigs than anywhere else in Great Britain.

In Ireland the Commission heard some grumbling about the buyers. The pig fair system of selling is not quite satisfactory. Buyers usually arrive at the town the evening before and it is felt that competition is not always as keen as it ought to be. Here, however, buying on merit is the rule for every bunch of pigs calls for a long discussion and the good pigs got the preference. Then the old established packing firms announce their prices for first-class hogs and usually set it high enough to get most that are offered.

Still some dissatisfaction with conditions of buying hogs prevails in Ireland and it is confidently predicted that unless co-operative curing becomes general in parts of Ireland where pigs are sold alive, that it will not be long before auction markets are operated as in England and Scotland. This it would seem should be a good solution for much of the buying difficulty in Canada. It ought to do away with the flat rate system of paying alike for all kinds, good and bad. It would do more, it would stimulate competition which is limited to a minimum in many country sections in Canada. 
Co-operation is, however, the best solution as indicated in Ireland and Denmark. The members of the co-operative bacon factory at Roscrea are satisfied with their lot as pig raisers looking for full returns from their hogs. Between them and the market there is nothing to obstruct the vision and there is no one to blame but themselves if the prices received are not those quoted for the highest class.

In Denmark the industry has grown rapidly and substantially and is thriving as a well watered tree in good soil and all on the principle of co-operation. Co-operation in Denmark had its origin in dissatisfaction with the packer and on its own success it continues to bring prosperity to the pig raiser and contentment to the farmer.

Co-operation in Canada can it succeed? Some say 'no, it has been tried and failed.' was it not a poor kind of co-operation that failed? The intention of organizers was of the best. much hard work was done, farmers put in a lot of money and well equipped factories were put in operation; business connections that promised well in the Old Country were made and co-operation in the bacon industry was launched, but it did not last. Where was the weak point? It was not in the hogs for there were plenty and of good bacon type; it was not in the factories for these have proved their own success in the hands of proprietory firms; it could not have been the market for this has never ceased to grow for the Danes and others who send on the good bacon in regular quantities. Was the system of co-operation defective? It would seem so, at least for the disloyal members who soon commenced to bite at the dangerous bait of rival houses who received every encouragement to cast their bread upon the waters, to be gathered in larger loaves in the not too distant and very certain future. No, co-operation did not prove a success in the pig business nor could such a brand of it have succeeded in any business in which it might be tried. It would have as surely failed in Denmark with such poor staying material. The early organizers in that country saw the rocks ahead and added a penalty clause to the rules. It required only a little patience and honour to teach the Dane that co-operation was the correct method and since then it has proved not only to the Danish but to the Canadian farmer as well, that wisely conducted co-operation is a sound principle.

The failure of co-operative bacon curing in Canada, has valuable lessons. The success of the system in Denmark and in Ireland, has still more valuable lessons. With the instruction that these impart there should be no need of failure in every attempt at co-operative bacon raising, curing and selling, in districts of a country so well adapted as Canada for the raising of swine. A successful co-operative society requires a strong leader and a faithful membership. Unless a community is made up of such a class, who will bind themselves for a term of years to supply all their marketable hogs to their own factory and stand firmly and loyally by the interests of their organization, it need not hope to make co-operative curing a success. Given such men, with a desire to follow pig raising as an important branch of their agriculture, a co-operative association will work in Canada as it does in Denmark. The initiative must, however, come from the pig raisers and be carried through as a remedy to a grievous situation. Having come into contact with a large class of farmers who are growing rich through co-operative bacon raising the Commission confidently recommends it to the pig raisers of Canada who will do their duty towards it.

\section{Suggested Remedies.}

Realizing the conditions which called for the appointment of the Commission and having studied the methods of successful pig raisers in other countries, the Commission submits the following alternative remedies for what appears to be the chief barriers to a prosperous swine rearing industry.

1. The adoption, on the part of the packers, of an attitude of sympathetic co-operation between themselves and the producers whereby every possible encouragement would be given farmers to increase the quantity and improve the quality of their hogs. This would involve a constant, earnest desire and readiness to afford every facility on their part in cooperation with the producers, to investigate and solve problems which may give rise to 


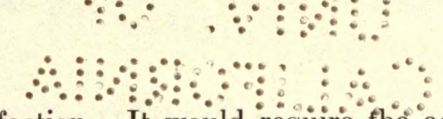

dissatisfaction. It would require the adoption of a careful grading of the prices of hogs through the year, guarding against discouraging low levels. It would require the control of buyers and the recognition of quality in the prices paid for hogs.

2. The co-operation of farmers in engaging a salesman for their hogs, as is carried out by the Eastern Counties Farmers' Association of England.

3 . The adoption of the system of selling swine on the open market as applied to cattle and sheep. By the co-operation of neighbours car loads could be sent forward at regular intervals.

4. The establishment of co-operative packing houses as conducted in Denmark and in Ireland. 
6.



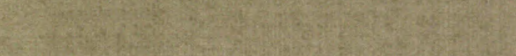



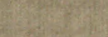

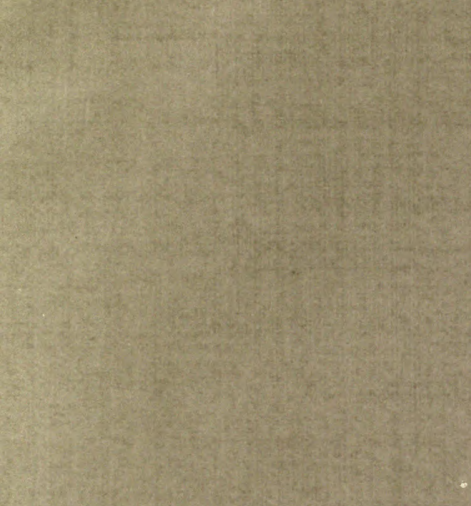

Wel

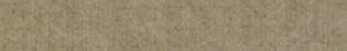

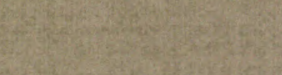

(1)

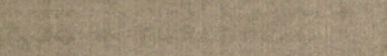

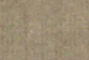

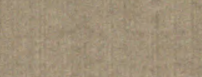

(1)

cats

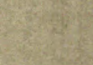

(2)

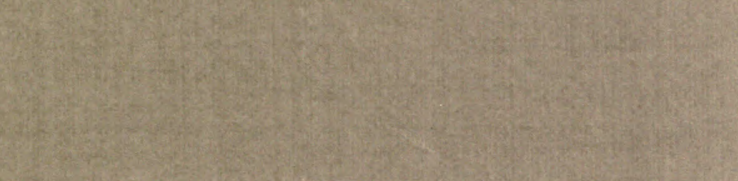



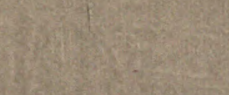

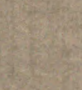

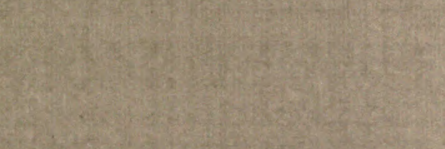
tarit

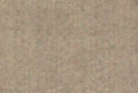

$\operatorname{lin}^{2}$

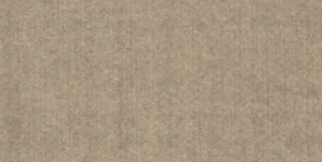

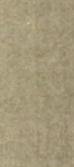

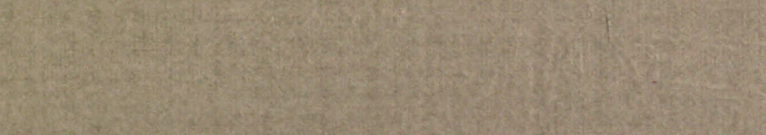

$1+2 x^{2}$

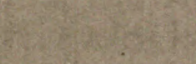

1.

2.

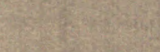

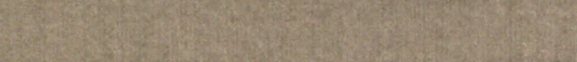

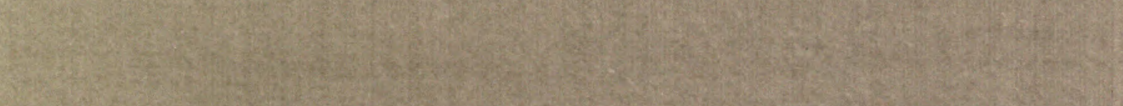

ate

$\cos 20$

(1)

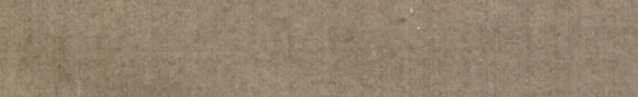



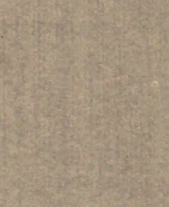

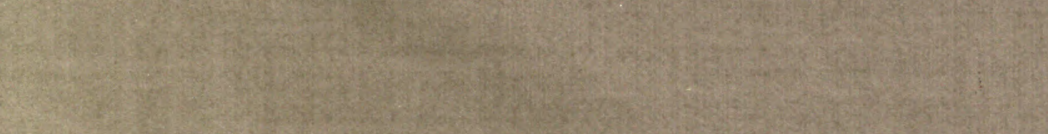

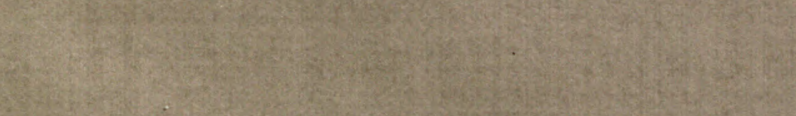

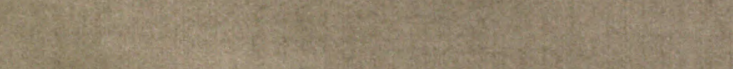

(2)

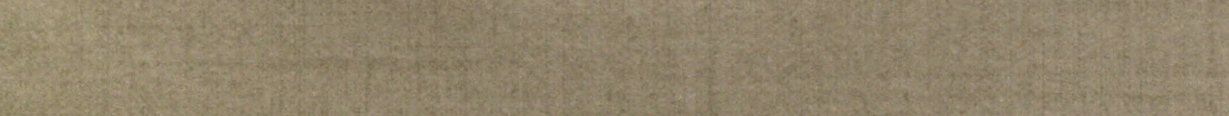




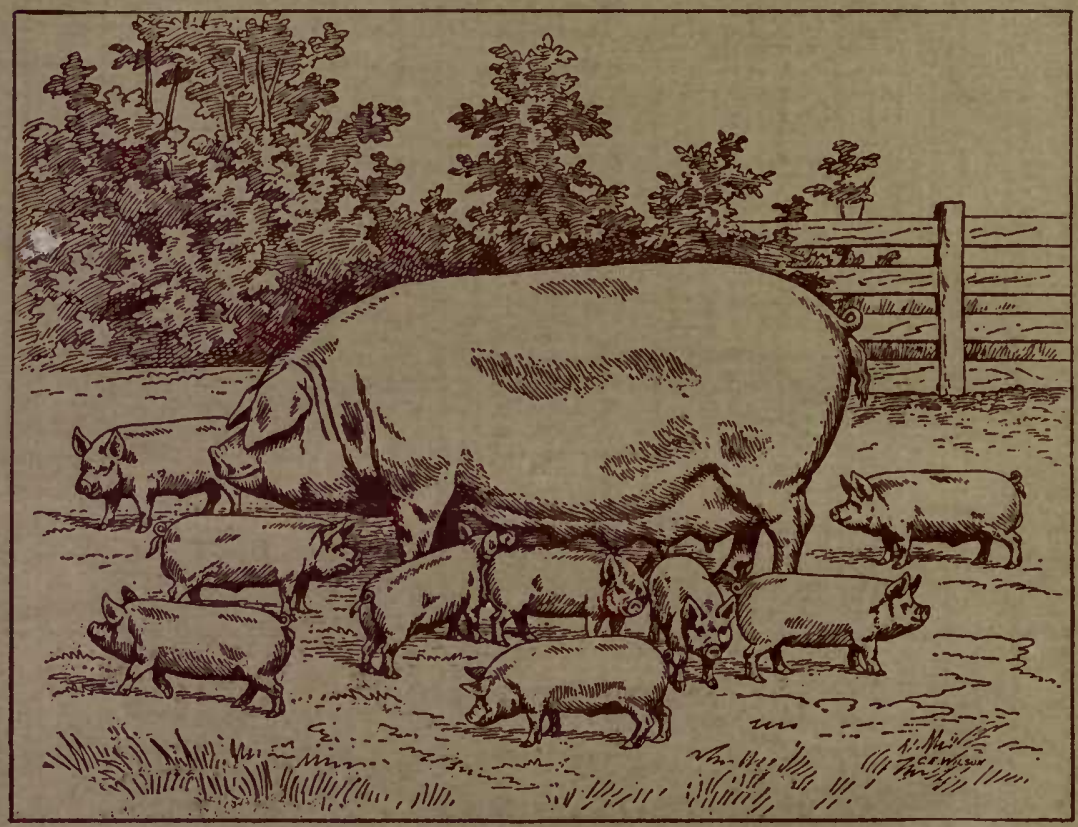








U.C. BERKELEY LIBRARIES

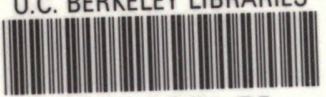

C027500631




